Gisele Gomes Nogueira Alves

Estudos estruturais como subsídio à taxonomia de Simaba Aubl. (Simaroubaceae) 
Gisele Gomes Nogueira Alves

\title{
Estudos estruturais como subsídio à taxonomia de Simaba Aubl. (Simaroubaceae)
}

\author{
Dissertação apresentada ao Instituto de \\ Biociências da Universidade de São Paulo \\ Para obtenção do título de Mestre em Ciências, \\ Área de concentração em Botânica.
}

Orientador: Prof. Dr. José Rubens Pirani

São Paulo

2015 


\section{Alves, Gisele Gomes Nogueira}

Estudos estruturais como subsídio à taxonomia de Simaba Aubl.

(Simaroubaceae).

$95 \mathrm{pp}$.

Dissertação (Mestrado) - Instituto de Biociências da Universidade de São

Paulo. Departamento de Botânica.

1. Anatomia foliar; 2. Taxonomia; 3. Simaroubaceae.

\section{Comissão Julgadora:}

Prof(a). Dr(a).

$\operatorname{Prof}(a) . \operatorname{Dr}(a)$.

Prof. Dr. José Rubens Pirani

Orientador 
Dedico a meus pais, Luiz Tadeu Alves e Sonia Gomes Nogueira Alves 
Eu não sei como devo parecer para o mundo, mas me sinto como um menino brincando à beira-mar, divertindo-me em descobrir uma pedrinha mais lisa ou uma concha mais bonita que as demais, enquanto o imenso oceano da verdade continua misterioso diante de meus olhos. 
Gostaria de agradecer primeiramente ao meu orientador, Prof. Dr. José Rubens Pirani (IB-USP) por ter me recebido como sua aluna, pela fantástica orientação na iniciação científica, continuidade no mestrado e planos para o doutorado; pelo companheirismo e extrema dedicação ao nosso trabalho e pela confiança em me designar um grupo de estudo tão extraordinário.

Agradeço ao Instituto de Biociências da Universidade de São Paulo (IB-USP) que me recebeu e que possibilitou o desenvolvimento deste trabalho. Agradeço também ao $C N P Q$ pela concessão de meu primeiro auxílio financeiro para desenvolver este trabalho e a Fundação de Amparo à Pesquisa do Estado de São Paulo (FAPESP) pelo auxílio financeiro concedidos nos demais meses deste projeto.

Em especial, agradeço ao colaborador e Professor Dr. Diego Demarco (IB-USP) do laboratório de anatomia vegetal do IBUSP, que desempenhou conosco um papel de co-orientação simbólica, me acolhendo como uma de suas alunas e sanando todas as minhas dúvidas técnicas e teóricas, além de demonstrar sempre grande entusiasmo com nosso trabalho.

Ao colaborador, doutorando Marcelo Fernando Devecchi, pela parceria e amizade, pelo auxílio constante no laboratório, com as coletas, e claro, por compartilhar comigo a paixão e entusiasmo pelas Simabas. Agradeço a bolsista Natalie Capelli pelo grande auxílio nos impecáveis cortes histológicos das flores.

À minha família do Laboratório de Sistemática Vegetal (IB-USP): Os professores Renato Mello-Silva, Lúcia G. Lohmann, e Paulo T. Sano pelos ensinamentos, ótimas conversas e convivência; os técnicos deste mesmo laboratório Viviane Jono, Roberta Figueiredo e Abel R. Cangussu e os queridos colegas Alexandre Zuntini, Adriana Alisson Nazareno, Annelise Frazão, Augusto Giaretta, Beatriz Gomes, Benoit Loeullie, Caetano Oliveira, Carolina Siniscalchi, Caroline Andrino, Carolina Agostini, Cintia Luz, Daniela Gomes, Euder Glendes, Guilherme Antar, Gustavo Heiden, Ian Souza, Isabela Akemi, Juan Pablo, Juliana Lovo, Juliana Rando, Jenifer Lopes, Jéssica Franscisco, Kyoshi Beraldo, Leonardo Borges, Luiz Henrique, Maila 
Beyer, Maria Fernanda, Matheus Fortes, Mauricio Watanabe, Miriam Kaehler, Paulo Baleeiro, Paulo Gonella, Receba Viana, Rodolph Sartin, Suzana Alcantara, Verônica Aydos(e todos os alunos que por ventura possa ter me esquecido); Ao Marcelo Kubo pelo auxílio com as pranchas de imagens deste trabalho e à Michelle Thais Sendas pela rápida mas efetiva aula de diagramação das imagens.

À Dra. Juliana Hana El Ottra pela parceria enorme, amizade incrível e valiosas contribuições desde o início deste trabalho e por compartilhar comigo a paixão pelo estudo estrutural das Sapindales. Aos pós-docs Anselmo Nogueira e Fabiana Firetti (IB-USP) pelas incríveis adições ao meu conhecimento sobre ecologia, estrutura foliar, sugestões e auxílios ao longo do trabalho.

Aos professores do Laboratório de Anatomia Vegetal (IB-USP): Veronica Angyalossy, Gregório Ceccantini, Nanuza Luiza de Menezes, e Gladys Flávia Melo-dePinna, e os técnicos Gisele R. O. Costa, Tássia C. Santos e Irwandro R. Pires pela paciência e auxílio em minha jornada de aprendizado neste laboratório, e também aos queridos colegas Aline Siqueira, Caian Souza Karina Bertechine, Fernanda Cordeiro,Giuliano Maselli, Josi, José Hernandes, Keyla Rodrigues, Luíza Teixeira, Marcelo Pace, Mariana Victório, Juliana Brasileiro, Paula Elbl, Rafael da Silva Cruz, Raquel Koch, Mario Albino, Marli Botanico, Marília Duarte, Nelly Araya, Placido Buarque, Renata Lemos, Renata, Thália Gama, Vítor Barão, Yasmim Hirao (e todos os alunos que por ventura possa ter me esquecido) pela paciência e ótima convivência, por me acolherem de forma tão atenciosa; pela amizade e laços incríveis que criamos.

Aos professores de minha banca de qualificação Renato de Mello-Silva, Gladys Flávia Melo-de-Pinna (IB-USP) e pós-doc. Fabiana Firetti, pelas correções e sugestões ao projeto nesta ocasião. Aos alunos, professores e funcionários da UNICAMP.

Aos meus pais, Luiz Tadeu e Sonia, por sempre terem apoiado meus estudos, por entenderem minha atípica escolha de carreira e principalmente, por se orgulharem de mim antes mesmo de minha primeira conquista; pelo amor incondicional e ótimo exemplo de vida que são.

Ao todo poderoso Allan, cuja peculiaridade em me solicitar este tipo de tratamento nos agradecimentos de minha dissertação de mestrado é um dos motivos pelo qual o escolhi para me acompanhar pela vida. 
Resumo ii

Contextualização geral 10

1. A ordem Sapindales 11

2. A família Simaroubaceae 12

3. O gênero Simaba Aubl. 15

4. As seções de Simaba: S. sect. Floribundae Engl., S. sect. Grandiflorae Engl. e S. sect. Tenuiflorae Engl. 17

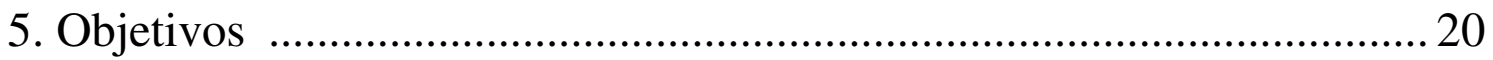

6. Estrutura geral da dissertação ............................................................... 20

Capítulo I Anatomia foliar de Simaba Aubl. (Simatoubaceae): dados estruturais como subsídio à taxonomia infragenérica .26

Capítulo II Flores de Simaba (Simaroubaceae): estrutura e novidades anatômicas em espécies de $S$. sect. Floribundae e $S$. sect. Tenuiflorae..............66 Considerações finais 94 
Resumo 
A família Simaroubaceae constitui um grupo com grande potencial de estudo. Com distribuição essencialmente tropical, é considerado um grupo relativamente pequeno dentro da Ordem Sapindales e monofilético, mas morfologicamente diversificado. Apenas Engler, no final do século XIX, estudou detalhadamente a família no Brasil como um todo, e desde então as adições ao conhecimento do grupo têm ocorrido de forma gradual e fragmentada. Esta dissertação aborda estudos estruturais de espécies do gênero Simaba, o maior da família, analisando a estrutura foliolar dos representantes de todas as suas seções, Simaba sect. Floribundae Engl., S. sect. Grandiflorae Engl. e S. sect. Tenuiflorae Engl., a fim de selecionar caracteres morfológicos e anatômicos para auxiliar os trabalhos de taxonomia deste gênero, que não recebe tratamento desde uma revisão taxonômica publicada em 1983. Além do estudo das estruturas vegetativas, neste trabalho documentamos as estruturas florais, que possuem com poucos registros de estudo na literatura do grupo, por meio de análise comparativa da morfologia e anatomia das flores de espécies pertencentes às seções $S$. sect. Floribundae e $S$. Sect. Grandiflorae, tradicionalmente distintas principalmente pelo tamanho da flor e grau de fusão do apêndice estaminal ao longo do filete, mas com grande semelhança morfológica entre si. Além de apresentar as descrições e ilustrações das características estruturais vegetativas e reprodutivas encontradas, investigamos a existência de atributos florais ainda não reportados no grupo, provendo um panorama de caracteres foliares e florais informativos para subsidiar a resolução dos problemas taxonômicos existentes no gênero e visando melhor delimitação entre as espécies que exibem grande semelhança morfológica, mesmo pertencendo ao mesmo grupo. 
Contextualização geral 


\section{A Ordem Sapindales}

Inserida no grupo das Eudicotiledôneas Rosídeas Malvídeas (APG-III, 2009), as Sapindales representam um grupo cuja monofilia é sustentada por sinapomorfias macromoleculares e pelas folhas compostas pinadas (ocasionalmente palmadas, uni ou trifolioladas) e flores com disco nectarífero muito desenvolvido (Judd. et al. 2008, Simpson 2010). Formada por nove famílias, ca de 5.200 espécies em 473 gêneros, a ordem é distribuída nas principais áreas tropicais e temperadas do mundo (Kubitzki 2011), sendo representada na região Neotropical pelas famílias Anacardiaceae, Burseraceae, Meliaceae, Rutaceae, Sapindaceae e Simaroubaceae, onde se concentra ca. $40 \%$ da diversidade total de espécies do grupo (Smith et al. 2004). Os membros desta ordem se destacam por suas características químicas e potencial econômico, além da elevada diversidade morfológica.

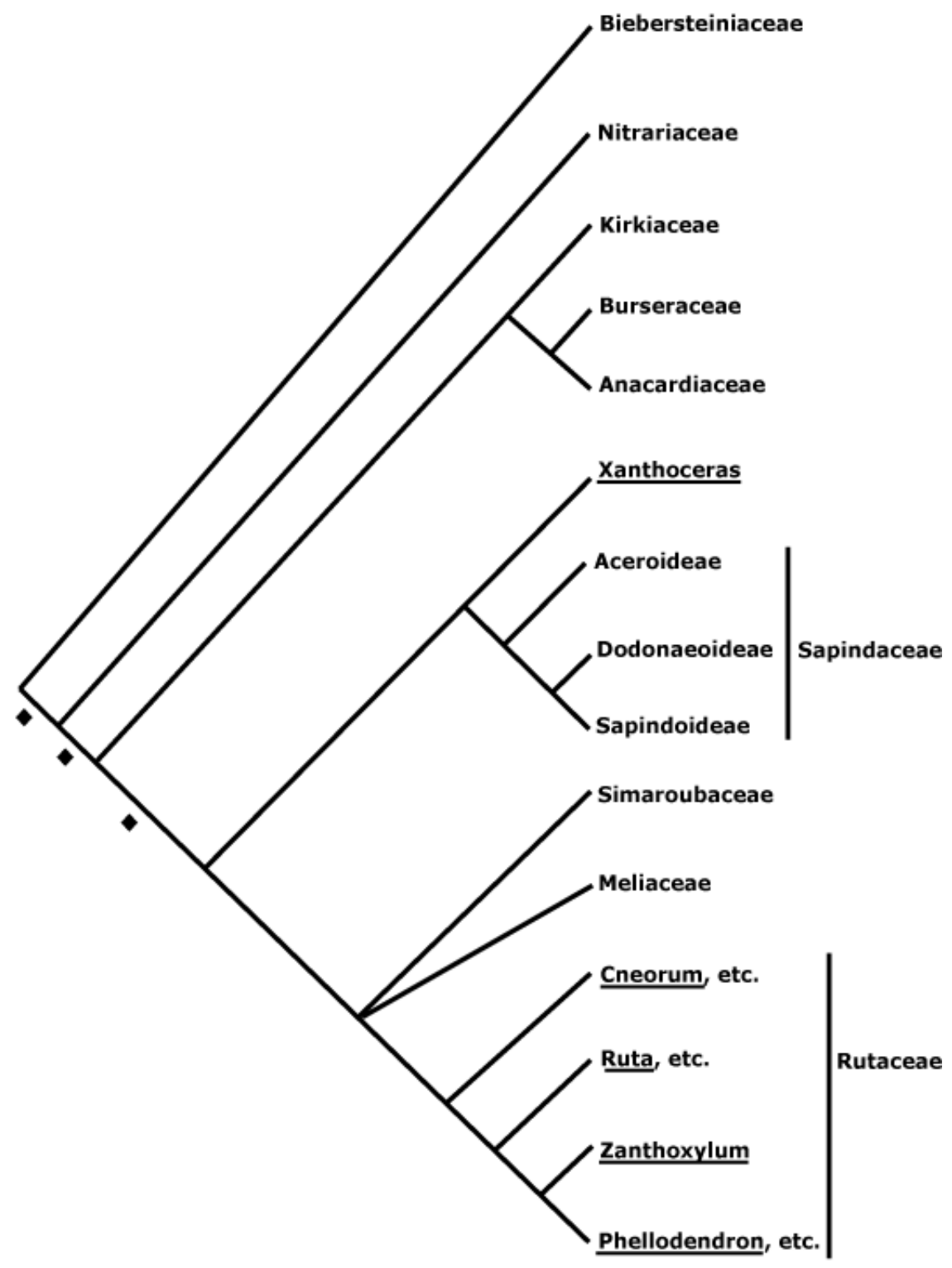

Fig.1. Relações filogenéticas dos grupos incluídos na ordem Sapindales. APGweb (Stevens 2015). 
A filogenia atualmente disponível sobre a ordem (Fig. 1) mostra Rutaceae, Meliaceae e Simaroubaceae formando um clado, embora com falta de resolução nas relações entre si. Essas três famílias compartilham a presença de limonoides e quassinoides (formas degradadas de triterpenos e nortriterpenoides), compostos incomuns nas demais angiospermas (Gadek et al. 1996, Kubitzki 2011, Kubitzki \& Gottlieb 1984). As Burseraceae e as Anacardiaceae constituem grupos-irmãos que compartilham expressivo número de caracteres morfológicos e anatômicos, principalmente florais (Gadek et al. 1996, Kubitzki 2011) (Fig. 1). Simaroubaceae, Rutaceae e Meliaceae também compartilham algumas características estruturais e a literatura tem grande disponibilidade de dados morfológicos e anatômicos sobre Rutaceae, enquanto as outras duas famílias necessitam de muito mais estudos nessa linha.

Estudos estruturais foliares e florais, foco principal do presente trabalho, são de grande importância para análises de nível específico, genérico, e em hierarquias taxonômicas superiores, pois podem contribuir de forma valiosa às suas circunscrições, além de proporcionar subsídio para entendimento da evolução dos grupos e de seus graus de relacionamento, permitindo hipóteses filogenéticas e de diversificação mais robustas.

\section{A família Simaroubaceae s.s.}

A família Simaroubaceae foi recircunscrita após análises macromoleculares (Fernando et al. 1995), constituindo agora um grupo monofilético sustentado também pela posse de quassinoides, substâncias químicas exclusivas. A família assim redefinida está constituída apenas pelos gêneros antes tratados na subfamília Simarouboideae por Engler (1931), que reconhecia outras cinco subfamílias no grupo. Picramnioideae, por exemplo, era subfamília isolada e polêmica dentro da família por não possuir quassinoides, apresentar gineceu sincárpico e fruto do tipo baga. Picramniaceae ganhou status de família, hoje posicionada como um grupoirmão de Sapindales (Fernando \& Quinn1995; APG-III 2009).

Autores como Gadek et al. 1996 e Muellner et al. 2007 prosseguiram com novas análises filogenéticas e contribuíram para a atual circunscrição de Simaroubaceae, que possui distribuição pantropical com principal centro de diversificação na América Tropical e um centro secundário na África Oriental. É um grupo relativamente pequeno dentro da ordem Sapindales, com 22 gêneros e 109 espécies (Clayton 2011). No Brasil ocorrem cerca de 6 gêneros e 27 espécies nativas distribuídas nos domínios da Amazônia, Caatinga, Cerrado e Mata Atlântica (Pirani \& Thomas 2013).

Apesar de muito bem sustentada por dados macromoleculares (DNA plastidial e nuclear) 
e dados micromoleculares (quassinoides), Simaroubaceae é morfologicamente diversificada e não apresenta uma única característica estrutural comum entre seus gêneros que não esteja presente em famílias relacionadas. As Meliaceae e Rutaceae provavelmente são os grupos mais proximamente relacionados às Simaroubaceae (Fig. 1), compartilhando além das sinapomorfias moleculares alguns caracteres morfológicos, químicos e a anatomia do lenho.

Após a monografia da família em nível global realizada por Engler (1931), o tratamento mais abrangente sobre o grupo é o de Clayton (2011), que compreende chave para os gêneros e descrições destes, além de uma hipótese filogenética das relações entre eles (Fig. 2). Essa filogenia foi baseada em três marcadores plastidiais ( $r b c L$, atpB e matK) e um marcador nuclear (phyC) (Clayton 2007).

Simaroubaceae pode então ser caracterizada pelas substâncias amargas na casca (triterpenóides e quassinoides); pelas folhas pinadas da maioria dos gêneros; pelos filetes, constantemente apendiculados na base e pelos carpelos distintos ou apenas levemente unidos (na base e/ou nos estiletes), originando frutículos livres que podem ser drupídeos ou samarídeos. Porém, nenhum destes caracteres é inteiramente constante ou exclusivo.

Apenas Engler (1874) estudou detalhadamente a família no Brasil como um todo, e as adições ao conhecimento do grupo têm ocorrido de forma gradual e fragmentada desde então. Dentre os estudos morfológicos e anatômicos de Simaroubaceae podem ser citados os de anatomia da madeira (Webber 1936; Heimsch 1942); do pericarpo (Fernando \& Quinn 1992); anatomia foliar e caulinar de Picrolemma sprucei Hook.f.(Saraiva et al. 2002); anatomia foliar de Quassia amara L. (Macedo et al. 2005) e Simarouba versicolor A.St-Hil. (Francheschinelli \& Yamamoto 1993); anatomia e fisiologia dos nectários foliares de Ailanthus altissima (Mill.) Swingle (ClairMaczulajtys \& Bory 1983; Bory \& Clair-Maczulajtys, 1990); análise morfométrica de três espécies de Simarouba Aubl. (Franceschinelli \& Yamamoto 1999a); descrição de novas espécies e subespécies de Simaba (Feuillet 1983; Thomas 1984, Franceschinelli \& Yamamoto 1999b); morfologia polínica (Erdtman, 1952, 1986; Moncada \& Machado, 1987); estudo da estrutura floral de Kirkia, revisando sua posição na ordem Sapindales (Bachelier \& Endress 2008); estudo embriológico de Leitneria corroborando sua inclusão em Simaroubaceae (Tobe 2011); estudo da estrutura, função e importância do gieneceu na sistemática de Simaroubaceae (Ramp, 1988) e a convergência do gineceu apocárpico em grandes grupos de angiospermas - Sapindales, Malvales e Gentianales (Endress et al. 1983). 


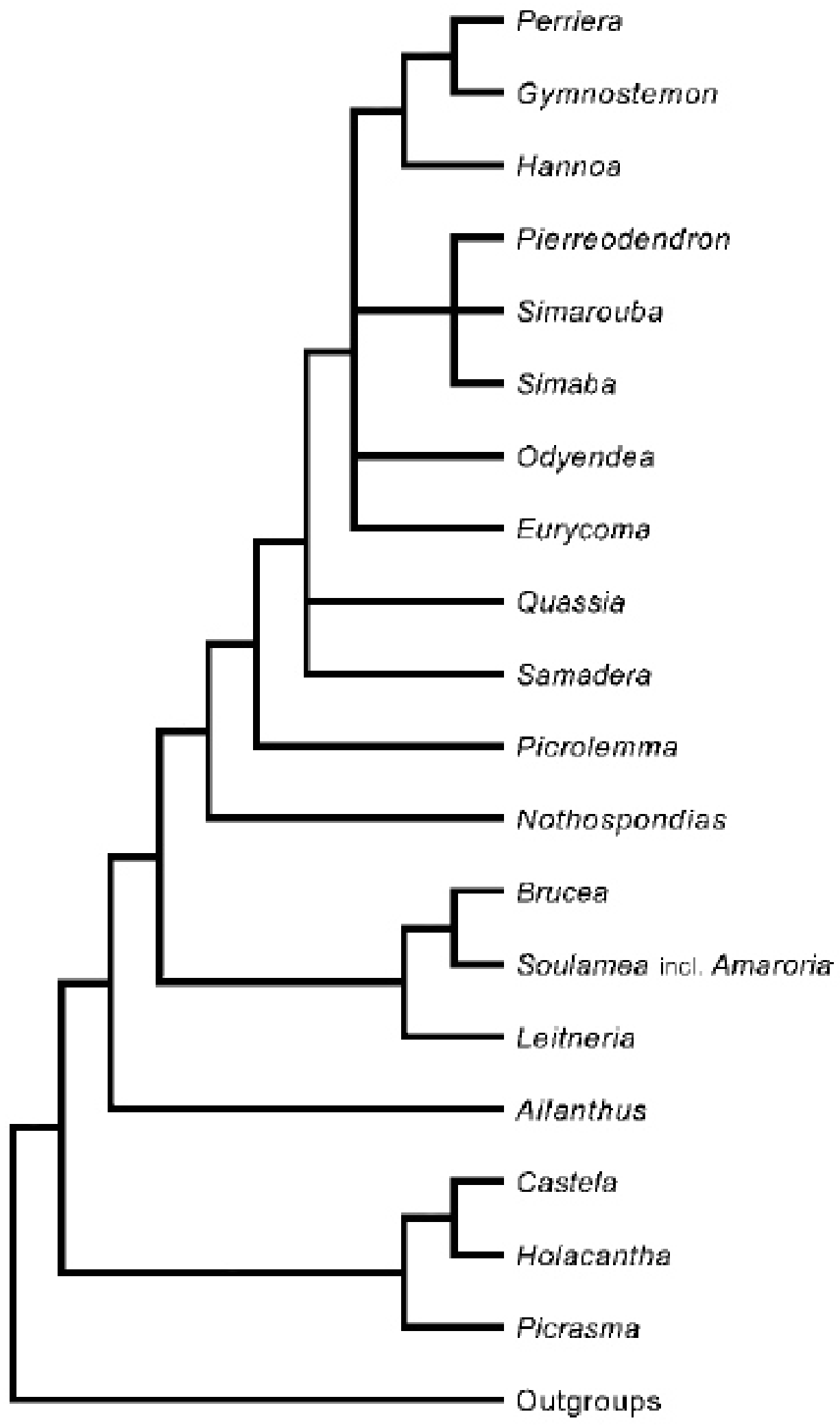

Fig. 2. Relações filogenéticas entre gêneros de Simaroubaceae. Modificado de Clayton 2007; 2011. 
$\mathrm{Na}$ família foram documentados muitos tipos de glândulas secretoras, florais e extraflorais. A presença de glândulas pedicelares, hirsutas, globulares e cupuliformes em gêneros da família foi apontada por Metcalfe \& Chalk (1950) como comum no grupo. Entre os variados tipos de nectários extraflorais estudados no grupo destacam-se os das espécies do gênero asiático Ailanthus, cuja morfologia e funcionalidade foram analisadas por Clair-Maczulajtys \& Bory (1982) e Bory \& Clair-Maczulajtys (1990). Com folhas de margem serreada, cada folíolo nessa espécie possui cerca de cinco nectários situados na terminação das nervuras secundárias, na base dos pecíolos em folhas jovens e nectários pedicelares (Bory \& Clair-Maczulajtys 1990). Glândulas localizadas no ápice do folíolo também estão presentes em grande parte das espécies do gênero neotropical Simaba, cuja ocorrência foi apontada por Engler (1931) e taxonomistas posteriores (e.g. Cronquist 1944, Cavalcante 1983, Clayton 2011) como frequentes, mas sem qualquer análise de estrutura ou composição de sua secreção na literatura do grupo que permita classificar a glândula como um nectário ou outro tipo de estrutura secretora.

Simaroubaceae possui grande importância na pesquisa etnofarmacológica, uma vez que muitas espécies são amplamente utilizadas na medicina popular, com espécies sendo empregadas no tratamento de malária, doenças estomacais e inflamatórias e diabetes, com plantas que se destacam por sua diversidade química (Alves et al. 2014). Análises fitoquímicas envolvendo representantes da família foram conduzidas por Hilditch \& Williams (1964), Simão et al. (1991), Barbosa et al. (2011) e Alves et al. 2014.

\section{O gênero Simaba Aubl.}

As plantas desse gênero são árvores, arbustos ou subarbustos, que frequentemente apresentam caule subterrâneo, desenvolvendo-se pouco abaixo da superfície do solo, podendo ser encontrados em cerrados com a parte aérea formando densas moitas (Cavalcante 1983). Suas folhas são alternas, compostas, geralmente imparipinadas, com folíolos (sub)opostos e frequentemente dotados de uma glândula no ápice (Cavalcante 1983; Clayton 2011), estrutura que é muito evidente nos folíolos jovens. As inflorescências são panículas ou tirsos terminais, curtas ou muito amplas e ramificadas. Suas flores bissexuadas constituem o principal caráter que as distinguem do gênero de Simarouba, que tem flores unissexuadas em plantas dioicas. $\mathrm{O}$ fruto é um esquizocarpo com um a cinco drupídeos (mericarpos do tipo drupa) (Engler 1931, Pirani 1987a; Clayton 2011).

Os gêneros americanos que apresentam semelhanças com Simaba são Quassia L. e Simarouba Aubl. Com o primeiro, Simaba compartilha flores bissexuadas, dotadas de ginóforo e 
estigma capitado, mas distingue-se principalmente pelas folhas com raque não alada e inflorescência ramificada (panícula ou tirso). Já Simarouba difere de ambos principalmente pelos folíolos alternos, flores unissexuadas sem ginóforo, mas com disco nectarífero anular curto e estigmas alongados bem divergentes (Engler 1931; Cronquist 1944). Noteboom (1962) propôs a união desses três gêneros sob Simaba, porém tal proposta nunca foi acatada pelos botânicos e tampouco recebeu apoio consistente na análise filognética de Clayton (2007): embora oito espécies estudadas de Simaba tenham formado um clado-irmão do clado constituído pelas quatro espécies estudadas de Simarouba, os dois terminais de Quassia emergiram em um clado bem distante deste.

Simaba é o maior gênero da família abrangendo cerca de 25 espécies, a maioria da América do Sul Tropical (Cavalcante 1983; Pirani 1987b; Thomas 1990; Clayton 2011), com uma espécie de ampla distribuição (S. cedron Planch.) alcançando o norte do México (Cronquist 1944; Thomas 1990). No Brasil, foi registrada a ocorrência de 23 espécies que se distribuem nos domínios da Amazônia, Cerrado, Mata Atlântica e Caatinga, 12 delas endêmicas do país (Pirani \& Thomas 2013).

Desde Engler $(1874,1931)$ são consideradas três seções dentro do gênero: Simaba sect. Tenuiflorae Engl., S. sect. Floribundae Engl. e S. sect. Grandiflorae Engl. Nas revisões taxonômicas feitas por Cronquist (1944) e Cavalcante (1983), esses grupos foram mantidos, mas como informais. Pelas normas do Código de Nomenclatura Botânica, se os grupos infragenéricos de Engler (1874) forem mantidos, Simaba sect. Tenuiflorae deverá ser tratada como Simaba sect. Simaba, uma vez que inclui a espécie-tipo do gênero, S. guianensis Aubl.

Franceschinelli \& Yamamoto (1999b) apresentaram uma tabela com os caracteres diagnósticos principais utilizados na distinção destas três seções e destacando a região geográfica em que as espécies de cada seção se concentram. De modo geral, Simaba sect. Tenuiflorae é caracterizada pelas flores pequenas (ca. 4-7 mm compr.) e é praticamente restrita à região norte da América do Sul, predominando nas regiões úmidas da Amazônia, com a única exceção de uma subespécie de $S$. guianensis Aubl., que também foi registrada no sul da Bahia (Thomas 1985). Já as espécies das outras duas seções são essencialmente extra-amazônicas, ocorrendo na Mata Atlântica e regiões mais secas e abertas do centro e leste do Brasil e Paraguai, com exceção de S. cedron Planch., que alcança a Amazônia Oriental e S. paraensis Ducke que é estritamente amazônica (Cronquist 1944, Cavalcante 1983). As flores nestas duas seções são geralmente bem maiores que as de $S$. sect. Tenuiflorae: medem entre 15-35 mm compr. em S. sect. Grandiflorae e ca. 5-15 mm em $S$. sect. Floribundae. Outros caracteres distintivos entre as três seções são a presença e grau de pilosidade das pétalas, o tamanho e indumento dos apêndices estaminais, e 
seu grau de união aos filetes (Engler 1874, Cronquist 1944, Cavalcante 1983, Thomas 1984). Porém, existe flagrante semelhança morfológica entre algumas espécies das duas seções extraamazônicas e por isso o limite entre elas é questionável.

O último trabalho de cunho revisivo sobre Simaba é o de Cavalcante (1983), que reconheceu 23 espécies na América do Sul e seguiu quase integralmente a sinopse de Cronquist (1944), embora enriquecendo consideravelmente a documentação dos registros em herbários e provendo descrições mais completas e várias ilustrações originais. Tal situação aponta a necessidade de atualização dos estudos no grupo. Posteriormente, foram descritos táxons novos e propostos alguns rearranjos pontuais resumidos a seguir. Simaba moretti Feuillet (1983) foi descrita da Guiana Francesa, S. cavalcantei W.Thomas (1984) do Pará e S. docensis Franceschinelli \& Yamamoto (1999b) de Minas Gerais. Em um estudo do complexo de $S$. guianensis Aubl., Thomas (1985) elevou uma subespécie à categoria de espécie [S. polyphylla (Cavalcante) Thomas], e posteriormente foi descrita mais uma subespécie neste grupo ( $S$. guianensis subsp. huberi Franceschinelli \& Thomas 2000).

\section{As seções de Simaba: S. sect. Floribundae Engl., S. sect. Grandiflorae Engl. e S. sect. Tenuiflorae Engl.}

Compilando uma lista dos táxons incluídos nas três seções de Simaba com base na mais recente revisão de Cavalcante (1983) e os trabalhos avulsos posteriores com táxons novos e sinonimizações, somam-se atualmente 24 espécies e três subespécies assim distribuídas:

Simaba sect. Floribundae inclui 14 espécies: S. cuneata A.St.-Hil. \& Tul., S. docensis Franceschinelli \& Yamamoto, S. ferruginea A.St.-Hil., S. floribunda A.St.-Hil., S. glabra Engl., S. insignis A.St.-Hil. \& Tul. S.intermedia Mansf., S. morettii Feiullet, S. praecox Hassl., S. suaveolens A.St.-Hil.; S. suffruticosa Engl. e S. subcymosa A.St.-Hil \& Tul. Apenas S. paraensis Ducke e S. cavalcantei Thomas ocorrem na Amazônia, sendo a segunda não incluída no trabalho de Cavalcante (1983).

Simaba sect. Grandiflorae inclui cinco espécies: S. cedron Planch., S. maiana Casar, S. pohliana Boas, S. salubris Engl.e S. trichilioides A.St.-Hil. A primeira é amplamente distribuída e as demais são extra-amazônicas.

Simaba sect. Tenuiflorae inclui cinco espécies e três subespécies: S. guianensis Aubl., S. monophylla (Oliv.) Cronquist, S. obovata Spruce ex Engl., S. orinocensis Kunth, S. polyphylla (Cavalcante) Thomas; S. guianensis subsp. eucaudata (Cronquist) Cavalcante, S. guianensis Aubl. subsp. guianensis e S. guianensis subsp. huberi Franceschinelli \& Thomas. Com exceção de S. obovata, todos os demais táxons desta seção são restritos à região amazônica. 
Existem muitos problemas taxonômicos nestes grupos. Por exemplo, binômios reconhecidos nas revisões de Cronquist (1944) e de Cavalcante (1983), como S. crustacea Engl. e S. multiflora A.Juss., foram reduzidos a sinônimos de S. orinocensis (Thomas 1984), enquanto uma subespécie de $S$. guianensis foi elevada a espécie, S. polyphylla (Thomas 1985). Muitos táxons de Simaba são conhecidos de uma ou poucas coletas além do material-tipo (de três espécies existe apenas o tipo) e a circunscrição de muitos deles é complicada. Autores como Pirani \& Thomas (2015) propõem S. cuneata como sinônimo de S. floribunda, mas sem suporte de dados explícitos. Embora o caráter "comprimento da porção livre do apêndice estaminal” seja tradicionalmente utilizado na taxonomia de Simaba, Cronquist (1944) já chamava atenção para a variação considerável nesse caráter, sobretudo no grupo de espécies que inclui $S$. salubris, $S$. cedron, S. maiana, S. pohliana e S. trichilioides. As diferenças tênues entre S. ferruginea, S. suaveolens e até $S$. cedron (esta pertencente a $S$. sect. Grandiflorae) também dificultam suas delimitações. Essas controvérsias têm resultado em muitas identificações errôneas nos herbários, inventários e artigos de cunho florístico (M.F. Devecchi e J.R. Pirani com. pess.).

Finalmente, ao descrever S. cavalcantei baseado em material do Pará, Thomas (1984) afirmou que a espécie congrega caracteres florais de duas seções ( $S$. sect. Floribundae e $S$. sect. Grandiflorae) e que isso corroboraria a conclusão do estudo anatômico de Boas (1913): ambas seções deveriam ser fundidas, pois suas espécies compartilham cavidades secretoras no mesofilo, que são ausentes nas espécies de $S$. sect. Tenuiflorae. Na filogenia de Simaroubaceae obtida por Clayton (2007), embora apenas oito espécies de Simaba tenham sido incluídas, nota-se que as espécies de $S$. sect. Tenuiflorae formaram um clado, enquanto as cinco espécies das outras duas seções emergiram "misturadas" (Fig. 3). Isso tudo indica a necessidade de novos estudos estruturais e taxonômicos detalhados que ampliem o grau de conhecimento do grupo a campo e em herbário, principalmente sobre os "complexos" de espécies problemáticas supramencionados destas seções, mas também visando testar os limites das próprias seções.

O presente estudo analisa a estrutura foliar e floral de espécies selecionadas das três seções de Simaba amostradas num período de dois anos. Além dos esforços de campo da autora, o apoio das expedições de coleta realizadas pelo doutorando Marcelo Fernando Devecchi, cujo projeto de tese visa à revisão, filogenia e biogeografia do gênero, possibilitou uma amplitude abrangente de táxons para este estudo, destacando-se a obtenção de amostras de três espécies amazônicas de Simaba sect. Tenuiflorae para as análises foliolares. 


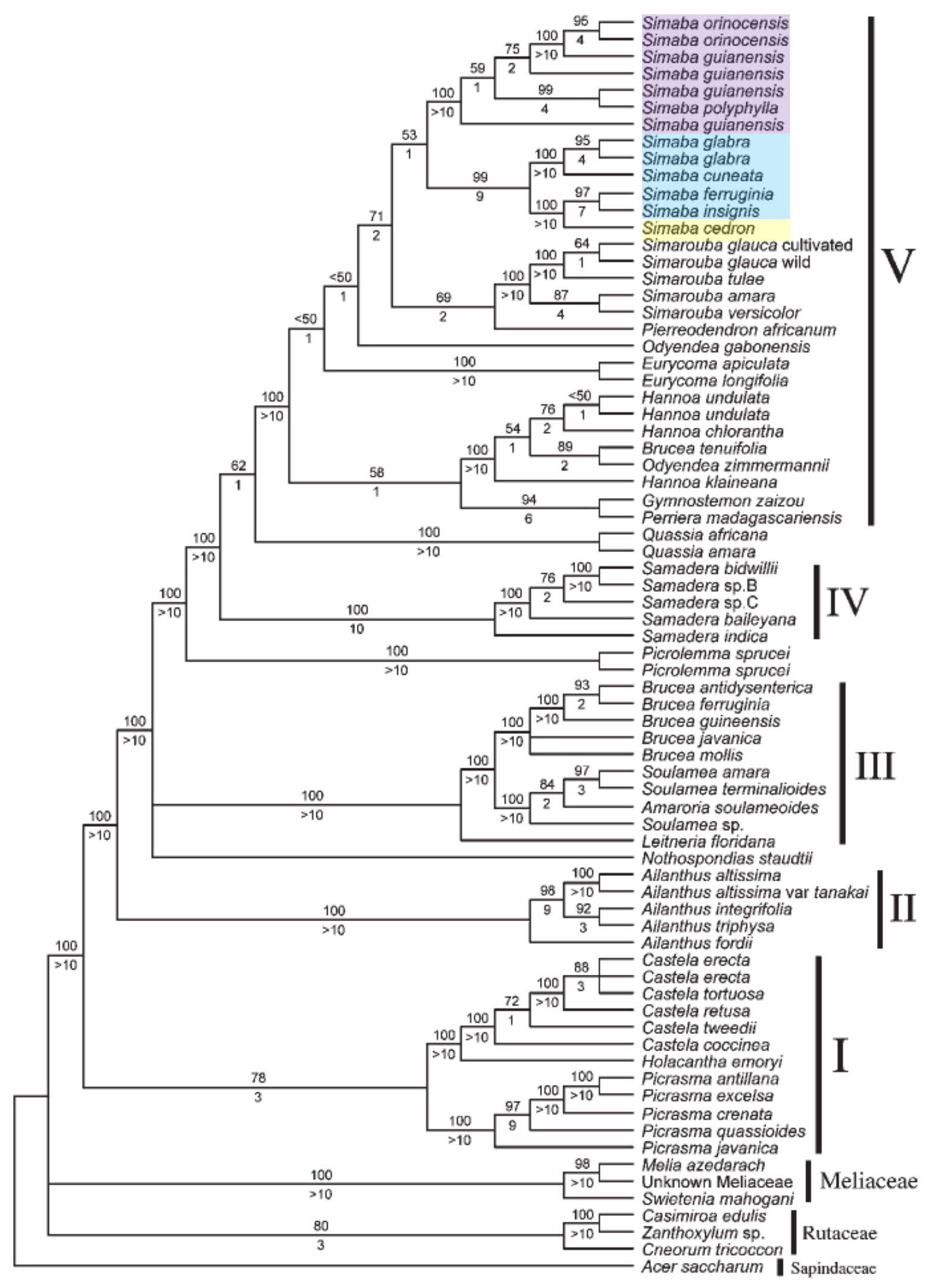

Fig. 3. Relações filogenéticas de Simaroubaceae (clados I a V) segundo Clayton (2007). No clado V, estão destacadas em roxo as espécies pertencentes à Simaba sect. Tenuiflorae; em azul, as espécies pertencentes a $S$. sect. Floribundae e em amarelo as pertencentes a $S$. sect. Grandiflorae. 


\section{Objetivos}

Os objetivos desta dissertação são:

1. Realizar um estudo estrutural detalhado das folhas e flores de espécies das três seções de Simaba, com ênfase nos táxons extra-amazônicos.

2. Completar a lacuna de conhecimento existente acerca dos caracteres anatômicos vegetativos e florais de Simaba com análise comparativa de suas semelhanças e diferenças, visando contribuir com trabalhos futuros de revisão e análise filogenética do gênero.

Para alcançar os objetivos acima mencionados, dois estudos com abordagens distintas foram realizados no decorrer do mestrado, com objetivos específicos e demais tópicos apresentados a seguir.

\section{Estrutura geral da Dissertação}

A presente dissertação é composta por dois capítulos (em formato de manuscritos) e considerações finais. Cada capítulo apresenta formatação adequada à revista que planejamos submeter cada manuscrito. Em linhas gerais, os capítulos contêm os seguintes estudos:

\section{* Capítulo 1. Anatomia foliar de Simaba Aubl. (Simaroubaceae): dados estruturais como subsídio para a taxonomia infragenérica}

Abrange o estudo da estrutura foliar de 20 táxons e 17 espécies de Simaba. Apresenta análise do padrão de venação das espécies amostradas, cortes histológicos das regiões apical, mediana da lâmina foliolar e peciólulos, além de microscopia eletrônica de varredura e de polarização para verificação do tipo de esclereídes, drusas e cristais romboidais. Neste capítulo são apresentados os caracteres anatômicos do gênero com amostragem de representantes das três seções do gênero, a fim de verificar se estes são informativos para avaliar a circunscrição destas seções e se auxiliam na resolução das questões pendentes acerca da delimitação de diversas espécies e subespécies. Almeja-se ainda que o estudo detecte caracteres anatômicos que possam ser usados na composição de uma matriz morfológica para futura análise filogenética do gênero.

Planejamos submeter este capítulo para a revista Plant Systematics and Evolution, com co-autoria do Ms. Marcelo Fernando Devecchi, Prof. Dr. Diego Demarco e Prof. Dr. José Rubens Pirani.

Adicionalmente, no decorrer da análise morfológica foi detectada a presença de glândulas côncavas na base da lâmina foliolar em S. orinocensis, ainda não descritas na literatura da 
espécie. Foi realizada análise destas estruturas em vista superficial sob microscopia eletrônica de varredura e por meio de cortes histológicos (secções transversais), a fim de verificar se suas características se diferenciam das encontradas nos nectários apicais foliolares encontrados nesta e em outras espécies do gênero. Elaboramos assim uma nota que planejamos submeter para a revista Brazilian Journal of Botany, com co-autoria do Ms. Marcelo Fernando Devecchi, Prof. Dr. Diego Demarco e Prof. Dr. José Rubens Pirani.

\section{* Capítulo 2. Flores de Simaba Aubl.: estrutura e novidades anatômicas em espécies de $S$.} sect. Floribundae Engl. e $S$. sect. Grandiflorae Engl.

Este capítulo aborda o primeiro estudo de estrutura floral com enfoque comparativo realizado com espécies dessas duas seções de Simaba. Ambas as seções são tradicionalmente distintas principalmente pelo tamanho da flor e grau de fusão do apêndice estaminal ao longo do filete. Além de apresentar as descrições e ilustrações das características florais encontradas, investigamos a existência de atributos florais ainda não reportados no grupo. Esse estudo visa prover um panorama de caracteres florais informativos para subsidiar a resolução dos problemas taxonômicos existentes no gênero e para serem usados em futura reconstrução de sua filogenia, viabilizando delinear e testar hipóteses sobre a evolução floral no grupo. Planejamos submeter este capítulo (que ainda não se encontra na forma de manuscrito) para a revista Botanical Journal of the Linnean Society, com co-autoria do Prof. Dr. Diego Demarco e Prof. Dr. José Rubens Pirani. 
Referências 
Alves, I.A.B.S., Miranda, H.M., Soares, L.A.L. \& Randau, K.P. 2014. Simaroubaceae family: botany, chemical composition and biological activities. Revista Brasileira de Farmacognosia 24: 481-501.

APG 2009. An update of the Angiosperm Phylogeny Group classification for the orders and families of flowering plants: APG III. Botanical Journal of the Linnean Society 161: 105-121.

Bachelier, J.B. \& Endress, P.K. 2008. Floral structure of Kirkia (Kirkiaceae) and its position in Sapindales. Annals of Botany 102: 539-550.

Barbosa, L.F., Braz-Filho, R., Vieira, I.J.C. 2011. Chemical constituents of plants from the genus Simaba (Simaroubaceae). Chemistry \& Biodiversity 8: 2163-2178.

Bory, G. \& Clair-Maczulajtys, D.C. 1990. Importance of foliar nectaries in the physiology of tree of heaven (Ailanthus glandulosa Desf. Simaroubaceae). Bulletin de la Société Botanique de France. Lettres Botaniques. 137(2-3):139-155.

Boas, F. 1913. Beiträge zur Anatomie und Systematik der Simarubaceen. Beiträge zur Botanische Centralblätter 29:303-356.

Cavalcante, P.B. 1983. Revisão taxonômica do gênero Simaba Aubl. (Simaroubaceae) na América do Sul. Publicações Avulsas do Museu Paraense Emílio Goeldi 37:1-85.

Clair-Maczulajty, D.C. \& Bory, G. 1983. Les nectaires extrafloraux pedicelles chez 1'Ailanthus glandulosa. Canadian Journal of Botany. 61:683-691.

Clayton, J.W., Fernando, E.S., Soltis, P.S. \& Soltis, D.E. 2007. Molecular phylogeny of the Tree-ofHeaven family (Simaroubaceae) based on chloroplast and nuclear markers. International Journal of Plant Sciences 168(9):1325-1339.

Clayton, J.W. 2011. Simaroubaceae. In: Kubitzki, K. (ed.) The families and genera of vascular plants. Vol. X. Flowering plants. Eudicots: Sapindales, Cucurbitales, Myrtaceae. Springer. Berlin. p. 408423.

Cronquist, A. 1944. Studies in the Simaroubaceae. III. The genus Simaba. Lloydia 7(1):81-92.

Endress, P.K., Jenny, M. \& Fallen, M.E. 1983. Convergent elaboration of apocarpous gynoecia in higher advanced dicotyledons (Sapindales, Malvales, Gentianales). Nordic Journal of Botany 3:293-300.

Engler, A. 1874. Simarubaceae. In: Martius, C.P.F. \& Eichler, A.G. (eds.) Vol. 12. Flora brasiliensis. Frid. Fleischer. Leipzig. p. 197-248.

Engler, A. 1931. Simaroubaceae. In: Engler, A. \& Prantl, K. (eds.) ed. 2. 19a. Die natürlichen Pflanzenfamilien. Engelmann. Leipzig. p. 359-405.

Erdtman, G. 1952. Pollen morphology and plant taxonomy. Almqvist \& Wiskell. Stockholm.

Erdtman, G. 1986. Pollen morphology and plant taxonomy: angiosperms. Bill Archive. Leiden.

Fernando, E.S. \& Quinn, C.J. 1992. Pericarp anatomy and systematic of the Simaroubaceae sensu lato. Australian Journal of Botanty 40:263-289.

Fernando, E.S., Gadek, P.A. \& Quinn, C.J. 1995. Simaroubaceae, an artificial construct: evidence from $r b c \mathrm{~L}$ sequence variation. American Journal of Botany 82:92-103.

Fernando, E.S. \& Quinn, C.J. 1995. Picramniaceae, a new family, and a recircunscription of Simaroubaceae. Taxon 44 (2):177-181.

Feuillet, C. 1983. Études sur les Simaroubaceae. II. Un Simaba nouveau de Guyane française dans la section Floribundae Engl.: S. morettii. Candollea 38(2):745-750. 
Francheschinelli, E.V. \& Yamamoto, K. 1993. Taxonomic use of leaf anatomical characters in the genus Simarouba Aubl. (Simaroubaceae). Flora. 188:117-124.

Franceschinelli, E.V.; Yamamoto, K.; Shepherd, G. J. 1999a. Distinctions among three Simarouba species. Systematic Botany 23(4):479-488.

Franceschinelli, E.V. \& Yamamoto, K. 1999b. Simaba docencis, a new Brazilian species of Simaroubaceae. Novon 9(3):345-348.

Franceschinelli, E.V. \& Thomas, W. 2000. Simaba guianensis subs. huberi, a new Venezuelan taxon of Simaroubaceae. Brittonia. 52(4):311-314.

Gadek, P.A., Fernando E.S., Quinn, C.J., Hoot, S.B., Terrazas, T., Sheahan, M C. \& Chase, M.W. 1996. Sapindales: molecular delimitation and infraordinal groups. American Journal of Botany 83(6):802-811.

Heimsch, C. 1942. Comparative anatomy of the secondary xylem in the Gruinales and Terebinthales of Wettstein with reference to taxonomic grouping. Lilloa 8:83-199.

Hilditch, T.P. \& Williams, P.N. 1964. The chemical constituent of natural facts, ed. 4. John Wiley and Sons Inc. New York.

Judd, W.S., Campbell, C.S., Kellog, E.A; Stevens, P. F., Donoghue, M. J. 2008. Plant Systematics. A phylogenetic approach. Ed. 3. Sinauer Associates. Sunderland.

Kubitzki, K. \& Gottlieb, O. 1984. Micromolecular patterns and the evolution and major classification of angiosperms. Taxon. 33:375-391.

Kubitzki, K. 2011. Introduction to Sapindales. In: Kubitzki, K. (ed.) The families and genera of vascular plants. Flowering plants. Eudicots: Sapindales, Cucurbitales, Myrtaceae. Springer Verlag. Berlin. p. $1-3$.

Macedo, C.G., Potiguara, R.C.V. \& Neto, O.R. 2005. Anatomia foliar de Quassia amara L. (Simaroubaceae), uma espécie medicinal e inseticida. Boletim do Museu Prof. Emílio Goeldi, série ciências naturais. 1(1):9-18.

Metcalfe, C.R. \& Chalk, L. 1950. Anatomy of the dicotyledons. 2 vols. Clarendon Press. Oxford.

Moncada, M. \& Machado, S. 1987. Los granos de polen de Simarubaceae. Acta Botanica Cubensis 45:1-7.

Muellner, A.N., Vassiliades, D.D. \& Renner, S.S. 2007. Placing Biebersteiniaceae, a herbaceous clade of Sapindales, in a temporal and geographic context. Plant Systematics and Evolution 266:233-252.

Nooteboon, H.P. 1962. Generic delimitation in Simaroubaceae tribus Simaroubeae and a conspectus of the genus Quassia L. Blumea 11:509-528.

Pirani, J.R. 1987a. Simaroubaceae. In Spichiger, R. (ed.) Flora del Paraguay. Conservatoire et Jardin botaniques de la Ville Genève. Missouri Botanical Garden. Saint Louis.

Pirani, J.R. 1987b. Flora da Serra do Cipó, Minas Gerais: Simaroubaceae. Boletim de Botânica da USP. 9:219-226.

Pirani, J.R. \& Tomas, W.W. 2013. Simaroubaceae In: R.C. Forzza et al. (orgs.) Lista de Espécies da Flora do Brasil. Jardim Botânico do Rio de Janeiro. Acesso em 11.02.2015.

Pirani, J.R. \& Thomas, W.W. 2015. Simaroubaceae. In: Jorgensen, P., Nee, M. \& Bech. S. (eds.) Catálogo de las plantas vasculares de Bolivia. Missouri Botanical Garden Press. Saint-Louis. p. 11991200. 
Ramp E. 1988. Struktur, Funktion und systematische Bedeutung des Gynoeciums bei den Rutaceae und Simaroubaceae. Doctoral Dissertation, University of Zurich.

Saraiva, R.C.G., Barreto, A.S., Siani, A.C., Ferreira, J.L.P., Araujo, R.B., Nunomura, S.M. \& Pohlit, A.M. 2002. Anatomia foliar e caulinar de Picrolemma sprucei Hook (Simaroubaceae). Acta Amazonica. 33(2)213-220.

Simão, S.M., Barreiros, E.L., Silva, M.F G.F. \& Gottlieb, O.R. 1991. Chemogeographical evolution of quassinoids in Simaroubaceae. Phytochemistry 30:853-865.

Simpson, M.G. 2010. Plant systematics. Ed. 2. Elsevier. Amsterdam.

Smith, N., Mori, S.A., Henderson, A., Stevenson, D.W. \& Heald, S.V. (eds.) 2004. Flowering plants of the Neotropics. Princeton University Press. Princeton.

Stevens, P.F. 2015. Angiosperm Phylogeny Website. Acesso em 20/01/2015.

Thomas, W.W. 1984. A new species of Simaba (Simaroubaceae) from Pará, Brazil, with a key to species North of the Amazon River. Brittonia 36(3):244-247.

Thomas, W.W. 1985. The Simaba guianensis complex in Northern South America. Acta Amazonica 15:71-79.

Thomas, W.W. 1990. The American genera of Simaroubaceae and their distribution. Acta Botanica Brasilica 4(1):11-18.

Tobe, H. 2011. Embryological evidence supports the transfer of Leitneria floridana to the family Simaroubaceae. Annals of the Missouri Botanical Garden 98(2): 277-293.

Webber, I.E. 1936. Systematic anatomy of the woods of Simaroubaceae. American Journal of Botany 23:577-587. 
Capítulo 1

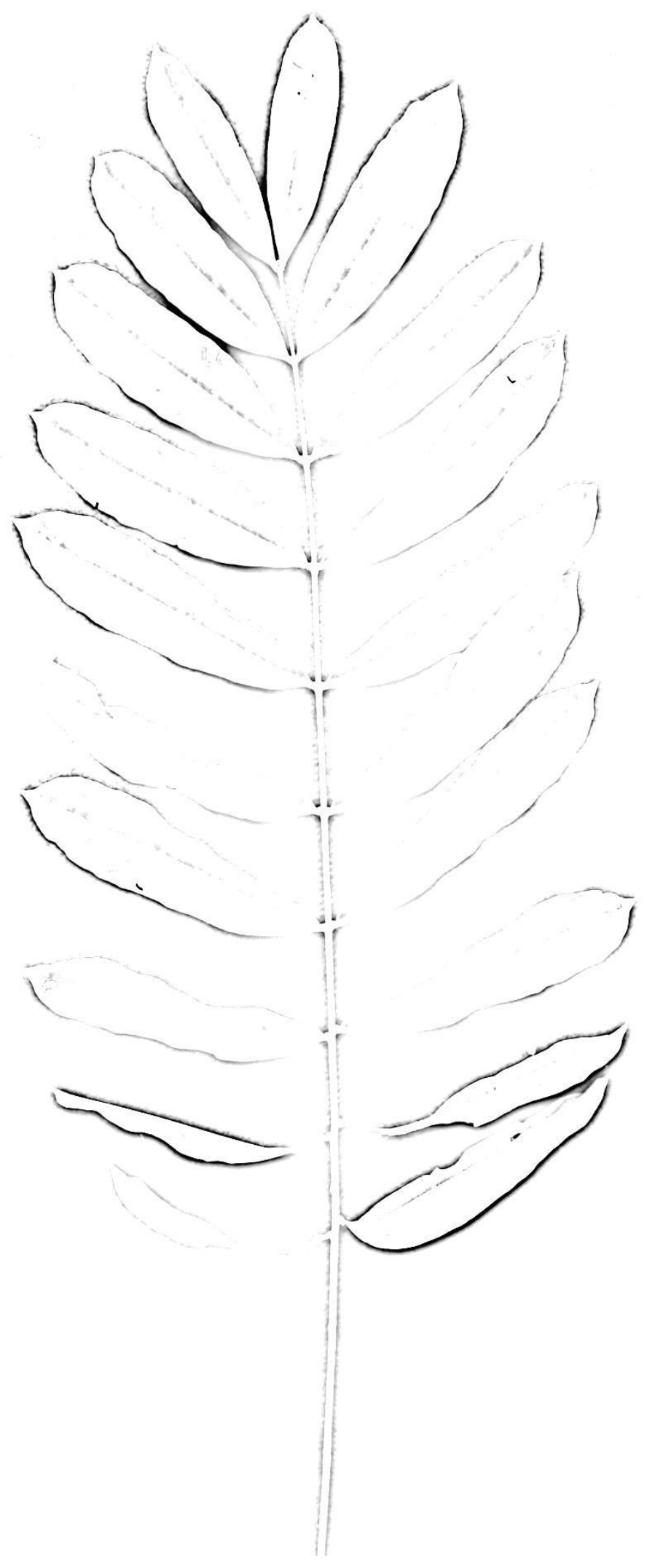




\title{
Anatomia foliar de Simaba Aubl. (Simaroubaceae): dados estruturais como subsídio para a taxonomia infragenérica.
}

\author{
Gisele Alves ${ }^{1}$, Marcelo Fernando Devecchi ${ }^{1}$, Diego Demarco ${ }^{2} \&$ José Rubens Pirani $^{1}$. \\ ${ }^{1}$ Laboratório de Sistemática Vegetal, ${ }^{2}$ Laboratório de Anatomia Vegetal, Departamento de \\ Botânica, Instituto de Biociências, Universidade de São Paulo. \\ Para correspondência: giselealves@usp.br
}

\section{Resumo}

A família Simaroubaceae é um grupo monofilético essencialmente tropical, inserido na Ordem Sapindales. Embora relativamente pequena, é morfologicamente muito diversificada e por isso exibe grande potencial de pesquisa estrutural. Estudos anatômicos foliares são escassos neste grupo, que não apresenta uma única característica estrutural documentada que seja exclusiva de quaisquer de seus gêneros ou que não esteja presente em famílias relacionadas. Neste trabalho levantamos caracteres estruturais dos folíolos de Simaba, maior gênero da família com cerca de 25 espécies que se distribuem pela América do Sul tropical e que não recebem tratamento taxonômico desde 1983 e estudo anatômico desde 1913. Uma vez que as adições ao conhecimento estrutural deste grupo vêm ocorrendo de forma fragmentada, intencionamos com este estudo levantar dados morfológicos e anatômicos dos folíolos de Simaba, a fim de aprimorar o conhecimento da estrutura foliar do grupo e verificar se esses caracteres são informativos para subsidiar a reavaliação da circunscrição de espécies e subespécies de Simaba e suas três seções. A análise morfológica e anatômica foliar de 20 táxons e 17 espécies de Simaba revelou como principais características gerais as folhas hipostomáticas, presença de ductos secretores, padrão de venação secundária broquidódroma e terciária intercostal percurrente e diferentes padrões de vascularização nos peciólulos e região mediana da nervura central. Diversos outros caracteres ainda não documentados para o gênero foram identificados e podem ser promissores para a delimitação de espécies e auxiliar a reavaliação das seções de Simaba.

Palavras-Chave: Simaroubaceae, Morfoanatomia foliolar, Estudo comparativo. 


\title{
Foliar anatomy in Simaba Aubl. (Simaroubaceae): structural insights towards an improvement of the infrageneric taxonomy
}

\begin{abstract}
The Simaroubaceae family is a monophyletic group with tropical distribution and inserted in the Order Sapindales. Although relatively small, Simaroubaceae is morphologically diverse and exhibits a wide potential for structural studies. Foliar anatomy analyses are scarce in this group, which does not present one single recognized structural characteristic exclusive of any of its genera or not found in the related families. This study shows the leaflets structural characters of Simaba, which is the largest genus in the family, with about 25 species distributed through tropical South America. The genus has not been revised taxonomically since 1983, and its last anatomical study dates back to 1913 . We intend in the present study to document morphological and anatomical data of Simaba leaflets, with the aim to enhance the knowledge of Simaroubaceae leaf structure and verify whether these characters are informative to support the circumscription of species and subspecies of Simaba, as well as its three sections. The analysis of the petiole, leaflet blade and leaflet apex of 20 taxa and 17 Simaba species revealed as main characteristics: hypostomatous leaves, presence of secretory ducts, leaf venation pinnate with a brochidodromous pattern in which second-order veins are jointed, tertiary percurrent intercostal, in which third-order veins are jointed, as well as different vasculature patterns in the petiolules and in the middle region of theblade midrib. Several other characters not previously documented for the genus were identified and may help the delimitation of species and the reevaluation of the three sections.
\end{abstract}

Key words: Simaroubaceae, Leaflet morphoanatomy, Comparative study. 


\section{Introdução}

As folhas das plantas vasculares exibem ampla diversidade de desenvolvimento, podendo apresentar grandes variações em relação a tamanho, forma e complexidade, destacando-se a ocorrência de estruturas inteiras ou subdivididas (Sinha 1999). Estas variações podem existir entre indivíduos de uma mesma população ou ainda em uma mesma planta (Smith \& Hake 1992), o que torna seu estudo objeto de grande valor taxonômico. Ademais, a análise da morfologia foliar é de grande importância para a caracterização e identificação de táxons quando as variações das estruturas florais não são suficientemente informativas (Stace 1989).

Os atributos morfológicos foliares comumente empregados em descrições taxonômicas referem-se à complexidade baseada no número de unidades laminares (i.e. lâmina simples ou composta), indumento, venação e modificações como bainha, estípulas, pecíolo ou raque aladas, entre outros (Radford et al., 1974; Bell \& Bryan, 2008). O conhecimento sobre aspectos ontogenéticos das folhas também é fundamental para detecção das homologias estruturais entre táxons de diversas hierarquias, permitindo a construção de matrizes robustas para reconstrução de filogenias e estabelecimento de hipóteses consistentes sobre evolução dessas estruturas ao longo da história dos grupos em foco (Wheeler 2012).

As folhas compostas, por exemplo, surgiram independentemente múltiplas vezes ao longo da evolução das plantas vasculares, e as evidências de mecanismos de desenvolvimento divergentes têm estimulado controvérsia sobre homologias entre os grupos (e.g. Bharathan et al. 2002; Friedman et al, 2004). Efroni et al. (2010) enfatizam que os diferentes mecanismos moleculares de ontogênese de folhas compostas já documentados em vários grupos de angiospermas podem ter maior ou menor grau de homologia. Cruz et al. (no prelo) apresentaram estudo do desenvolvimento foliar em Metrodorea (Rutaceae) com análise ontogenética de folhas simples e pinadas, uni e trifolioladas e apontam que todos os membros de Sapindales provavelmente com partilham um ancestral com folhas compostas e as espécies com apenas uma lâmina são prováveis resultados de uma redução evolutiva.

Existem poucos estudos tratando das folhas de representantes da família Simaroubaceae, pertencente à ordem Sapindales, um grupo de Rosídeas lenhosas fortemente sustentado por evidências macromoleculares e cuja principal sinapomorfia seria a posse de folhas compostaspinadas (Gadek et al. 1996). No entanto, os representantes dessa família exibem ampla diversidade de estrutura foliar, possuindo folhas compostas-pinadas, trifolioladas, unifolioladas e simples, inclusive com "pseudoestípulas" presentes em Ailanthus, Picrasma e Soulamea (Engler 1931; Weberling \& Leenhouts 1966; Clayton 2011). Em espécies destes três gêneros, os folíolos são heteromórficos com o par proximal reduzido a vestígios que lembram estípulas, devido não 29 
apenas ao seu pequeno tamanho, mas por estarem posicionados junto à base do pecíolo e muitas vezes envolvendo a base foliar e o eixo caulinar de maneira semelhante à das estípulas. Uma maior investigação sobre como se deu a evolução de folhas simples e pinadas em Simaba deve ser realizada uma vez que esta variação é constante nos membros de Sapindales.

Os escassos dados anatômicos foliares sobre representantes de Simaroubaceae constam dos trabalhos de Boas (1913), Engler (1931), Metcalfe \& Chalk (1950) e Cronquist (1981). Estes descrevem as folhas na família como usualmente dorsiventrais, raramente isobilaterais com epiderme frequentemente mucilaginosa e ocasionalmente papilosa, estômatos usualmente confinados à face abaxial com idioblastos sendo comuns no mesofilo foliar. O pecíolo comumente exibe padrão vascular cilíndrico que, em alguns gêneros, circunda feixes vasculares acessórios cuja orientação e distribuição vem sendo utilizadas para identificação de espécies. Ductos secretores ocorrem em certos gêneros principalmente na região periférica da medula, de onde se estendem ao longo do pecíolo para a nervura mediana. Células secretoras contendo óleo, resina ou menos comumente mucilagem são encontradas em meio ao parênquima (Metcalfe \& Chalk 1950).

Simaba é o maior gênero da família, abrangendo ca. 25 espécies exclusivamente neotropicais, distribuídas em três secções: S. sect. Floribundae Engl., S. sect. Grandiflorae Engl. e S. sect. Tenuiflorae Engl. (Cronquist 1944; Cavalcante 1983). No Brasil são registradas 23 espécies (Pirani \& Thomas 2015). Trata-se de plantas com hábito arbóreo, arbustivo ou subarbustivo, que frequentemente apresentam sistema subterrâneo muito desenvolvido nas espécies encontradas em cerrados, cuja parte aérea pode formar densas moitas (Cavalcante, 1983). Suas folhas são alternas, unifolioladas ou mais frequentemente compostas imparipinadas, com folíolos (sub)opostos e frequentemente dotados de uma glândula no ápice (Cavalcante 1983; Clayton 2011), estrutura que costuma ser muito evidente, sobretudo nos folíolos jovens e cuja natureza precisa de melhor investigação.

Os estudos estruturais existentes sobre Simaba restringem-se essencialmente aos caracteres morfológicos constantes nas obras taxonômicas de Engler, (1931) Cronquist (1944) e Cavalcante (1983) e estudos de anatomia foliar feitos por Jadin (1901) e Boas (1913). Mesmo com poucos dados disponíveis, esses autores exararam conclusões ou considerações gerais, algumas ainda hoje controvertidas. Boas (1913) sugeriu que a ausência de ducto secretor no folíolo de espécies de Simaba sect. Aruba (atual seção Tenuiflorae) sustentaria a necessidade de fusão de Simaba sect. Floribundae e S. sect. Grandiflorae, enquanto autores como Metcalfe \& Chalk (1950) e Jadin (1901) afirmaram não haver um único caráter anatômico suficiente para distinguir gêneros ou espécies na família. 
A escassez de dados sobre os caracteres vegetativos de Simaba nos levou a propor o estudo estrutural de alguns atributos foliares e a análise anatômica dos folíolos de espécies do gênero, a fim de aprimorar o conhecimento da morfologia foliar do grupo e verificar o quanto estes caracteres podem ser informativos para auxiliar estudos filogenéticos e de revisão taxonômica, incluindo reavaliação da circunscrição de suas três seções.

\section{Material e métodos}

Das 25 espécies atualmente reconhecidas em Simaba, materiais de 17 espécies foram analisados anatomicamente, alguns também foram examinados em microscopia eletrônica de varredura, diafanização para análise da venação e dissociação epidérmica. Foram analisados ainda folíolos de uma espécie do gênero relacionado Simarouba para fins comparativos. A lista de espécies bem como seus respectivos espécimes-testemunho (vouchers) encontra-se na tabela 1.

Para obtenção do material utilizado neste estudo foram realizadas expedições de coleta por estados das regiões sudeste, norte e central do Brasil, empregando-se métodos usuais de coleta e herborização de material botânico (Fidaldo \& Bononi, 1989; Mori et al. 1989; Simpson, 2010). Os espécimes-testemunho (vouchers) estão depositados no herbário SPF do Departamento de Botânica do IBUSP. Para complementação de algumas análises utilizamos partes de folhas de espécimes disponíveis no acervo do herbário SPF. Muitas observações de aspectos gerais das folhas foram feitas sob estereomicroscópio Leica M125 no Laboratório de Sistemática do Departamento de Botânica do IBUSP.

Todas as preparações para os estudos anatômicos descritos a seguir foram executadas no Laboratório de Anatomia do Departamento de Botânica do IBUSP.

Para análise anatômica dos folíolos, o material foi previamente fixado em FAA (Johansen 1940) por $24 \mathrm{~h}$ sob vácuo, sendo posteriormente estocado em etanol $70 \%$. O ápice foliolar e segmentos das regiões medianas da nervura central, margem foliolar e peciólulo foram isolados, desidratados em série butílica ascendente (álcool butílico terciário; Johansen 1940), incluídos em Paraplast e seccionados transversalmente em micrótomo rotativo LEICA RM2145 com $25 \mu \mathrm{m}$ de espessura. As lâminas foram coradas com azul de astra e safranina (Gerlach 1984) e montadas com resina Permount. As análises anatômicas dos folíolos e peciólulos foram realizadas em microscópio óptico LEICA DM400B com câmera acoplada.

O material foliar estocado em etanol $70 \%$ foi seccionado manualmente nas regiões de interesse do estudo (ápice, nervura, margem e peciólulo dos folíolos) e os segmentos transversais 
foram clarificados em água sanitária a 50\%, corados com safranina 1\% em etanol 50\% e azul de astra $1 \%$ em meio aquoso (Gerlach 1984) e montados em lâminas semi-permanentes com glicerina a 50\% (Purvis et al. 1964).

A análise da ornamentação cuticular e detalhes dos tricomas, estômatos e glândulas apicais foliolares foi realizada sob microscopia eletrônica de varredura (MEV). Segmentos medianos da lâmina foliolar foram secos pelo método de ponto crítico e metalizados com ouro, conforme descrito em Silveira (1989). As imagens foram obtidas em microscópio ZEISS DSM 970.

A análise do tipo de estômato e tipo de paredes epidérmicas foi feita utilizando folíolos herborizados submetidos à técnica de dissociação da epiderme com peróxido de hidrogênio e ácido acético (Franklin 1945). A descrição está baseada nos critérios de Radford et al. (1974).

Para a descrição e classificação dos padrões de venação os folíolos foram diafanizados, adaptando-se o método proposto por Strittmater (1973). O material foi submetido inicialmente a hidróxido de sódio $5 \%$ por duas horas. Em seguida, as folhas foram lavadas com hipoclorito de sódio 5 ou $10 \%$ até a clarificação. A clarificação total foi obtida submetendo-se posteriormente o material ao cloral hidratado a $5 \%$. Os folíolos clarificados foram desidratados e corados com safranina $1 \%$ em etanol $100 \%$ e acetato de butila (1:1). As folhas foram distendidas em placas de vidro e montadas com Bálsamo-do-Canadá. Os padrões de vascularização foram determinados segundo Ellis et al. (2009). A obtenção de imagens dos padrões foi obtida com câmera fotográfica com auxílio de caixa de luz.

Foram esquematizados os padrões vasculares encontrados nos peciólulos das espécies, bem como os da nervura central. As imagens foram obtidas em microscópio óptico LEICA DM400B com câmera acoplada e os padrões de distribuição dos feixes vasculares foram esquematizados em papel vegetal. As imagens foram vetorizadas utilizando o programa Ilustrator.

A presença de cristais romboidais e drusas na nervura central e peciólulos de algumas espécies foi confirmada com a realização de microscopia eletrônica de polarização e as imagens registradas em microscópio LEICA DMLB com câmera acoplada.

Adicionalmente, foram analisados cortes histológicos das glândulas presentes na base dos folíolos de $S$. orinocensis obtidos a partir dos materiais incluídos em historresina LEICA, seccionados em micrótomo rotativo LEICA RM2145 e corados com azul de toluidina (O’Brien et al. 1964). Teste com glicofita para verificar a presença de glicose no exsudato das glândulas do ápice e lâminas foliolares também foi realizado. 
Tabela 1. Lista de vouchers dos materiais de Simaba e Simarouba utilizados nas análises estruturais.

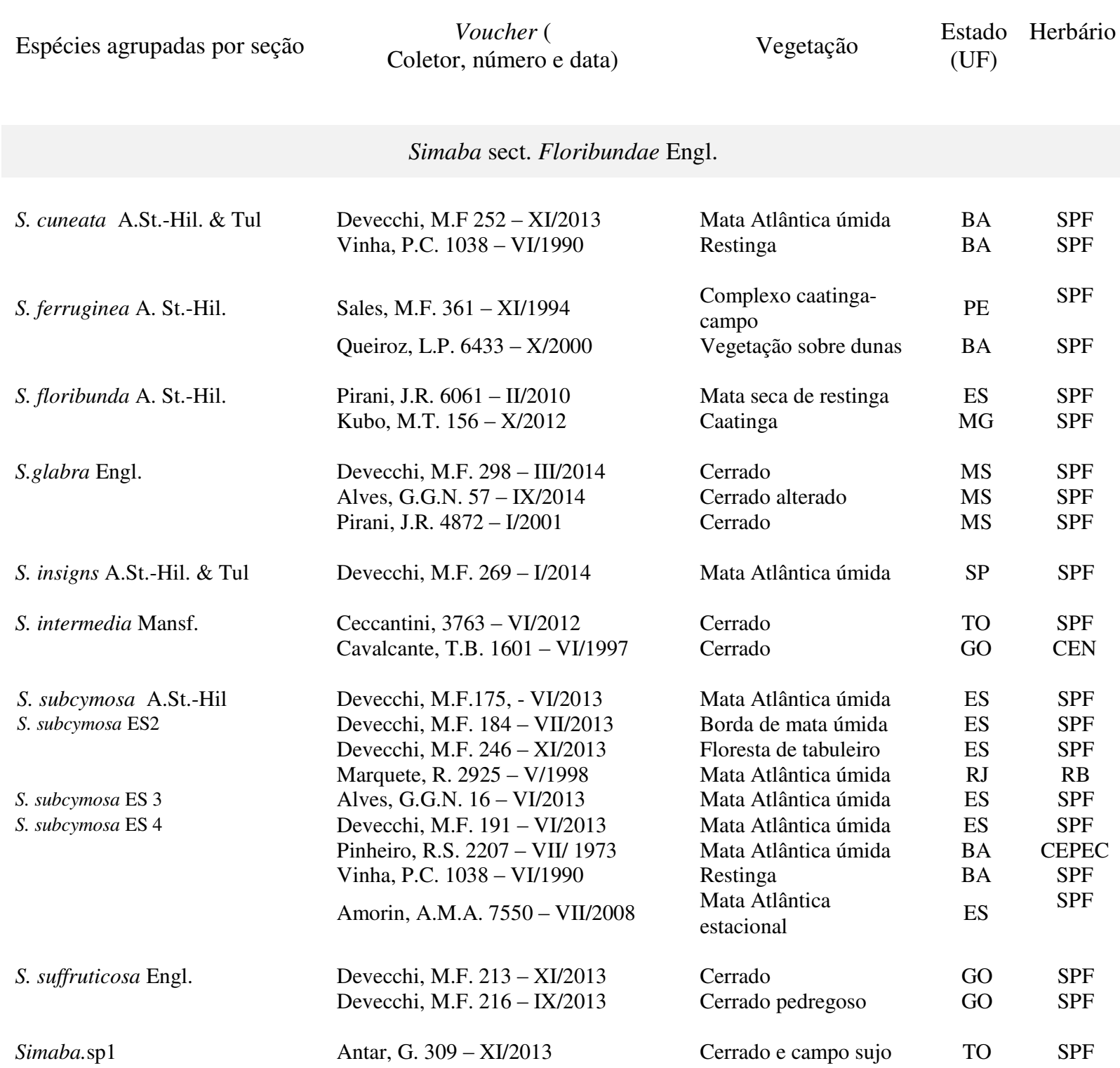

Simaba sect. Grandiflorae Engl.

S. cedron Planch.

S. pohliana Boas

S. salubris Engl.

S. trichilioides A.St.-Hil.
Devecchi, M.F. 173 - VI/2013

Devecchi, M.F. 194 - VII/2013

Devecchi, M.F. 238 - IX/2013

Devecchi, M.F. $267-$ XII/2013

Devecchi, M.F. 261 - XII/ 2013

Thomas, W.W. 6037 - II/1988

Pereira, E. 1818 - II/1995

Paula-Souza, J. - X/2007

Devecchi, M.F. 295 - III/2014

Devecchi, M.F 296 - III/2014

Devecchi, M.F. 226 - IX/2013

Devecchi, M.F. 235 - IX/2013

Ribeiro, W.R. s/n - I/1997

$\begin{array}{lcc}\text { Floresta de tabuleiro } & \text { ES } & \text { SPF } \\ \text { Mata Atlântica úmida } & \text { ES } & \text { SPF } \\ \begin{array}{l}\text { Cerrado } \\ \text { Mata de terra firme }\end{array} & \text { GO } & \text { SPF } \\ \begin{array}{l}\text { Mata secundária } \\ \text { Mata Atlântica úmida }\end{array} & \text { SPF } & \text { SPF } \\ \text { Cerrado } & \text { BA } & \text { SPF } \\ \text { Cerradão } & \text { TO } & \text { SPF } \\ \text { Cerrado } & \text { SPF } \\ \text { Cerrado e pastagem } & \text { MS } & \text { SPF } \\ \begin{array}{l}\text { Cerrado } \\ \text { Cerrado pedregoso } \\ \text { Mata de tabuleiro }\end{array} & \text { GP } & \text { SPF } \\ \end{array}$


Simaba sect. Tenuiflorae Engl.

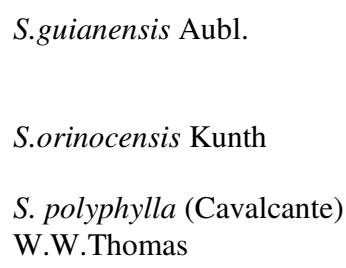

Simarouba Aubl

$\begin{array}{lcc}\begin{array}{lcc}\text { Mata Atlântica úmida } \\ \text { Mata de terra firme }\end{array} & \text { ES } & \text { SPF } \\ \text { Em cultivo } & \text { PA } & \text { SPF } \\ & & \text { SPF } \\ \text { Mata de terra firme } & \text { AM } & \end{array}$

Mussununga (restinga)
ES

SPF

\section{Resultados e Discussão}

Morfologia geral

As espécies estudadas apresentam hábito arbóreo ou arbustivo. Simaba cedron, $S$. guianensis, S. insigns, S. orinocensis e S. polyphylla, S. salubris e S. subcymosa constituem desde arvoretas delgadas até árvores que podem alcançar grande porte (Fig. 1a). As demais espécies são arbustos em que a parte aérea pode ser pouco a muito desenvolvida ( $S$. trichilioides), com casos de arubustos com sistema subterrâneo espessado e alongado pouco abaixo da superfície do solo, rebrotando e/ou florescendo após a seca ou queimadas como em Simaba sp1, Simaba sp2, S. glabra e S. suffruticosa (Fig. 1b). O hábito geoxílico é amplamente conhecido em espécies de cerrado de várias famílias de angiospermas, como Anacardium, Andira, Craniolaria, Erythroxylum, Gomphrena e Mimosa, e tem sido considerado uma adaptação a ambientes de solos pobres em nutrientes, clima seco e com presença de fogo (e.g. Rachid 1947, Rizzini \& Heringer 1961, Simon \& Pennington 2012).

Simaba é caracterizado por possuir folhas alternas, compostas-imparipinadas (Fig.1c), podendo raramente ocorrer folhas unifolioladas como nas espécies amazônicas S. monophylla e S.obovata (Fig. 1d), que possuem duas articulações no pecíolo. Os folíolos são opostos a subopostos, com margem inteira, lâminas cartáceas a coriáceas, glabras ou indumentadas, subsésseis ou com peciólulos curtos que podem ser ligeiramente intumescidos ou espessados (Cronquist 1944; Cavalcante 1983).

Os folíolos de Simaba apresentam uma glândula no ápice, estrutura que é muito evidente nos folíolos jovens e em algumas espécies, menos conspícuos (Fig.1c, em detalhe) O presente 
trabalho também identificou pela primeira vez a presença de um a dois pares de glândulas na base foliolar de S.orinocensis, entre o peciólulo e a lâmina, estrutura não documentada na descrição original (Kunth 1823) nem nos demais trabalhos tratando da espécie (e.g. Cavalcante 1983). Neste trabalho, foram realizados cortes anatômicos para investigação da estrutura e composição da glândula apical destes folíolos, bem como das glândulas presentes na base dos da espécie S. orinocensis, cujos dados serão mostrados a seguir.

As flores de Simaba são geralmente pentâmeras, dialipétalas, com estames dotados de apêndices (Fig.1e, f, g, i), originando frutos esquizocárpicos com um a cinco carpídios do tipo drupa (Fig.1h, j, k, l).

Fig. 1 Morfologia geral de Simaba. A. Porte arbóreo de S. subcymosa; B Porte arbustivo, em S. suffruticosa com caule subterrâneo exposto; C. Folhas compostas-imparipinadas em S. ferruginea; em detalhe: glândula apical em folíolo de S.cedron; D. Folhas unifolioladas em S. obovata; E. Flor de S. subcymosa (S. sect. Floribundae); F. Flor de S. cedron (S. sect. Grandiflorae); G. Flor de S. orinocensis (S. sect. Tenuiflorae); H. Frutos de S. ferruginea; I. Inflorescência de S.obovata; J. Frutos de S. insigns; K. Frutos de S. obovata;L. Frutículo imaturo de S. glabra. Fotos de Devecchi, M.F. 

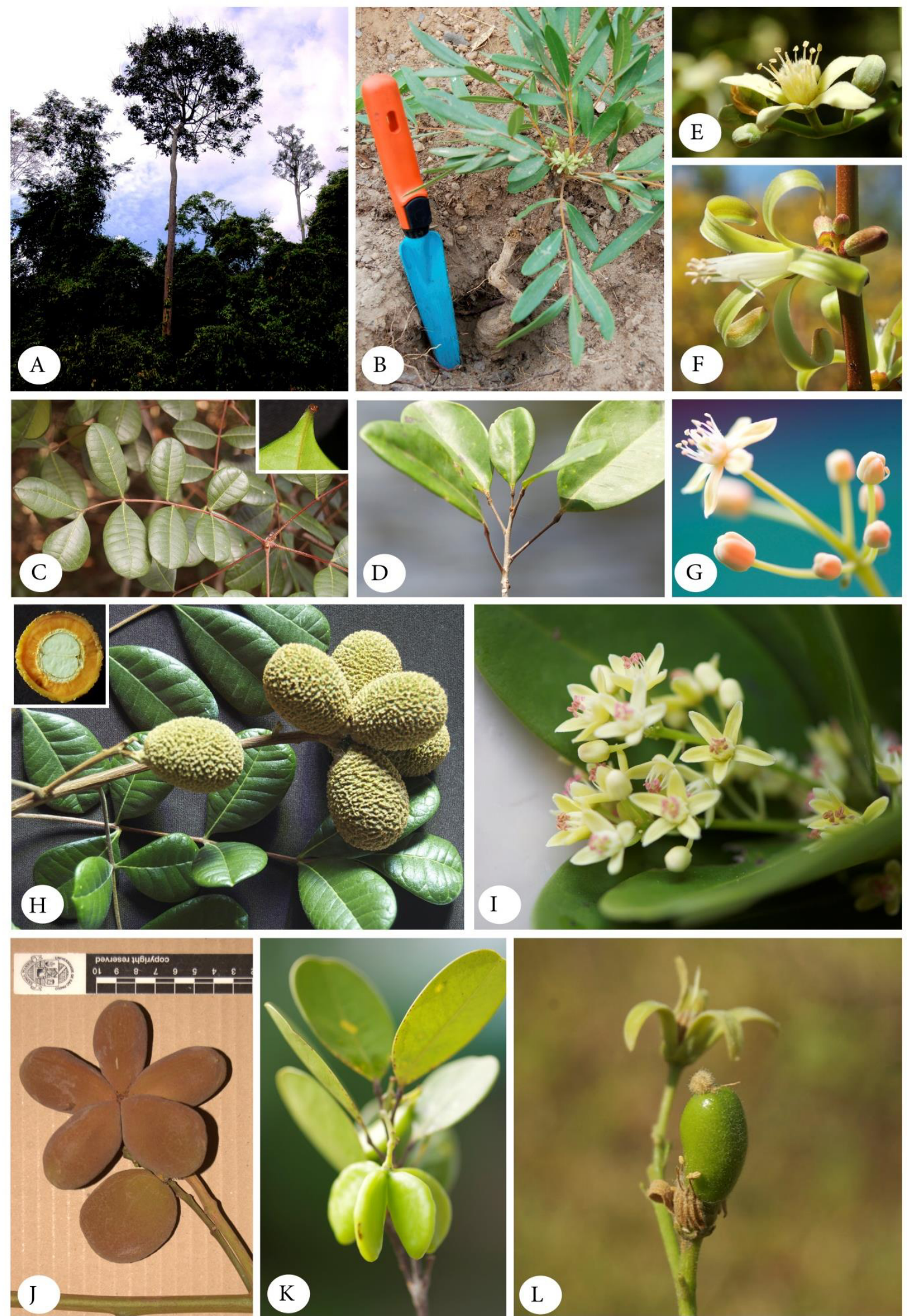

L

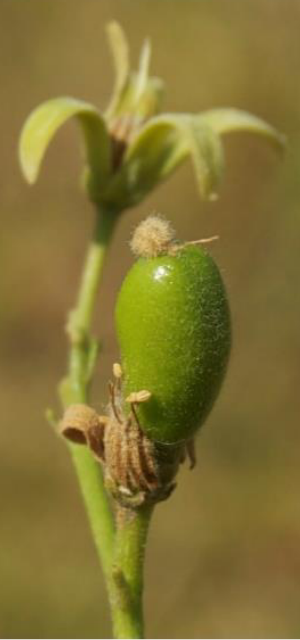


Peciólulo

Os representantes da Ordem Sapindales possuem como características dos pecíolos e peciólulos a presença de cordões medulares, feixes vasculares corticais ou adaxiais e presença de ductos secretores esquizógenos ou esquizolisígenos (Anacardiaceae) contendo resina ou bálsamo (Lacchia \& Carmello-Gerreiro 2009; Álvarez et al. 2008). Em Simaba, a organização do tecido vascular, bem como o número de feixes ou ductos varia entre as espécies (Figuras 2, 3 e 4) e os feixes vasculares principais possuem crescimento secundário, bem como a epiderme de algumas espécies (Fig. 5a; b). Os caracteres de cada espécie encontram-se na tabela 2.

O significado de todos os padrões de vascularização nos peciólulos ainda não é totalmente compreendido. Nas folhas, o sistema vascular forma diversos padrões que estão relacionados ao direcionamento polarizado da auxina. Esse hormônio pode determinar a diferenciação dos feixes vasculares, indicando que as vias envolvidas na formação destes padrões podem ser descobertas com o isolamento dos genes relacionados ao seu fluxo (Ye, 2002). A vascularização encontrada nos peciólulos de Simaba também possui muitos cordões de floema acessórios e/ou acompanhados por feixes vasculares acessórios, podendo ser correlacionados com o volume de transporte de açúcares pelos tubos crivados (Evert, 2006). Estes padrões podem assegurar a distribuição apropriada de açúcares a partir de diferentes partes da lâmina, em especial de folhas grandes, como é o caso de $S$. cedron e $S$. insignis, que chegam a 2 metros de comprimento, com folíolos bem maiores que os das demais espécies. Metcalfe \& Chalk (1950) apontaram a ocorrência de feixes vasculares acessórios para Simaroubaceae e famílias relacionadas, como Burseraceae e Meliaceae.

Boas (1913) afirmou que para os representantes de Simaba a ausência deste tipo de ducto nas espécies de $S$. sect. Tenuiflorae corroboraria a distinção desta seção, mas enfraqueceria a distinção entre $S$. sect. Floribundae e S. sect. Grandiflorae. Embora não apareçam nos cortes de todas as espécies analisadas (Fig. 5c, d) a presença ou ausência de ductos secretores (seja no parênquima ou no protoxilema e/ou xilema) não pode ser utilizada para delimitar seções, uma vez que eles não são contínuos por toda a folha e podem não ter sido cortados na região analisada.

Cristais romboidais foram registrados em algumas espécies e, quando presentes, são mais abundantes no floema e parênquima adjacente, podendo ocorrer também a presença eventual de drusas (Fig. 5e, f). Um anel de esclerênquima envolve o sistema vascular do peciólulo de todas as espécies analisadas (Fig. 5b). Metcalfe \& Chalk (1950) apontam o uso da posição dos feixes vasculares do pecíolo para diferenciação de espécies em Simaroubaceae. Em Simaba, estes padrões variam em nível infragenérico, mas não são congruentes com a delimitação das seções. 
Fig. 2 Esquema dos padrões de vascularização dos peciólulos nas espécies estudadas.
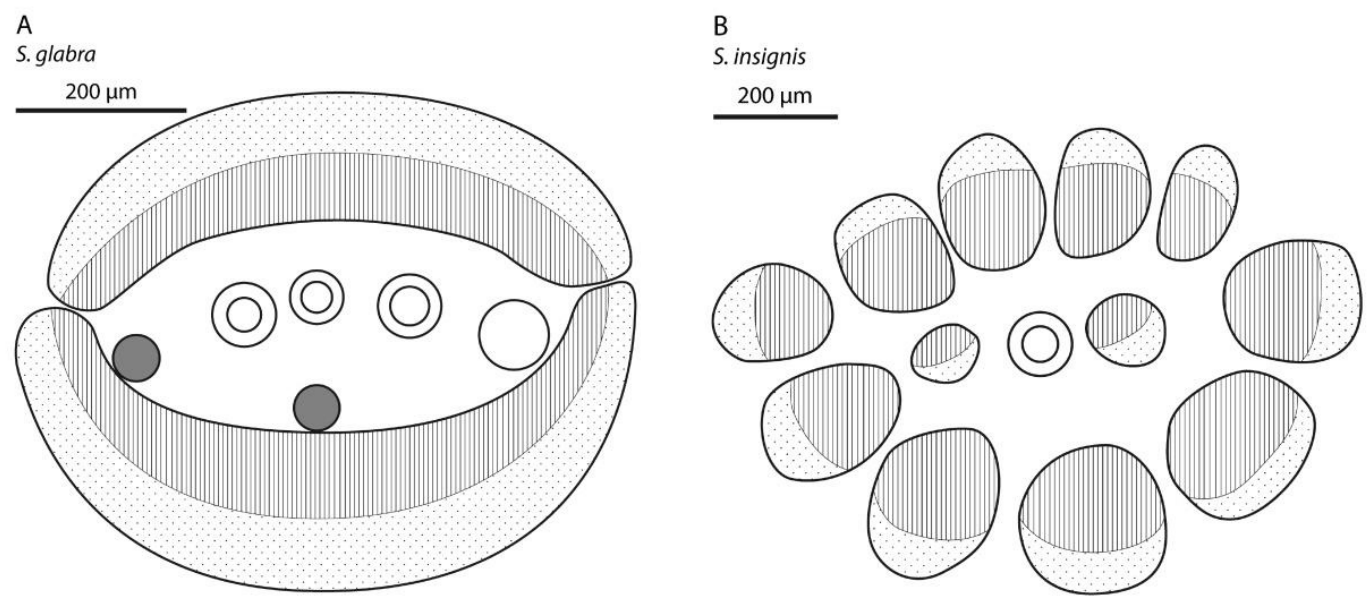

C

S. subcymosa ES 1

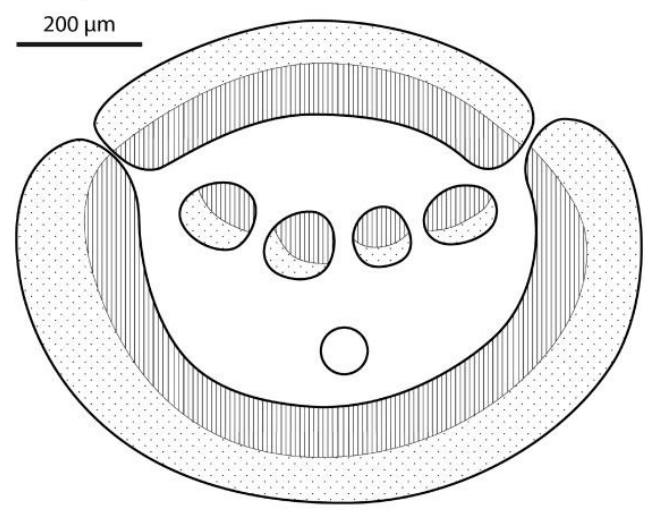

D

S. subcymosa ES 2

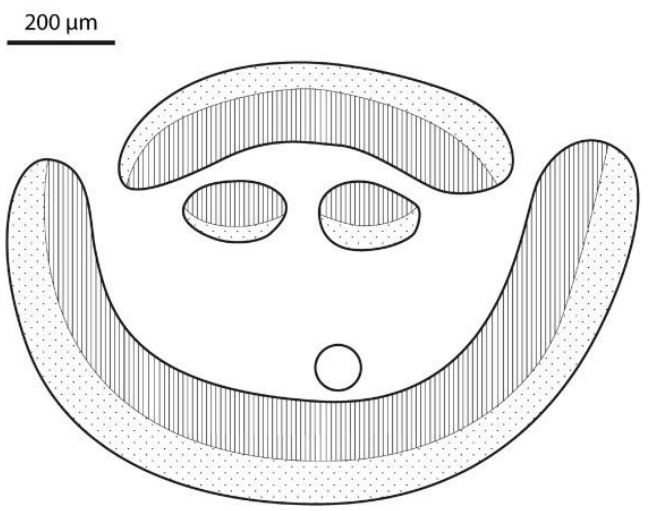

E

S. subcymosa ES 3

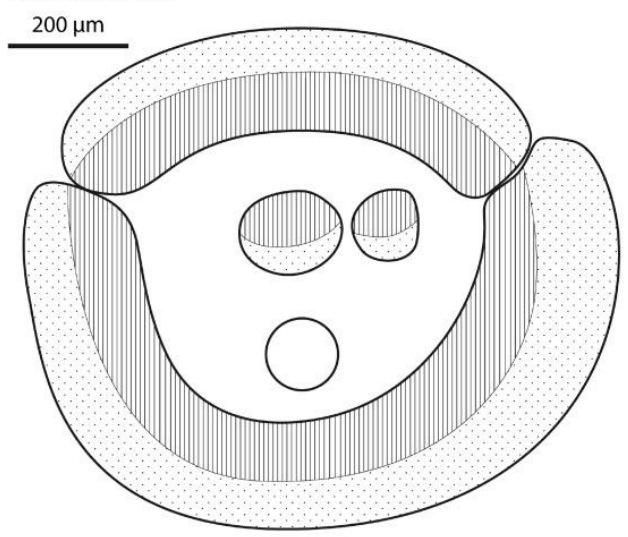

$\mathrm{F}$

S. subcymosa ES 4
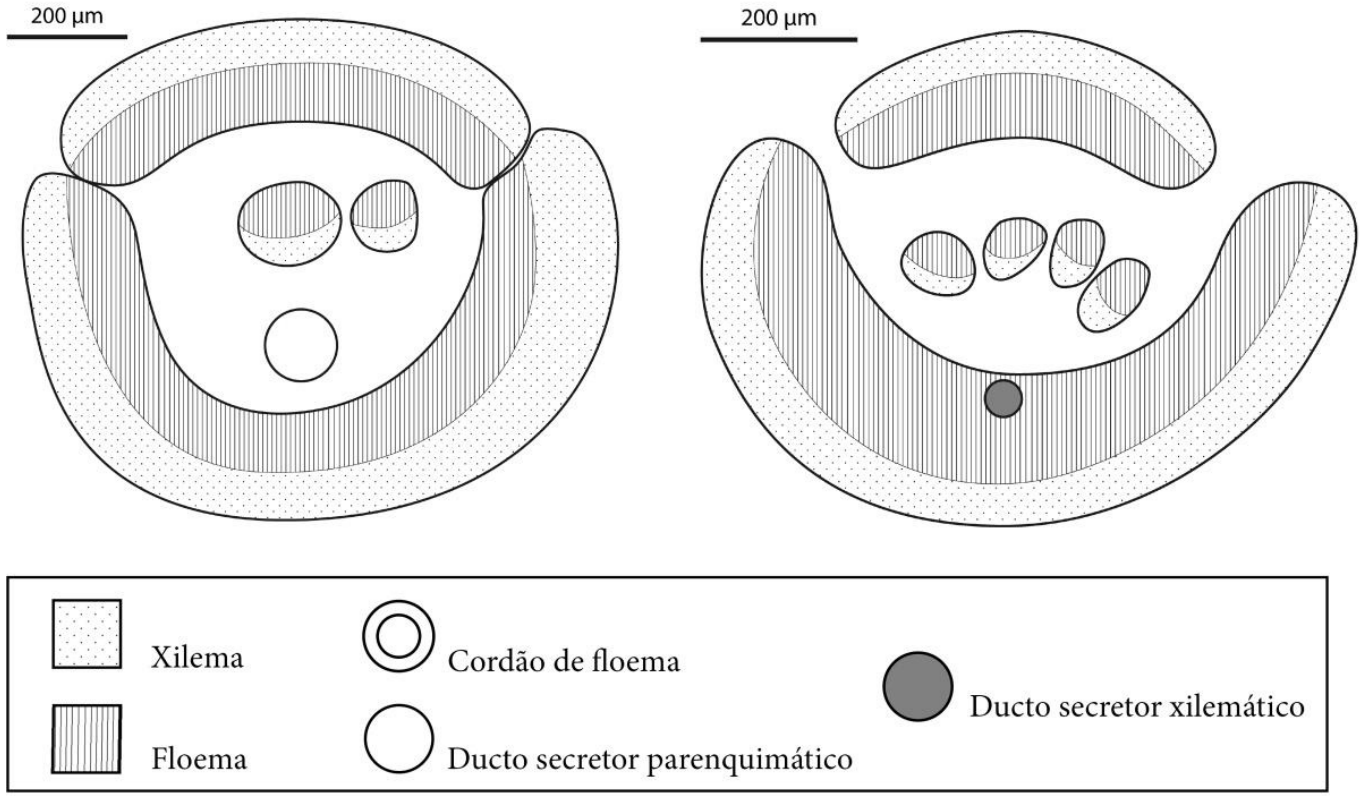
Fig. 3 - Esquema dos padrões de vascularização dos peciólulos nas espécies estudadas.

G

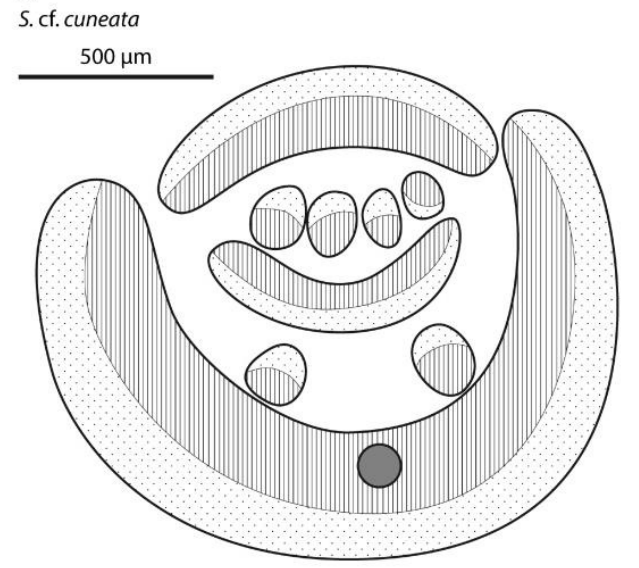

I

Simabasp1

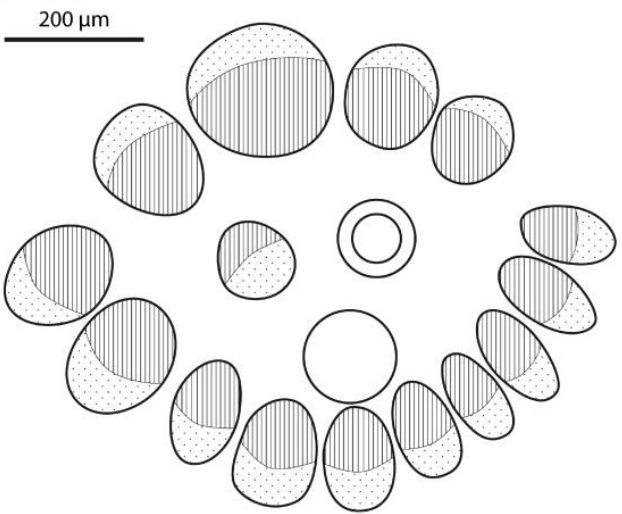

K

S. salubris

$500 \mu \mathrm{m}$

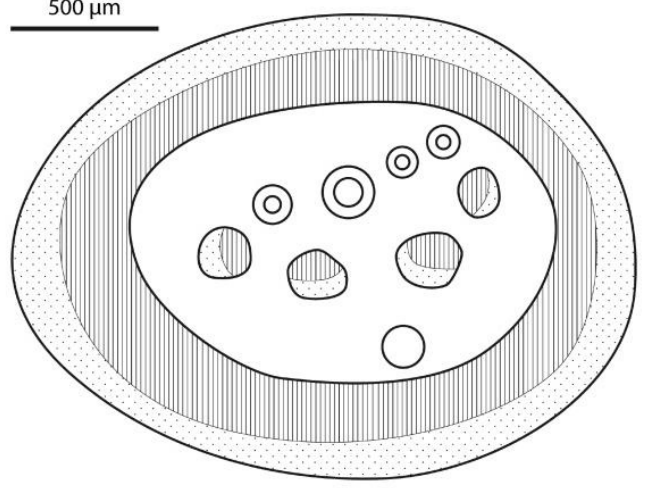

$\mathrm{H}$

S. suffruticosa

$200 \mu \mathrm{m}$

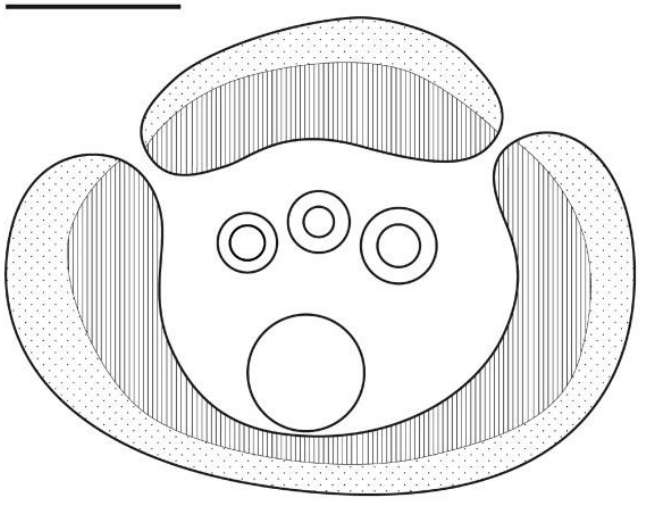

J

S. cedron

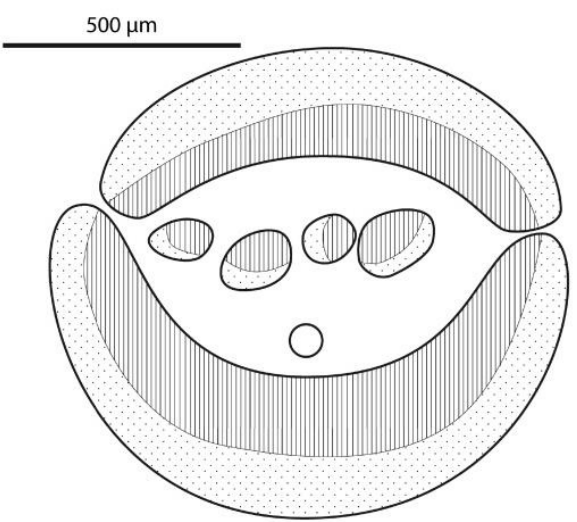

L

S. trichilioides

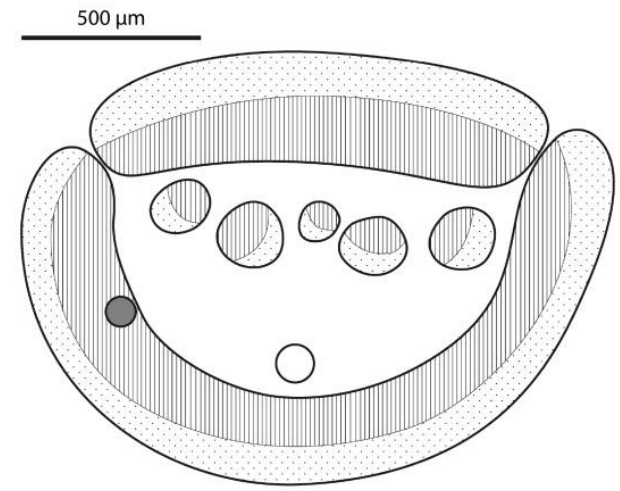

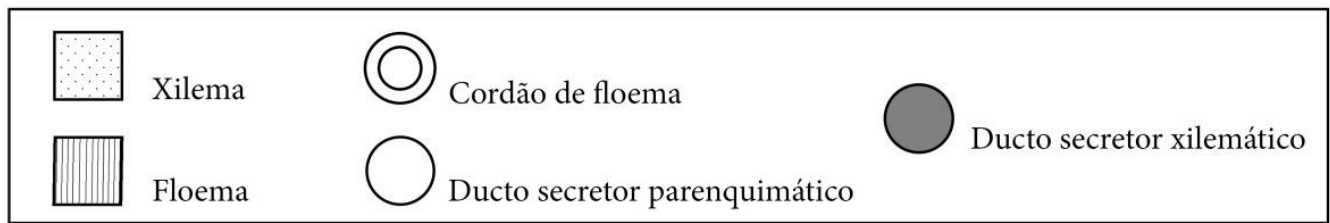


Fig. 4 - Esquema dos padrões de vascularização dos peciólulos nas espécies estudadas.

M

Simabasp2

$200 \mu \mathrm{m}$

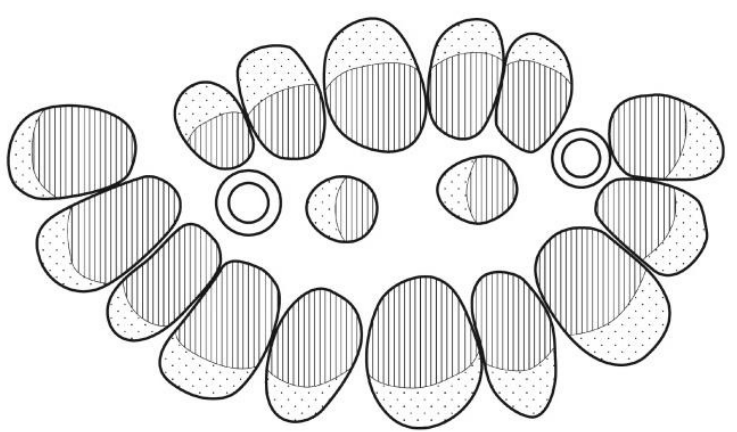

0

S. guianensis AM

$200 \mu \mathrm{m}$

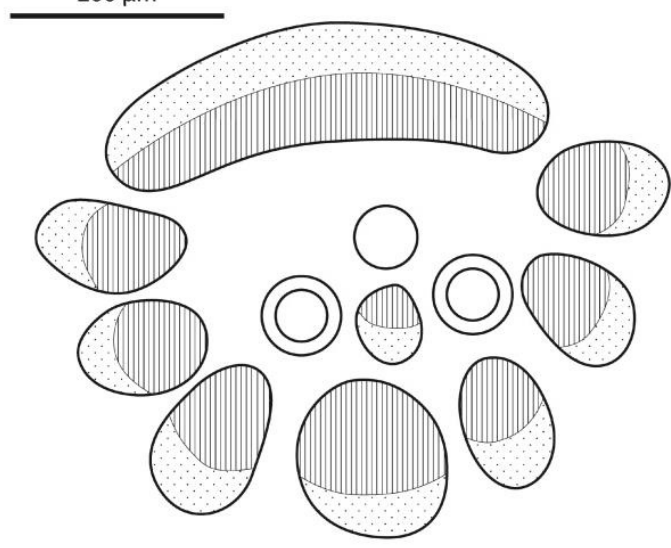

Q

S. polyphylla

$200 \mu \mathrm{m}$
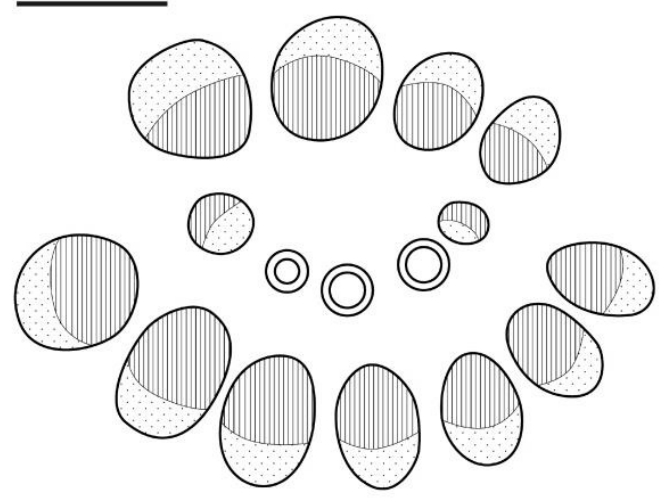

S. guianensis ES

$200 \mu \mathrm{m}$

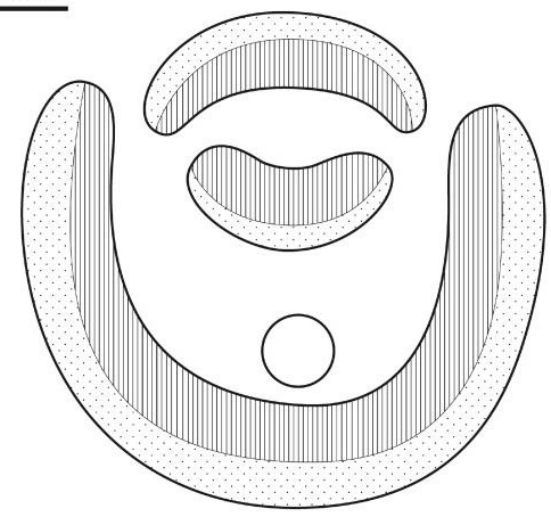

P

S. orinocensis

$200 \mu \mathrm{m}$
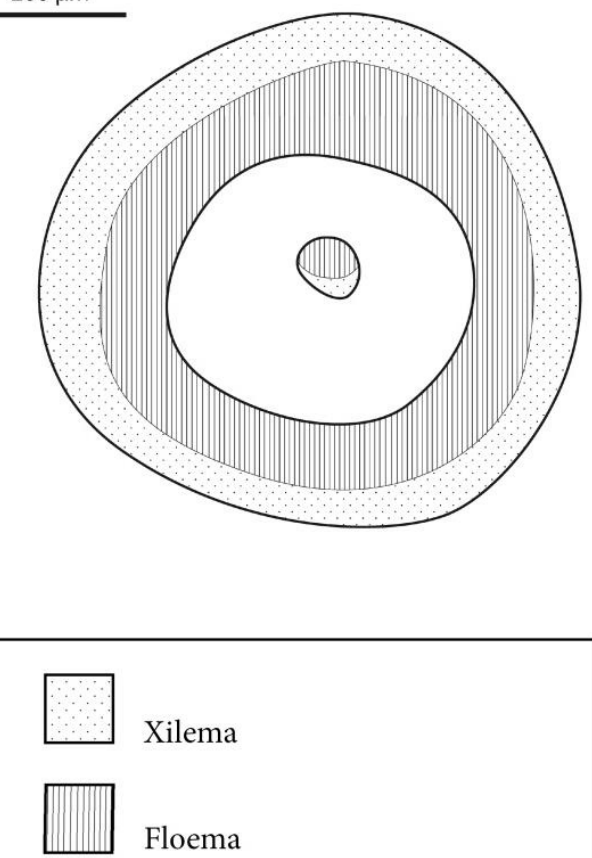

() Cordão de floema

Ducto secretor parenquimático

Ducto secretor xilemático 

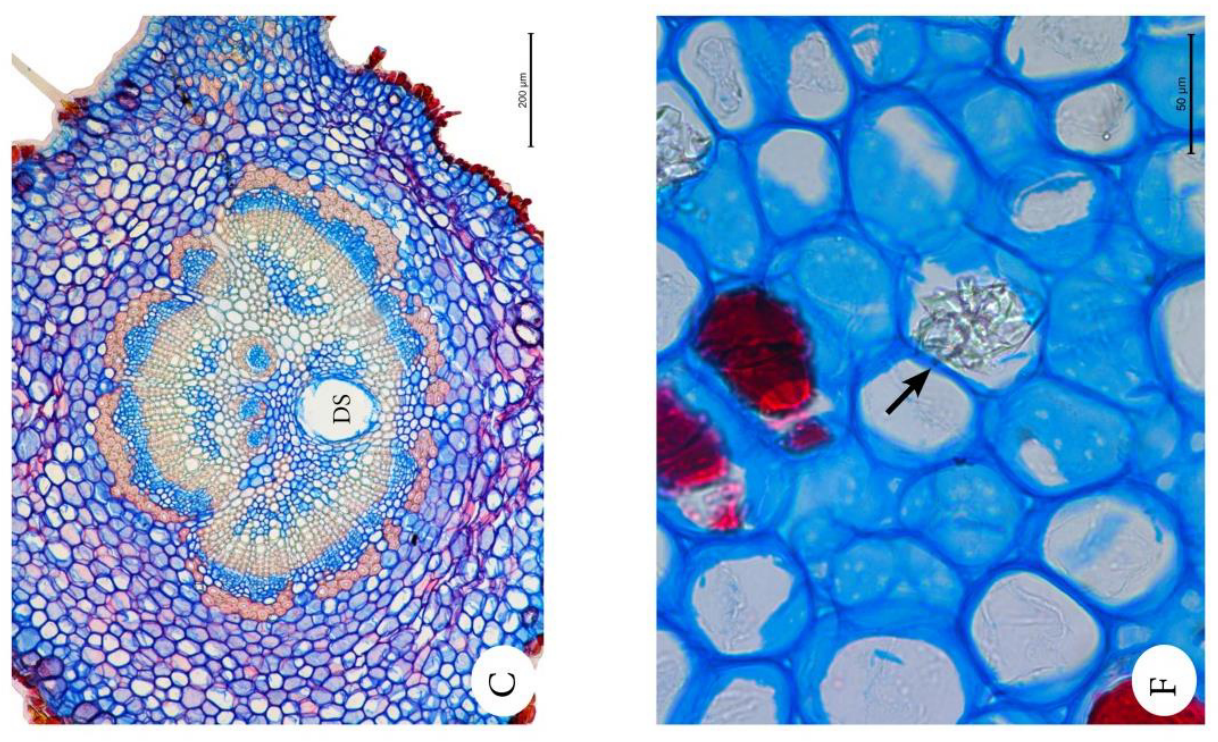

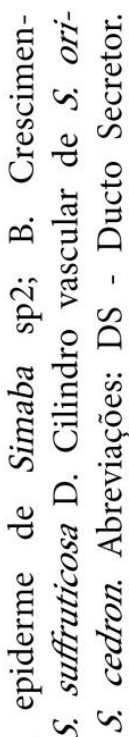
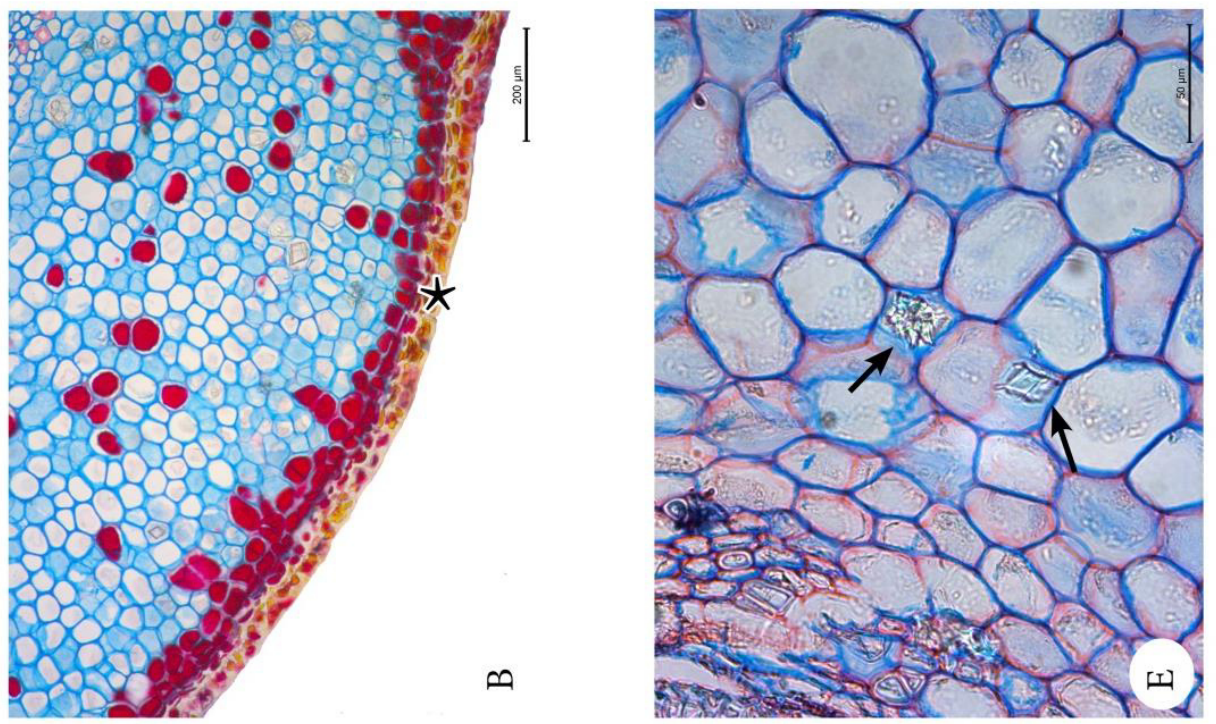

ฐ छ

密

\&

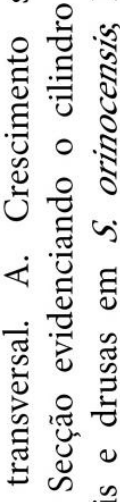
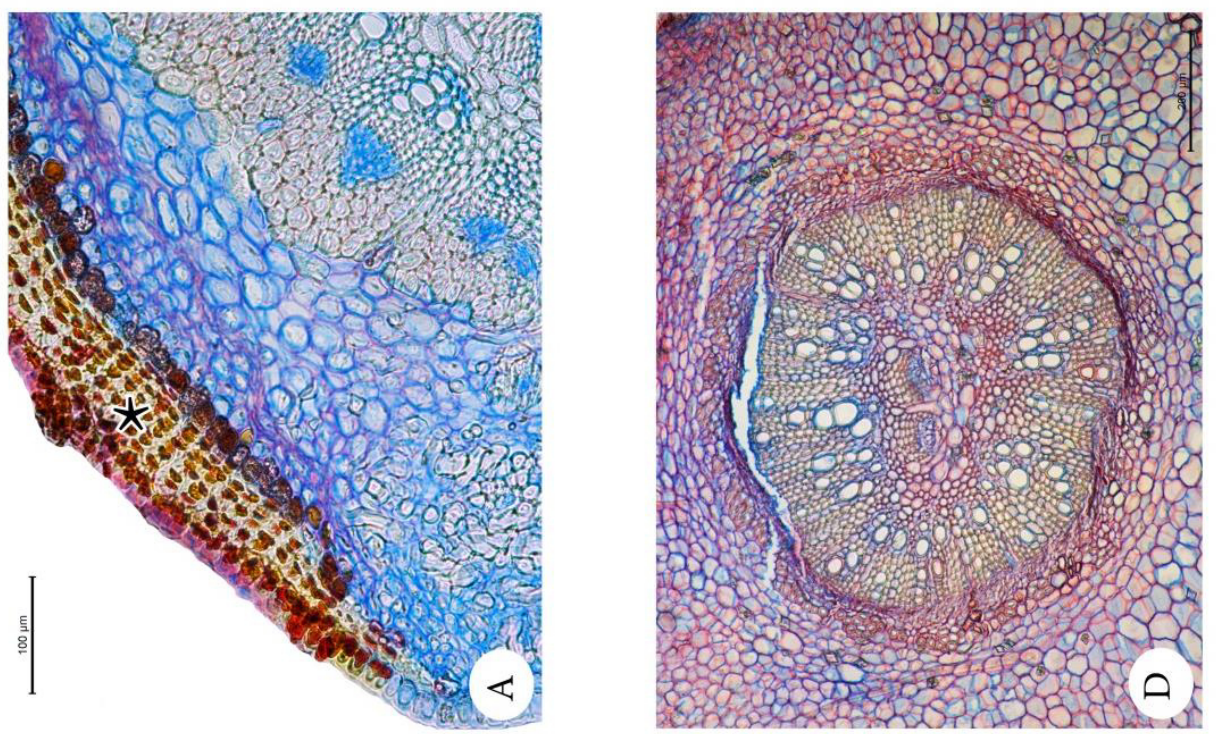

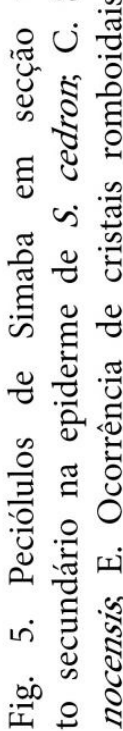




\begin{tabular}{|c|c|c|c|}
\hline 11 & 111111 & 111 & $\Pi \Pi$ \\
\hline 11 & 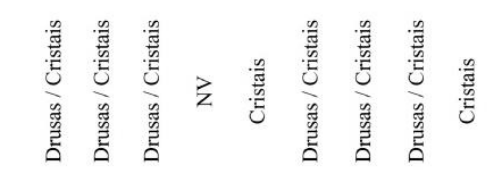 & II & \\
\hline 11 & 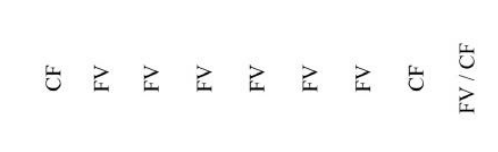 & $=2 \frac{c}{2}$ & \\
\hline & 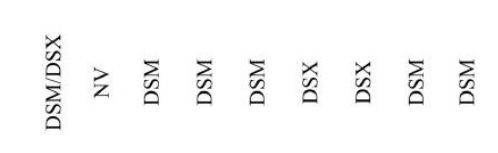 & 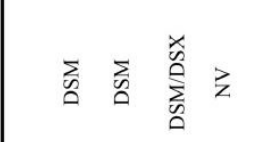 & 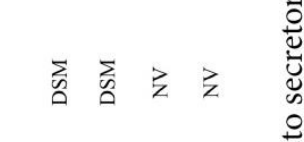 \\
\hline 111 & 11111111 & 1111 & 1111 \\
\hline 111 & 11111111 & I110 & 1111 \\
\hline 11 & blat & $111=$ & 111 \\
\hline 1 & 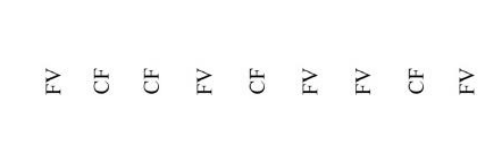 & $\frac{0}{2}=0$ & \|\| \\
\hline & 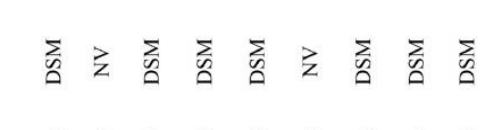 & 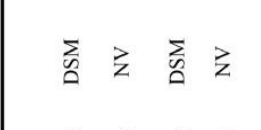 & 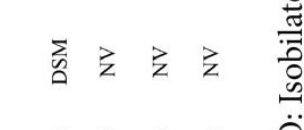 \\
\hline & 111111 & $\| \Perp$ & 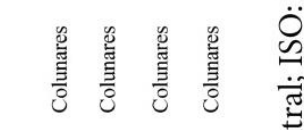 \\
\hline & 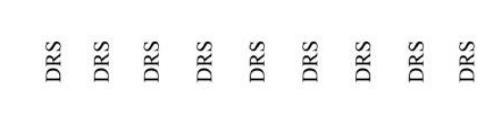 & $\frac{2}{3}$ & 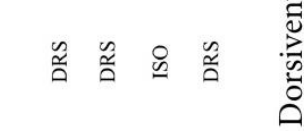 \\
\hline$\| n$ & 11111110 & 13 & 111 \\
\hline & 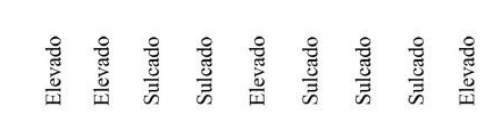 & 111 & 111 \\
\hline & & & \\
\hline & Mn!n! & & \\
\hline
\end{tabular}


Algumas espécies de Simaba têm circunscrição controvertida, dada a ampla variedade morfológica, de habitats e regiões geográficas de ocorrência. Neste estudo foram analisadas quatro amostras coletadas em diferentes regiões do Espírito Santo da espécie S. subcymosa, que possui alta variabilidade macro-morfológica encontrada na mesma área geográfica, em florestas do Domínio da Mata Atlântica. Ao compararmos o grau de variabilidade anatômica encontrado com os caracteres obtidos em $S$. cf. cuneata (táxons estreitamente simpátridos e de difícil distinção), percebe-se que as amostras de S. subcymosa não apresentaram grandes variações estruturais entre si (Fig. 3c - f), mas se diferenciaram muito no padrão de vascularização da amostra de $S$. cf. cuneata. Nesta última espécie, além dos feixes vasculares acessórios no peciólulo, existem placas medulares (Fig. 3g), ausentes nas amostras de S. subcymosa. Isso constitui evidência sustentando a manutenção do reconhecimento de duas espécies distintas, embora semelhantes em muitos atributos morfológicos. Uma avaliação mais ampla, incluindo dados moleculares de populações desses dois táxons deverá auxiliar na resolução desta questão.

Amostras de S. cedron provenientes de diferentes regiões do país também foram analisadas devido à ampla distribuição geográfica desta espécie (a maior dentro do gênero Cronquist 1944; Cavalcante 1983) e também ao seu hábito, que varia de acordo com o habitat e a região, buscando angariar dados que possam subsidiar a reavaliação da circunscrição deste táxon polimórfico e amplamente distribuído. A organização dos feixes vasculares e presença de ductos secretores do peciólulo e nervura central variaram de acordo com a procedência de cada material, indicando a efetiva importância de investigação estrutural detalhada nesta espécie. Para este trabalho foi esquematizado o padrão de vascularização do peciólulo da coleta de Goiás (Fig. 3j).

Fig. 6. Células epidérmicas da lâmina foliolar de Simaba: A. Paredes anticlinais sinuosas de S. cedron e B. S. subcymosa ES2; C. Paredes anticlinais retas de S. orinocensis e D. S. cf. cuneata; E. Paredes anticlinais retas na face abaxial de S. suffruticosa; F. Paredes anticlinais sinuosas na face adaxial de S. suffruticosa. G. Paredes anticlinais sinuosas na face abaxial de $S$. polyphylla;H. Paredes anticlinais retas na face adaxial de S. polyphylla. 

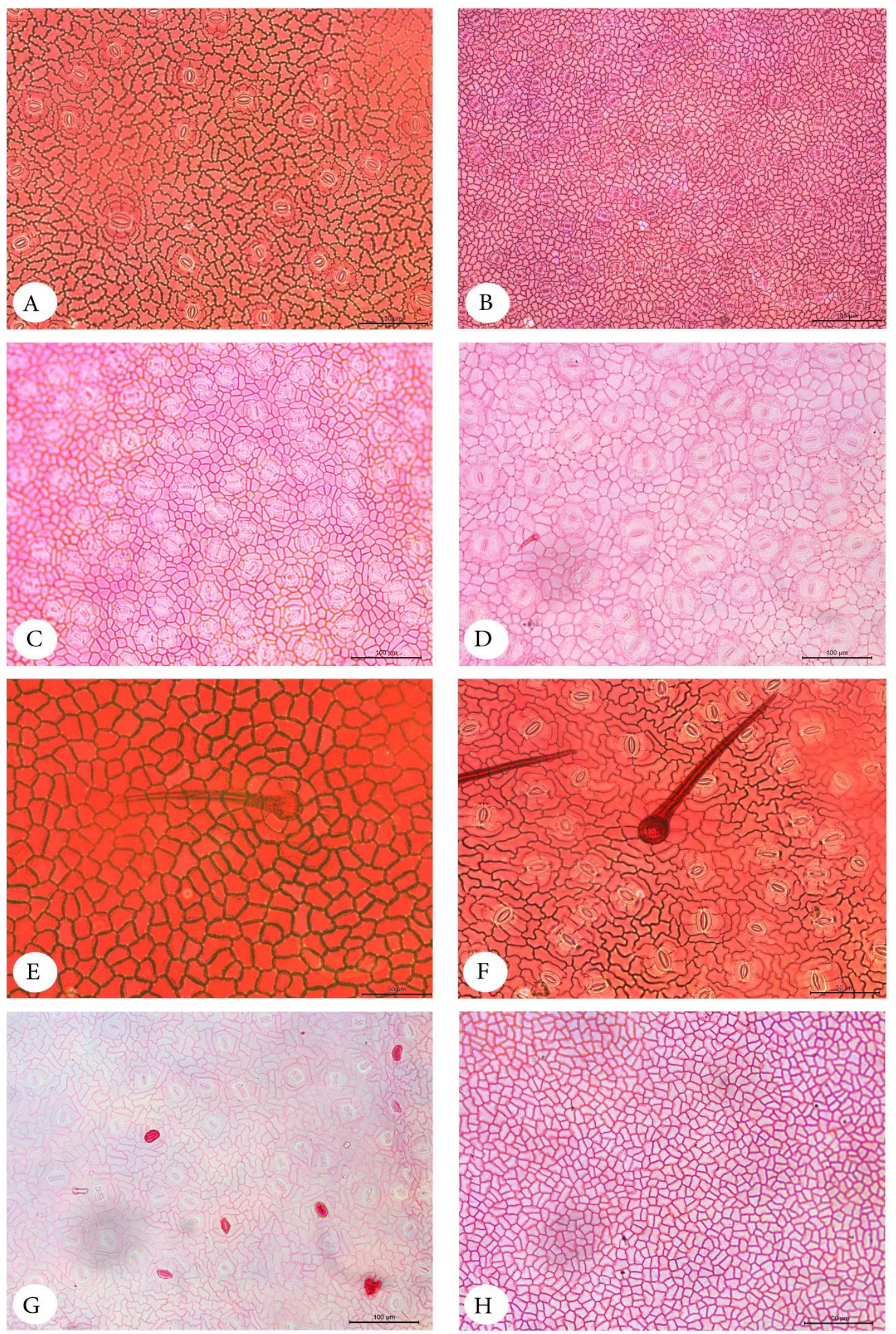


\section{Lâmina foliolar}

A análise dos materiais dissociados mostrou que, em vista frontal, as células epidérmicas em ambas faces da lâmina da maioria das espécies estudadas possuem paredes anticlinais sinuosas em $S$. cedron e $S$. subcymosa ES2 (Fig. 6a, b) e retas nas demais espécies (Fig. 6c, d), exceto $S$. glabra e $S$. suffruticosa que possuem paredes anticlinais retas na face abaxial e sinuosas na adaxial (Fig. 6e, f) e S. polyphylla com a face adaxial reta e abaxial sinuosa (Fig. 6g, h).

Nas espécies analisadas anatomicamente foram visualizados tricomas tectores uni ou multicelulares unisseriados em todas as espécies (Fig.7a, b; 8a), presentes em grande quantidade e distribuídos em ambas as faces por toda a lâmina foliolar (em S. trichilioides) ou escassos e restritos apenas à região da nervura central nas demais espécies estudadas (Fig. 8b, c). Tricomas glandulares capitados foram detectados em $S$. trichilioides (Fig.7, c) e peltados em S. subcymosa (Fig. 8d). Estes tipos de tricomas foram registrados para Simaroubaceae por Metcalfe \& Chalk (1950), e também ocorrem em famílias próximas, como Anacardiaceae, Rutaceae e Sapindaceae (Álvares et al. 2008; Hazel \& Wilkinson 1982; Muntoreanu et al. 2011; Soiís \& Ferrucci 2006).

Metcalfe \& Chalk (1950) descrevem a ocorrência de estômatos quase exclusivamente confinados à face abaxial das folhas de Simaroubaceae, podendo ser paracíticos ou anomocíticos. Todas as espécies estudadas de Simaba possuem folhas hipostomáticas, com estômatos do tipo anomocítico (Fig.6a, f). A posição exclusivamente abaxial dos estômatos na lâmina foliar é associada à proteção contra a alta incidência de radiação solar e à redução da perda hídrica (Turner 1994; Scatena et al. 2005). Quanto à posição dos estômatos na folha, em Simaba estes se encontram no mesmo nível da epiderme e pode estar associado à redução de perda hídrica e controle da transpiração em algumas espécies (Lusa et al. 2014). Nas seções transversais a epiderme é unisseriada em todas as espécies analisadas (Fig. 7a), com células quadradas a retangulares em ambas as faces e papilosas na região da nervura central em todas as espécies, principalmente na face abaxial (Fig. 7b). 


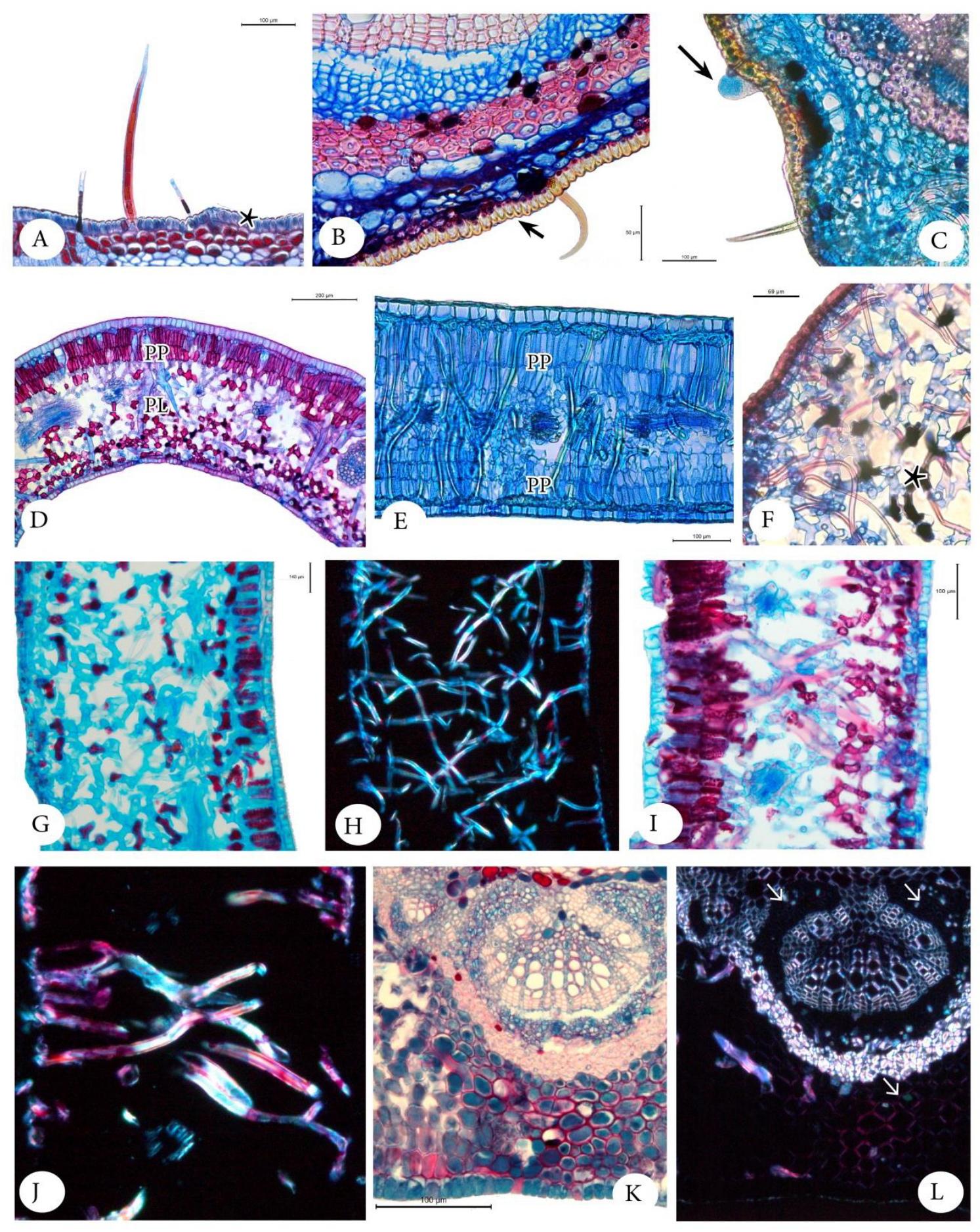

Fig. 7. Mesofilo foliolar de Simaba, secções histológicas: A. Tricoma tector de S. trichilioides evidenciando a epiderme unisseriada; B. Tricoma tector falciforme em $S$. cedron e células epidérmicas papilosas na face abaxial evidenciadas; C. Ticoma glandular capitado em $S$. trichilioides, D. Mesofilo dorsiventral de S. subcymosa ES2; E. Mesofilo isobilateral de Simabasp1; F. Presença de idioblastos com compostos fenólicos em $S$. cedron, G., H. Esclereídes filiformes de $S$. cedron em microscopia óptica e de polarização; I., J. Esclereídes colunares de $S$. subcymosa ES3 em microscopia óptica e de polarização. Abreviações: PP - Parênquima Paliçádico; PL - Parênquima Lacunoso. 

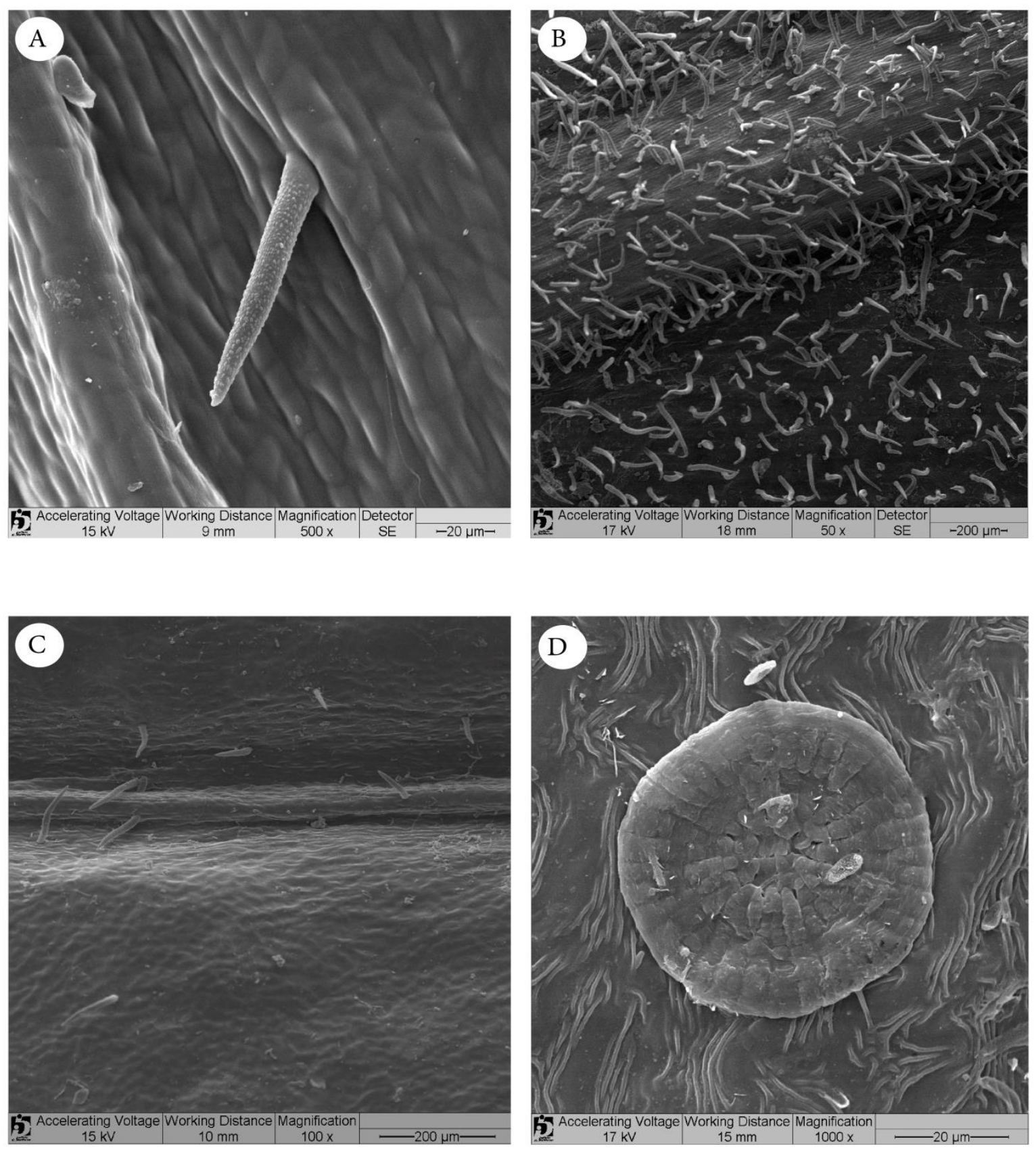

Fig. 8. Tricomas de Simaba. A. Tricoma tector de $\mathcal{S}$. cf. cuneata, imagem obtida em MEV; B. Tricomas por toda a lâmina foliolar em $S$. trichilioides, C. Tricomas restritos à região da nervura central em $S$. cf. cuneata, D. Detalhe de tricoma peltado em $S$. subcymosa. 
O mesofilo é dorsiventral em todas as espécies (Fig. 8d), exceto em Simaba sp1, que apresenta mesofilo isobilateral e duas camadas de parênquima paliçádico (Fig. 7e). As espécies estudadas com mesofilo dorsiventral apresentam de uma a duas camadas de parênquima lacunoso e o parênquima paliçádico varia entre duas a três camadas de células. Isso corrobora o registro de Boas (1913), que encontrou este número de camadas em outras espécies e caracterizou o parênquima lacunoso como "fraco" e o paliçádico como "frouxo", devido aos grandes espaços intercelulares presentes em representantes de Simaba e Simarouba. Visualizamos a presença de compostos fenólicos em muitos idioblastos nas nervuras (Fig. 7f), além de sua presença em células do parênquima paliçádico (Fig. 7d) e lacunoso na maioria das espécies estudadas, exceto em $S$. insignis e $S$. subcymosa ES2, onde estes compostos não foram visualizados. A distribuição e composição dos idioblastos secretores podem apresentar valor taxonômico (Castro \& Machado 2005), e sua ocorrência para alguns membros de Simaroubaceae foi documentada desde a análise anatômica de Boas (1913). Algumas espécies da família foram analisadas quanto à composição destas células secretoras, dado o valor farmacológico do grupo, como em Picrolemma, que apresenta idioblastos taníferos e Quassia, com idioblastos com cristais de oxalato de cálcio (Macedo et al. 2005; Di Sapio et al. 2012). Simaba não possui estudos desta natureza até o momento, mas na presente análise verificamos que, embora sua ocorrência não auxilie na delimitação das seções do gênero, estas células estão presentes em diferentes quantidades com variável distribuição entre as regiões foliolares e peciolulares, indicando que estudos histoquímicos para estas estruturas secretoras são necessários ao grupo.

Esclereídes podem ser encontrados em diferentes partes dos órgãos e tecidos vegetais, além de possuírem grande valor em estudos taxonômicos. $\mathrm{O}$ aumento do tecido esclerenquimático proporciona à planta maior rigidez e resistência dos tecidos vegetais, além de proteção (Turner 1994) e distribuição de luz no mesofilo (Karabourniotis 1998; Bosabalidis \& Kofidis 2002). Em Simaroubaceae a ocorrência de quatro tipos de esclereídes foi documentada em seis espécies de Simarouba (Francheschinelli \& Yamamoto 1993), e dois tipos em Quassia amara L. (Macedo et al. 2005). Em Simaba, Boas (1913) observou a presença de tecido esclerenquimático por todo o mesofilo em sua análise descrita para 17 espécies apontou dois tipos de distribuição deste tecido: espessado, "em pé", atravessando o mesofilo; este observado em S. cuneata, S. cuspidata (atualmente sinônimo de S. guianensis), S. crustacea (atual sinônimo de $S$. orinocensis), S. ferruginea, S. floribunda, S. glabra, S. obovata S. praecox, S. subcymosa, S. suffruticosa e S.warmingiana; e tecido esclerenquimático fino e "deitado", ramificando-se paralelamente à lâmina foliolar, observado em S. cedron, S. glandulifera (atual sinônimo de $S$. insignis), S. maiana, S. pohliana, S. salubris e S. trichilioides. Corroborando parcialmente estes 
dados, as espécies aqui analisadas apresentam esclereídes por todo o mesofilo foliolar. Seguindo a classificação de Esau (Evert 2006), as esclereídes encontradas são do tipo colunar ou filiforme. Os dados apresentados por Boas (1913) são condizentes com os apresentados neste trabalho, exceto para a espécie $S$. insigns. Este autor descreveu o tecido esclerenquimático das espécies como composto por fibras, e neste trabalho o descrevemos como composto principalmente por esclereides, pois são ramificadas e não exclusivamente fusiformes.

Nas espécies de $S$. sect. Grandiflorae as esclereídes são do tipo filiforme (Fig. 7g, h) e do tipo colunar nas espécies de $S$. sect. Floribundae (Fig. 7i, j). Entretanto, em Simaba sp2, espécie nova cuja descrição está em elaboração, foi posicionada em S. sect. Grandiflorae (M. F. Devecchi, com. pess.) embora apresente esclereides colunares. Isso atesta mais uma peculiaridade do novo táxon, além de revelar o quanto poderá ser importante avaliar o papel desses caracteres anatômicos na reavaliação da consistência e circunscrição das duas seções extra-amazônicas de Simaba, que ainda não estão bem delimitadas.

A ocorrência de drusas e cristais romboidais solitários ou agrupados foi registrada em Simaroubaceae por Jadin (1901), Boas (1903) e Metcalfe \& Chalk (1950), sendo os cristais agrupados os mais comuns e variáveis em tamanho. A presença destes cristais proporciona à planta proteção, balanço iônico e rigidez dos tecidos, além da captação e reflexão de luz (Franceschi \& Nakata 2005). Boas (1913) mencionou o tamanho e distribuição destes cristais como caracteres de valor para identificação de gêneros em Simaroubaceae. Observamos em Simaba cristais romboidais solitários em diferentes quantidades, além de drusas de oxalato de cálcio (Fig. 7k, 1), que ocorrem no parênquima ou floema da nervura central das espécies analisadas, mas não foram visualizados em S. subcymosa ES2 e S. suffruticosa. Contudo, nenhum padrão exclusivo foi observado.

O sistema vascular na nervura central é composto por dois semi-círculos (arco aberto e placa dorsal) com crescimento secundário circundados por uma bainha de esclerênquima na maioria das espécies, exceto em S. guianensis (amostras do Espírito Santo e Amazonas) e S. suffruticosa, que apresentam dois grandes conjuntos de feixes vasculares em seu arco principal (esquematizadas na Fig. 9). É constante a ocorrência de colênquima abaixo da epiderme de ambas as faces na nervura central. A ocorrência de cordão de esclerênquima na nervura central e feixes vasculares dispostos em semi-círculos ou círculos descontínuos é reportada também em Quassia e Picrolemma, ambos pertencentes a Simaroubaceae (Saraiva et al. 2002; Macedo et al. 2005). Ocorrem ainda em espécies de Pilocarpus (Rutaceae, Muntoreanu et al. 2011) e de Pistacia (Anacardicaeae, Álvarez et al. 2008), ambas famílias também pertencentes à ordem Sapindales. 
Além disso, a amostra de S. guianensis proveniente do Espírito Santo (padrão 1, Fig. 9) apresentou um tipo de vascularização na nervura central diferente do encontrado na coleta de $S$. guianensis feita no Amazonas (Padrão 2, Fig. 9). Que apresenta um padrão de feixes vasculares individuais localizados próximos uns aos outros, mas que não formam placas nem arcos vasculares. Este resultado sugere que mais estudos devem ser realizados com as populações fortemente disjuntas atualmente tratadas como S. guianensis (Thomas 1985, Pirani \& Thomas 2015), pois elas podem na realidade tratar-se de duas espécies alopátridas. Análises filogenéticas baseadas em dados morfológicos e moleculares de Simaba estão em andamento (M.F. Devecchi, com. pess.) e deverão prover dados robustos para a revisão taxonômica do complexo $S$. guianensis.

A organização do tecido vascular, bem como o número de feixes acessórios ou cordões de floema varia entre as espécies. As espécies Simaba guianensis (Espírito Santo e Amazonas), S. orinocensis e $S$. polyphylla. todas pertencentes a $S$. sect. Tenuiflorae, compartilham a ausência de feixes vasculares acessórios na nervura central. O sistema vascular principal possui crescimento secundário. A relação entre as espécies e a presença ou ausência de feixes vasculares acessórios e cordões de floema, ambos ou ausentes encontram-se na tabela 2.

Visualizamos a presença de ductos secretores medulares na nervura central de algumas espécies envolto por uma bainha com duas a quatro camadas de células parenquimáticas e presença de compostos fenólicos em algumas células (Fig. 9a - c), e algumas espécies sem a presença destes ductos (Fig. 9d, e) Em outras famílias como Anacardiaceae, os ductos secretores também podem ocorrer na medula enquanto que os vasculares ocorrem sempre associados ao floema (Álvarez et al. 2008; Lacchia \& Carmello-Guerreiro 2009). Em Simaba os ductos secretores ocorrem na medula ou no tecido xilemático, nunca no floema. Na nervura dos folíolos também ocorre a presençade cristais romboidais e drusas (Fig. 9f).

Verificamos que existem variações nos padrões de vascularização, esclereídes, quantidade de substâncias fenólicas, tamanho e localização dos ductos secretores na nervura central das espécies estudadas, como o ducto visualizado em S. glabra, que apresenta um tamanho maior em relação aos demais (Fig. 9c). Estes ductos podem, no entanto, não terem sido cortados na região mediana selecionada da nervura dos folíolos, uma vez que não se distribuem ao longo de toda a extensão da nervação (Fig. 9i). 


\section{Padrão 1}

A

S. cedron (238)

$200 \mu \mathrm{m}$

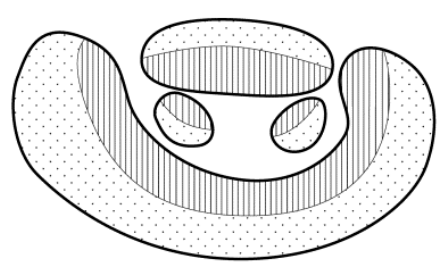

D

S. glabra

$200 \mu \mathrm{m}$

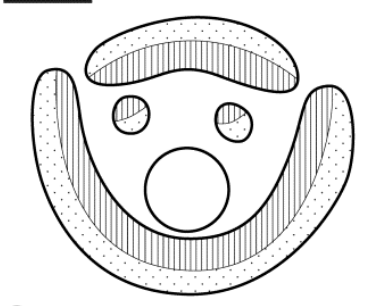

G

S. subcymosa ES2

$300 \mu \mathrm{m}$

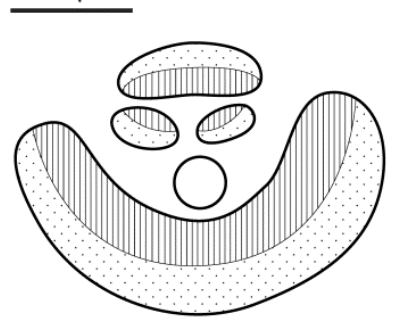

J

S. orinocensis

$200 \mu \mathrm{m}$

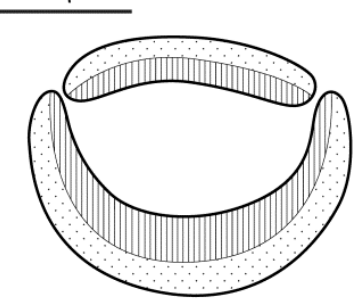

Padrão 2

$M$

Simaba sp2

$200 \mu \mathrm{m}$

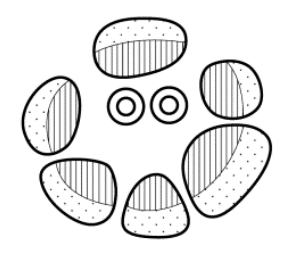

B

Simaba sp1

$69 \mu \mathrm{m}$

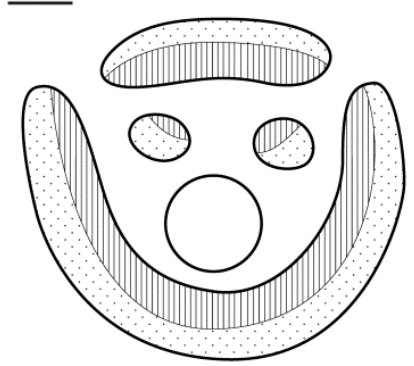

E

S. insigns

$200 \mu \mathrm{m}$

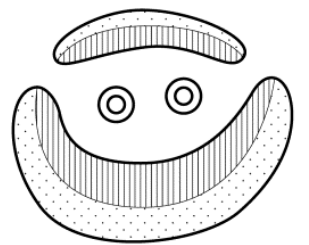

$\mathrm{H}$

S. subcymosa ES3

$300 \mu \mathrm{m}$

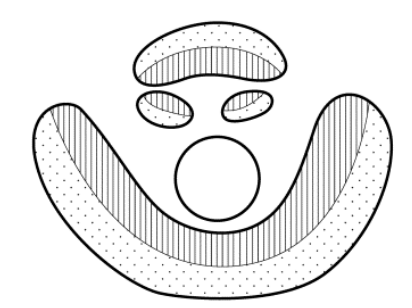

K

S. guianensis ES

$200 \mu \mathrm{m}$

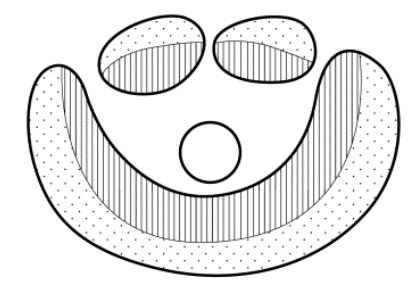

N

S. guianensis AM

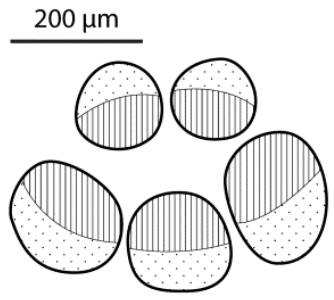

C

S. cf. cuneata

$300 \mu \mathrm{m}$

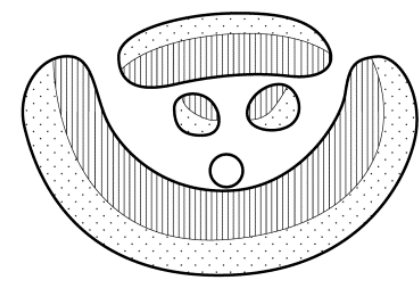

$\mathrm{F}$

S. subcymosa ES1

$200 \mu \mathrm{m}$

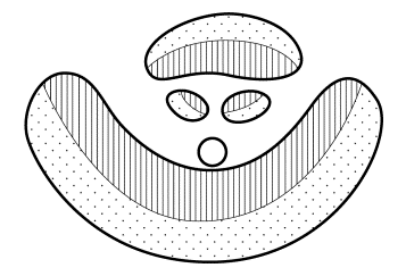

I

S. subcymosa ES4

$200 \mu \mathrm{m}$

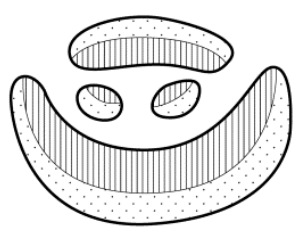

L

S. suffruticosa

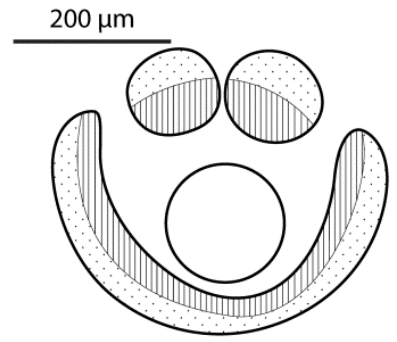

$\mathrm{O}$

S. polyphylla

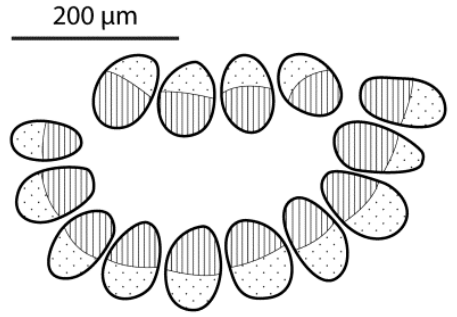

Fig. 9. Esquema dos padrões de vascularização das nervuras centrais nas espécies estudadas de Simaba. 


\section{Ápice foliolar}

No ápice dos folíolos de grande parte das espécies estudadas de Simaba existe uma glândula proeminente cujo tamanho varia de espécie para espécie, até mesmo no mesmo indivíduo (Fig. 11a-c), sendo bem desenvolvidas principalmente em indivíduos jovens (Fig. 11d). A presença desta glândula apical foi apontada por Engler (1931), Boas (1913), Metcalfe \& Chalk (1950) e Cavalcante (1983), mas a natureza da secreção nunca foi elucidada. O teste com glicofita nas secreções presentes nestas estruturas produziu resultado positivo para a presença de glicose, indicando que as mesmas são nectários extraflorais, que podem ser do tipo elevado ou sulcado (Bentley \& Elias 1983).

Os tipos de nectários extraflorais de cada espécie encontram-se na tabela 2. As secções longitudinais destes nectários revelaram tecido secretor composto por algumas poucas células epidérmicas que em muitas espécies são papilosas (Fig. 11e) e possuem uma grande quantidade de parênquima nectarífero, cujo conjunto forma um aglomerado esférico de células secretoras globular (Fig. 11f - h) ou dispõe-se formando três cordões que divergem em direção à base da folha - ramificado (Fig.11 i, j). O parênquima nectarífero é envolto por idioblastos com compostos fenólicos e vascularizado por xilema e floema. Os feixes vasculares possuem suas terminações na periferia dos idioblastos com compostos fenólicos (Fig. 11k).

A epiderme nectarífera libera o néctar para o ambiente através de um canal central ou lateral formado pela invaginação da superfície do nectário (Fig. 11h). Embora o nectário apical não seja proeminente em todos os folíolos, ele foi identificado em todas as espécies analisadas. Simaba glabra apresenta a ocorrência de ductos secretores em meio ao parênquima nectarífero, característica visualizada apenas nesta espécie (Fig. 111).

Nectários extraflorais são comuns na família Simaroubaceae, tendo sido documentados na face adaxial da lâmina foliar de Samadera e Quassia, nos pecíolos de Cadellia e na margem foliolar de quase todas as espécies de Ailanthus (Bentley \& Elias 1983). Embora muito presentes na família, o estudo destas estruturas ainda não foi explorado nas espécies de Simaba.

Também há referências de nectários foliares em outras famílias da ordem Sapindales. Algumas Anacardiaceae possuem nectários na parte superior do pecíolo ou entre ele e a lâmina, nas brácteas e estípulas. Nectários foram também reportados para a face abaxial das folhas de Meliaceae e em algumas espécies de Zanthoxylum (Rutaceae) (Bentley \& Elias, 1983). 
Fig. 10. Nervura central dos folíolos de Simaba, secções histológicas: A. Ducto secretor em S. guianensis ES; ocorrência de idioblastos com compostos fenólicos evidenciada; B. Ducto secretor em S.suffruticosa; ocorrência de idioblastos com compostos fenólicos no parênquima paliçádico evidenciada C. Ducto secretor maior em relação aos demais em S. glabra; D. Ausência de ductos secretores em S. cedron e E. em S. subcymosa ES3; F. Cristais romboidais em S. glabra; G. Detalhe de ducto secretor de S. subcymosa ES3 e H. em Simaba sp1; I. Ducto secretor na nervura do folíolo diafanizado de S. glabra, evidenciando sua curta extensão. Abreviatiras: FV - Feixe Vascular.

A ocorrência de nectários em folhas tem sido objeto de muita investigação e discussão. Esse tipo de glândula tem sido denominado nectário extrafloral, e sua função desperta controvérsias. Existem muitas evidências corroborando um hipotético papel de proteção da planta contra patógenos e herbívoros, propiciada pelas formigas que forrageiam esses nectários (Bentley 1977; Koptur, 1979; Schemske 1980; Keeler \& Kaul 1984; Fahn 1988). Bentley (1976) sugeriu que o número de plantas com nectários extraflorais é maior em áreas perturbadas. Em algumas populações de Simaba observadas a campo (S. trichilioides em Goiás, S. cedron no Espírito Santo), verificamos intensa atividade de formigas nos nectários, gemas axilares e pecíolos de folíolos jovens e, sobretudo nos das pequenas brácteas presentes na base e ao longo da inflorescência (Fig. 12a, b, c, e, f), desde as fases iniciais de desenvolvimento (Fig. 12d, g). Alguns autores afirmam que os nectários foliares estariam relacionados com a função fisiológica de secretar excesso de açúcares produzidos na fotossíntese, contribuindo para a redução da atividade fotossintética da planta. Bory \& Maczulatjys (1990) realizaram análise de ultraestrutura em nectários foliares de Ailanthus glandulosa Desf., gênero de Simaroubaceae, e indicaram que, além desta função, possam ocorrer variações nas atividades destes nectários de acordo com fatores externos (variações sazonais, estresse hídrico e remoção destes nectários e seus efeitos na fisiologia da folha).

Além do nectário extrafloral localizado no ápice foliolar, verificamos aqui pela primeira vez a presença de glândulas secretoras distribuídas em outras partes da lâmina. Embora presentes na maioria das espécies de Simaba por toda a lâmina foliolar, ao longo da margem ou próximo à base da lâmina base da lâmina (Fig. 13a), essas estruturas nunca foram investigadas quanto à sua 

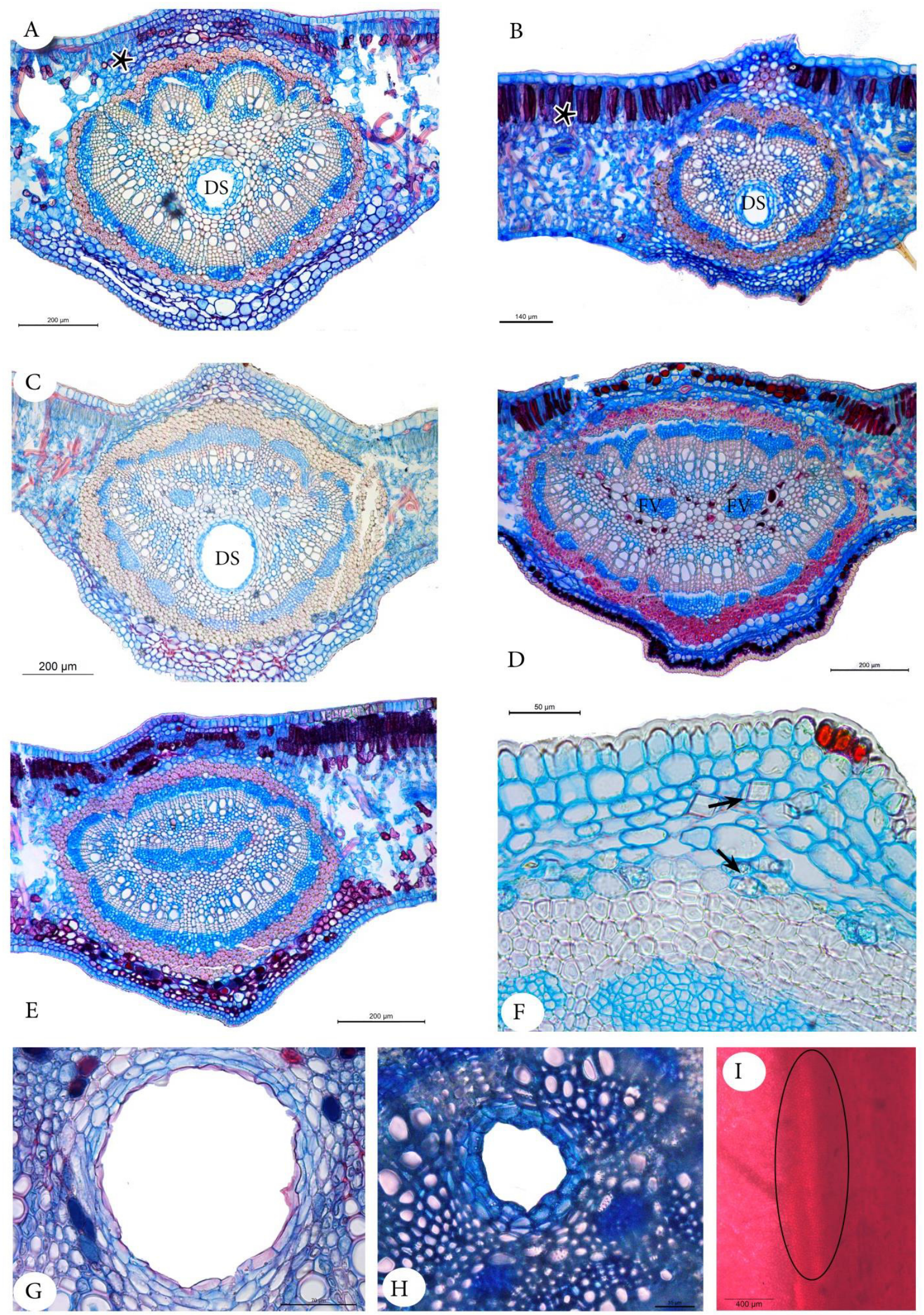

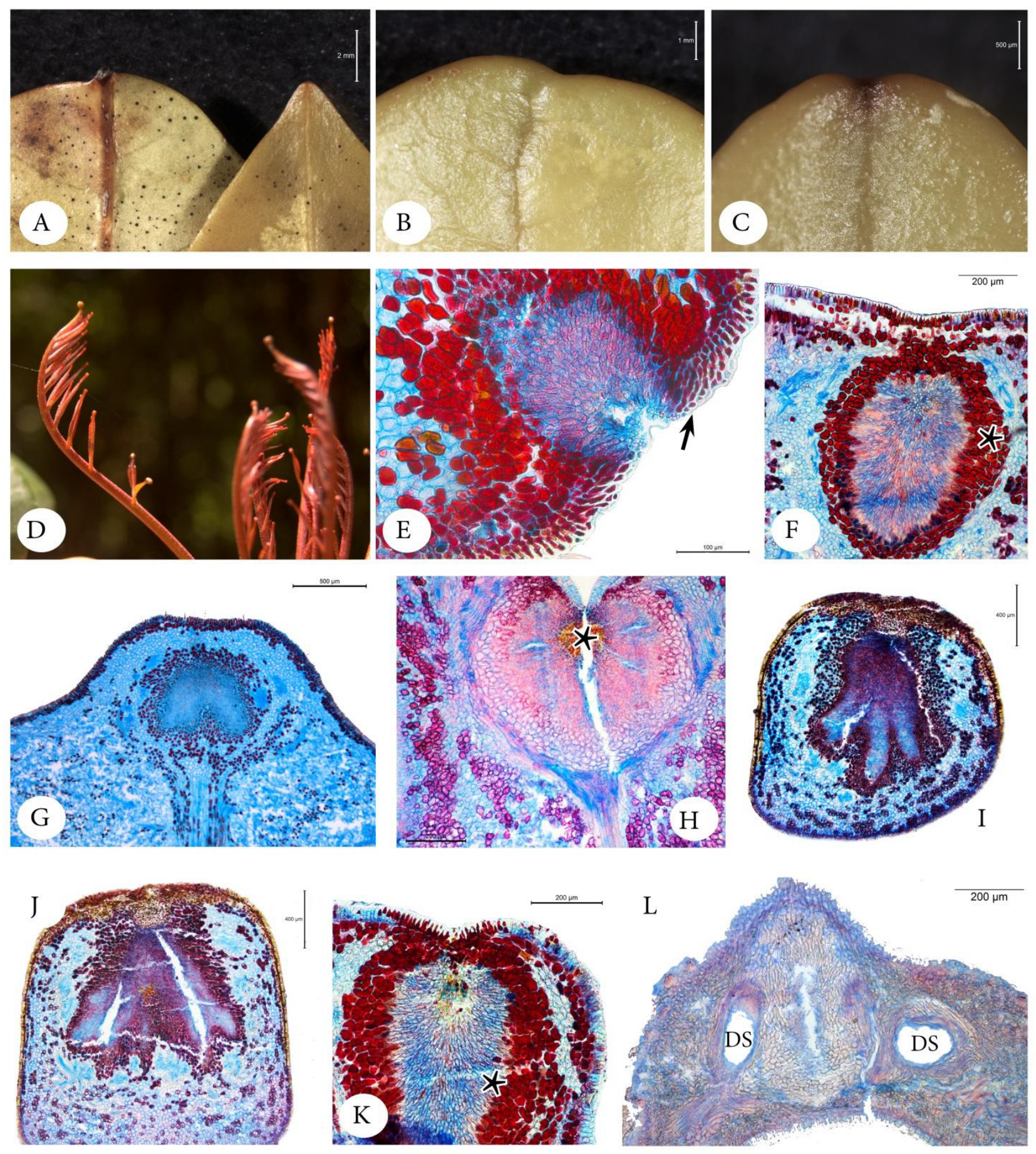

Fig. 11. Nectários extraflorais no ápice foliolar em Simaba: A. Folíolos de S. salubriscom e sem o nectário extrafloral evidente e B, C. em Simabasp2; D. Nectários evidentes em folíolos jovens de $S$. insignis, E. Epiderme com células papilosas em secção histológica de $S$. trichilioides, F. Parênquima nectarífero em disposição globular em $S$. subcymosaES1, em G. S. trichilioidese H. em S. subcymosaES2, com invaginação da superfície do nectário evidenciada; I, J. Parênquima nectarífero em disposição ramificada em $S$. cedron, K. Feixes vasculares com terminações na periferia dos idioblastos com compostos fenólicos em $S$. cedron, L. Ductos secretores no nectário apical de $S$. glabra. Abreviaturas: DS - Ducto Secretor. Foto (D.) de M.F. Devecchi. 

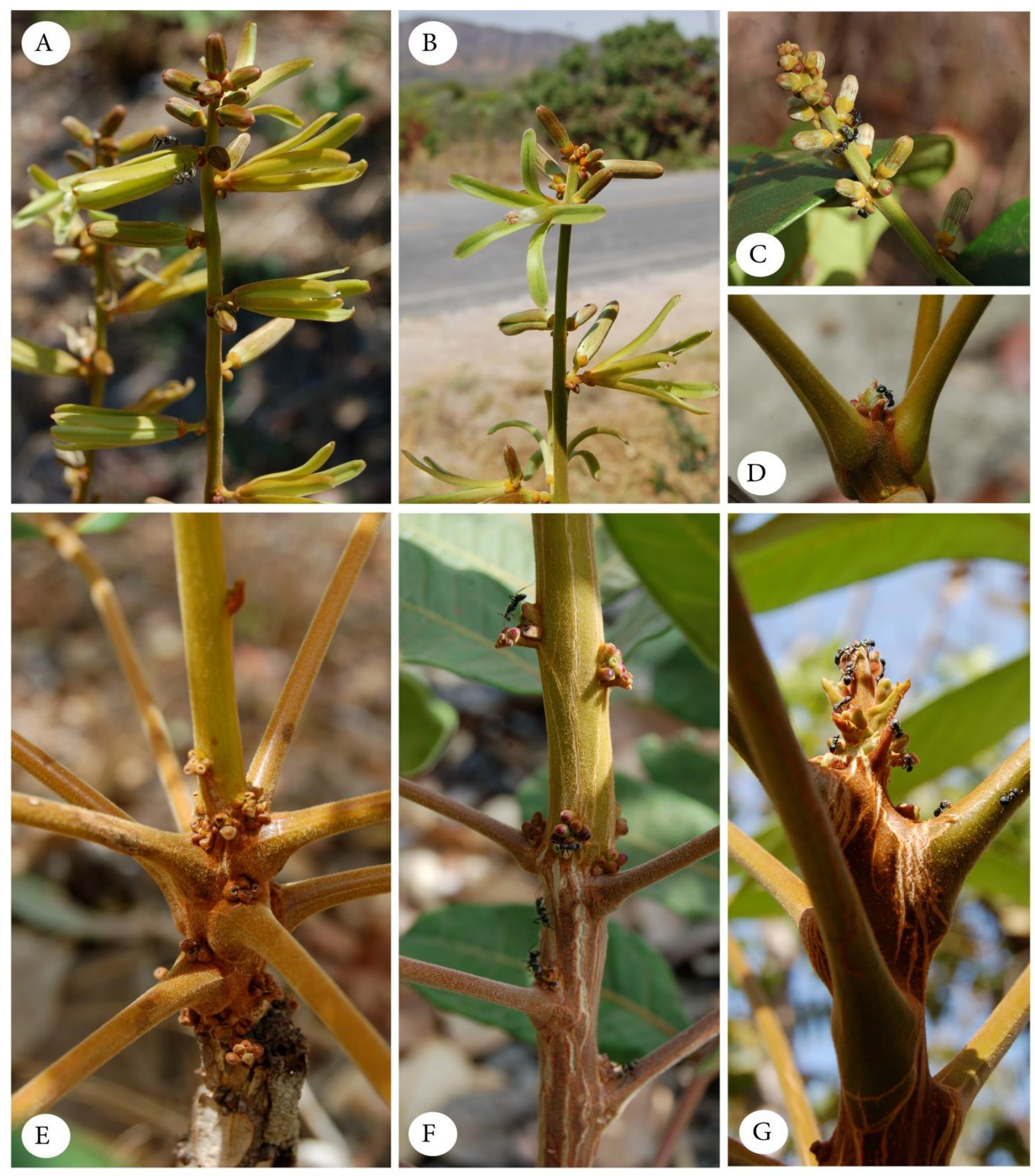

Fig. 12. Nectários extraflorais em Simaba. A. Parte distal da inflorescência de S. trichilioides, com brácteas modificadas em nectários sendo forrageadas por formigas; B, C. Distribuição de brácteas modificadas em nectários junto à inserção das flores de $S$. cedron, D, E. Nectários na base dos pecíolos (junto às gemas axilares) de $S$. trichilioides, F. Formigas forrageando os nectários junto à base dos pecíolos de $S$. trichilioides, G. Nectários nos estágios iniciais de desenvolvimento da inflorescência de $S$. cedron, visitados por formigas. Fotos de M.F. Devecchi. 
composição tecidual nem natureza secretora. Elas são visualizadas sob estereomicroscópio ou mesmo à vista desarmada e só não foram detectadas por este exame simples em S. suffruticosa. Neste trabalho testamos com glicofita o exudato presente em glândulas dos folíolos de S.obovata, confirmando a presença de glicose e caracterizando-as também como nectários extraflorais (Fig. 13b-d).

Os cortes longitudinais das glândulas presentes na base da lâmina foliolar de $S$. orinocensis mostraram grande semelhança estrutural com os nectários extraflorais presentes no ápice dos folíolos. Estas glândulas ocorrem em números de um a dois pares em ambos os flancos da base laminar do folíolo (Fig. 13e), que apresenta uma depressão na região da glândula (Fig. 13c, f). Seu tecido secretor é globular e mostra uma abertura central voltada para a face adaxial da lâmina (Fig.13h - k). Na espécie S. obovata, a presença destes nectários é mais esparsada em relação aos de S. orinocensis (Fig. 13b).

Trabalhos buscando evidências sobre a natureza e funções dos nectários extraflorais são de grande importância. Em Simaba seria interessante investigar melhor a distribuição espacial dos nectários apicais e marginais, sua anatomia e histoquímica e avaliar aspectos da alocação dos recursos dos nectários, sobretudo em quais circunstâncias a planta os aloca em secreções ou reservas e de que forma estes eventos estão ligados a seu crescimento e reprodução.

\section{Venação}

Boas (1913) referenciou o padrão de venação para a família como sempre pinado, comumente camptódromo; O padrão primário de venação de todas as espécies estudadas de Simaba é pinado, com uma nervura basal e a venação secundária do tipo broquidódroma, com angulação inconsistente (Fig. 14a). Este padrão de venação secundário é encontrado também em Simarouba, como visualizado na diafanização de Simarouba amara. Foi verificada a presença de venação inter-secundária com espaços irregulares em todas as espécies analisadas, com direção proximal e distal de tamanho superior a $50 \%$ em relação à secundária (Fig. 14b). A venação terciária é alternada percurrente (Fig. 14c) e a venação quaternária é livremente ramificada com nervuras terminais livres dicotômicas (Fig. 15d).

A presença de aréolas é fracamente desenvolvida nas espécies estudadas, não sendo suficientemente visualizadas. Até o momento não havia dados disponíveis sobre o padrão de venação foliar de Simaba, que se mostrou constante em todas as espécies analisadas. 

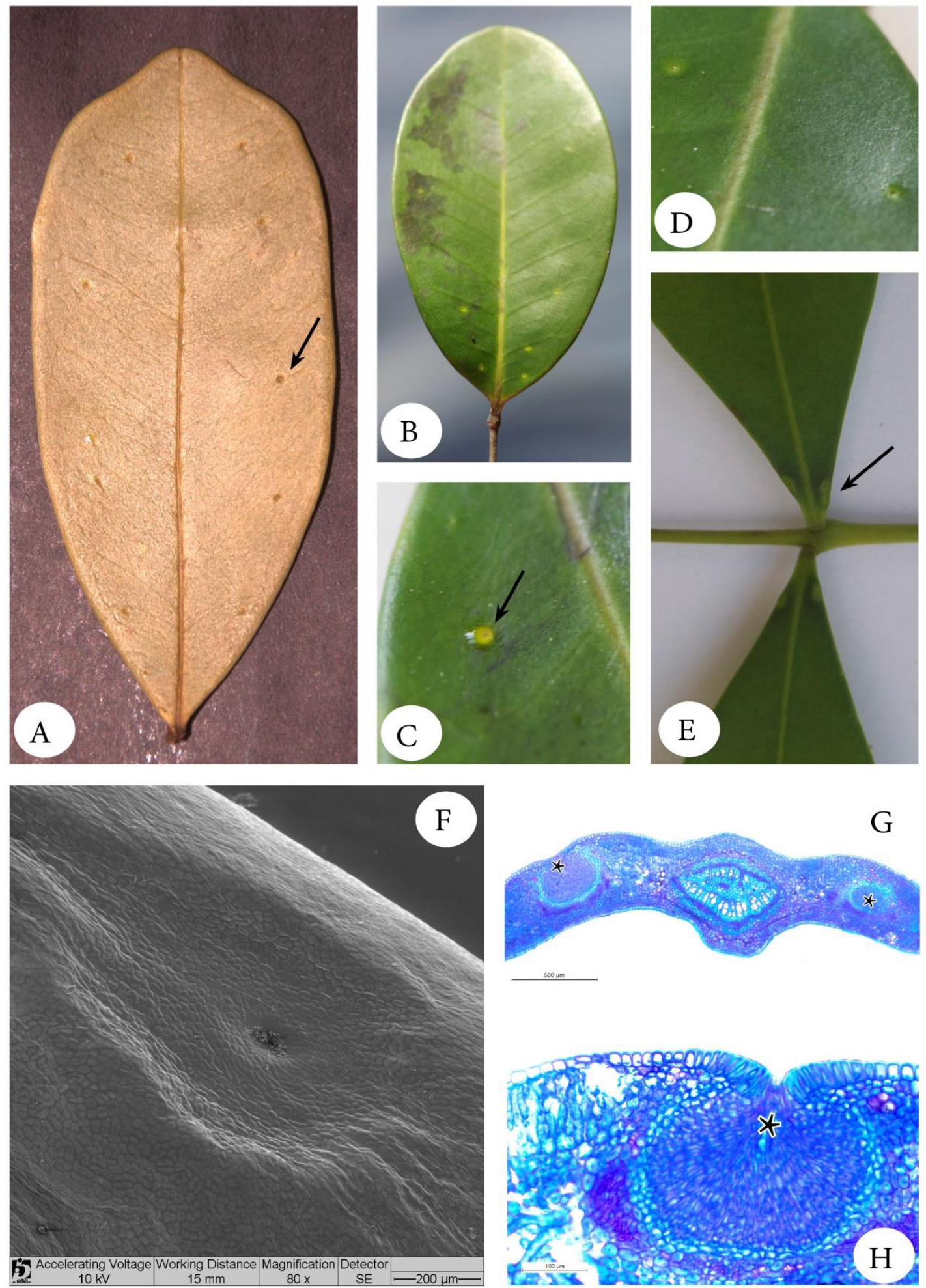

Fig.13. Nectários extraflorais nos folíolos de Simaba: A. Nectários distribuídos por toda a lâmina foliolar em $S$. subcymosa ES3; B. Distribuição mais restrita à área proximal da lâmina em S. obovata; C, D. Detalhes do exudato no nectário extrafloral sulcado na lâmina de S. obovata; E. Pares de nectários entre a base da lâmina e o peciólulo em S. orinocensis; F. Nectário sulcado em S. orinocensis, imagem em MEV; G. Secção transversal da região basal de folíolo com nectários extraflorais (com tecido secretor globular) evidenciados; H. Detalhe da invaginação da superfície do nectário. 

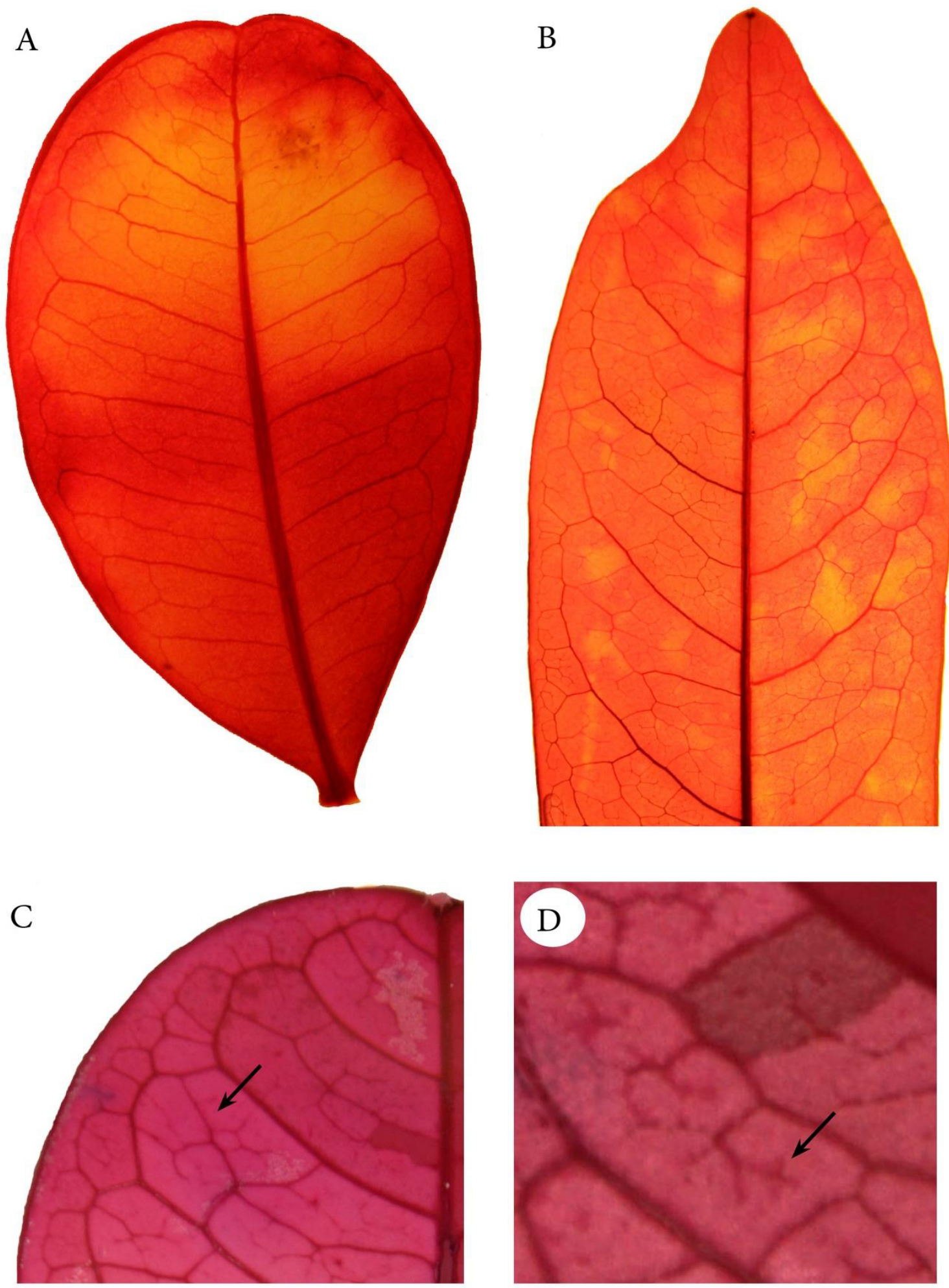

Fig. 14. Padrões de venação nos folíolos de Simaba. A. Nervação secundária broquidródroma em Simaba floribunda, B. Nervação terciária intercostal percurrente em $\mathcal{S}$. salubris, C, D. Nervação quaternária livremente ramificada em S. pohliana, a seta aponta a terminação livre dicotômica. 


\section{Considerações Finais}

Os avanços para aprimorar o conhecimento da morfologia das espécies de Simaba têm ocorrido de modo lento, uma vez que receberam o último tratamento taxonômico há mais de 30 anos (Cavalcante1983) e anatômico há mais de 100 (Boas 1913). Desde então as adições de dados estruturais sobre este grupo foram poucas e pontuais. Neste trabalho conseguimos analisar os dados já disponíveis para o gênero e documentar a anatomia foliolar de mais da metade das suas espécies, trazendo características inéditas para o grupo, como o padrão de venação dos folíolos que, embora não tenha apresentado variações infragenéricas, ainda não havia sido estudado. Os folíolos isobilaterais, observados em Simaba sp1, constituem caráter já referenciado por Metcalfe \& Chalk (1950) como de rara ocorrência em Simaroubaceae. A caracterização das glândulas apicais dos folíolos da maioria das espécies de Simaba como nectários extraflorais aqui realizada constitui outra contribuição relevante para o melhor conhecimento do gênero, com destaque para a descoberta de nectários extraflorais nas margens laminares e base foliolar. A ocorrência exclusiva de esclereídes filiformes em espécies pertencentes a $S$. sect. Grandiflorae reforça a possibilidade deste grupo com flores e porte maiores serem de fato um grupo monofilético; entretanto Simaba sp2, espécie nova em fase de descrição, será incluída nessa seção pelas características florais, mas possui esclereídes colunares, o que mantém a questão da reavaliação das seções controvertida. A ausência de feixes vasculares acessórios na nervura central de todos os membros estudados da S. sect. Tenuiflorae pode reforçar a hipótese de Boas (1913) de que esta seção seria um grupo efetivamente distinto das outras duas seções, o que também é sustentado na filogenia parcial de Simaba (Clayton 2007), onde esta seção emerge como grupo monofilético. Os dados levantados neste estudo auxiliam a melhor caracterizar a estrutura foliar dos representantes de Simaba, evidenciando caracteres que podem ser significativos para aprimorar a circunscrição das espécies, subespécies e seções do grupo. Ademais, muitos dos atributos encontrados e suas variações instigam a elaboração de hipóteses sobre como se deu a evolução das estruturas e a diversificação desse gênero neotropical. 


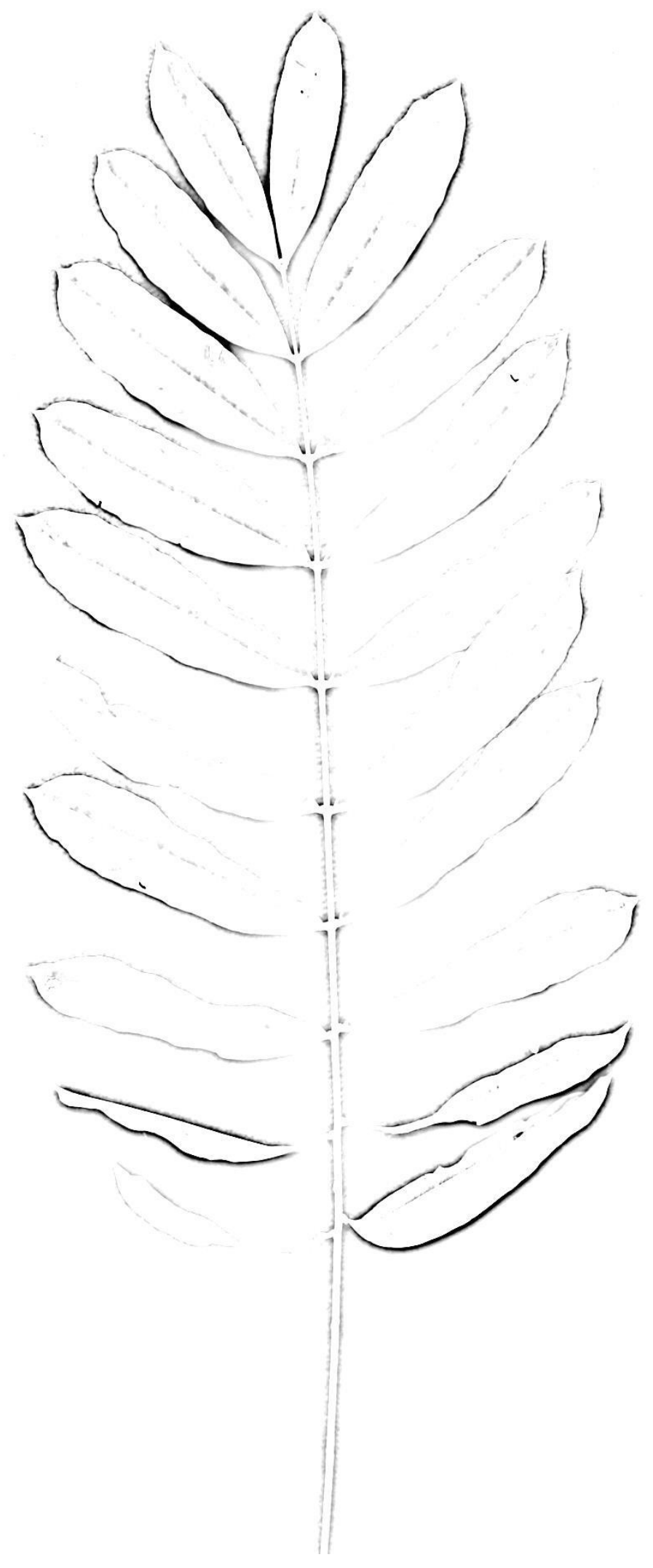


Álvarez R, Encina A, Hodalgo NP (2008) Pistacia therebinthus L. leaflets: an anatomical study. Plant Syst Evol 272:107-118

Bell AD, Bryan A (2008). Plant form: an illustrated guide to flowering plant morphology. 2nd edn. Timber Press, Portland

Bentley BL (1976) Plants bearing extrafloral nectaries and the associated and community: Interhabitat differences in the reduction of the herbivore damage. Ecology 57:815-820

Bentley BL (1977) Extrafloral nectaries and protection by pugnacious bodyguards. Annu Rev Ecol Evol Syst 8:407-428

Bentley BL, Elias TS (1983) The biology of nectaries. Columbia University Press, New York

Bharathan G, Goliber TE, Moore C, Kessler S, Pham T, Sinha NR (2002) Homologies in leaf form inferred from KNOXI gene expression during development. Science 296:1858-1860

Boas F (1913) Beiträge zur Anatomie und Systematik der Simarubaceen. Beiträge zur Botanische Centralblätter 29:303-356

Bory G, Maczulajtys DC (1990) Importance of foliar nectaries in the physiology of tree of heaven (Ailanthus glandulosa Desf. Simaroubaceae). Bull Soc Bot Fr 137(2-3):139-155

Bosabalidis A, Kofidis G (2002) Comparative effects of drought stress on leaf anatomy of two olive cultivars. Plant Sci 163:375-379

Cavalcante PB (1983) Revisão taxonômica do gênero Simaba Aubl. (Simaroubaceae) na América do Sul. Pub Avul Mus Para Emílio Goeldi. 37:1- 85

Castro MM, Machado SR (2005) Células e tecidos secretores In: Apezzato-Da-Glória B, CarmelloGuerreiro SM Anatomia Vegetal, 2nd edn, UFV, Viçosa, pp 179-203

Clayton, JW, Fernando ES, Soltis PS, Soltis, DE (2007). Molecular phylogeny of the Tree-of-Heaven family (Simaroubaceae) based on chloroplast and nuclear markers. Int J Plant Sci 168(9):13251339

Clayton JW (2011) Simaroubaceae. In: Kubitzki K (ed) The families and genera of vascular plants. Flowering plants, Eudicots. Sapindales, Cucurbitales, Myrtales, vol. X, Springer, Heidelberg, pp 408-423

Cronquist A (1944) Studies in the Simaroubaceae III. The Genus Simaba. Lloydia 7(1):81-92

Cronquist A. (1981) An Integrated System of Classification of Flowering Plants, Columbia University

Press, New York

Cruz R, Duarte M, Pirani JR, Melo-de-Pina GF. Deveoplment of leaves ando shoot apex protection in Metrodorea and related species (Rutaceae). Bot J Linn Soc. No prelo

Di Sapio O, Campagna MN, Rodriguez MV, Martinez ML, Gattuso S, Cortadi A,Gattuso M (2012) Parámetros micrográficos para la identificación de leño, corteza y hoja de Quassia amara L. (Simaroubaceae). B Latinoam Caribe P Medicinales y Aromáticas 11(2):172-187

Efroni I, Eshed Y, Lifschitz E (2010) Morphogenesis of simple and compound leaves: a critical review. Plant Cell 22:1019-1032

Ellis B, Daly DC, Hickey L J, Johnson KR, Mitchell JD, Wilf P, Wing SL (2009) Manual of leaf architecture. The New York Botanical Garden, New York

Engler A (1874) Simarubaceae. In: Martius CPF, Eichler AG (eds.) Flora brasiliensis 12(2):197-248 
Engler A (1931) Simaroubaceae. In Engler A, Prantl K. (eds.) Die natürlichen pflanzenfamilien, 2nd.edn 19a. Wiilhelm Engelmann, Leipzig, pp. 359-405

Erdtman G (1952) Pollen morphology and plant taxonomy. Almqvist \& Wiksell, Stockholm

Erdtman G (1986). Pollen morphology and plant taxonomy: angiosperms. Leiden. The Netherlands

Evert RF (2006). Esau's plant anatomy, 3rd edn, John Wiley \& Sons Inc, New Jersey

Fahn A (1979) Secretory tissues in plants. Academy Press, London

Fahn A. (1988) Secretory tissues in vascular plants. New Phytol 108:229-257

Fidalgo O, Bononi VLR (1989). Técnicas de coleta, preservação e herborização de material botânico. Instituto de Botânica, São Paulo

Franceschi V, Nakata P (2005) Calcium oxalate in plants: formation and function. Annu Rev Plant Biol $56: 41-71$

Francheschinelli EV, Yamamoto K (1993) Taxonomic use of leaf anatomical characters in the genus Simarouba Aubl. (Simaroubaceae). Flora. 188:117-124.

Francheschinelli EV, Yamamoto K (1995a) Distinctions among three Simarouba species. Syst Botany 23(4):479-488

Francheschinelli EV, Yamamoto K (1995b) Simaba docensis, a new Brazilian species of Simaroubaceae. Novon 9:345-348

Franceschinelli EV, Thomas WW (2000) Simaba guianensis subsp. huberi, a new Venezuelan taxon of Simaroubaceae. Brittonia 52(4): 311-314

Franklin GL (1945) Preparation of thin sections of synthetic resins and wood-resin composites, and a new macerating method for wood. Nature 155: 51

Friedman WEF, Moore RC, Purugganan MD (2004). The evolution of plant development. Am J Bot 91:1726-1741

Gadek PA, Fernando ES, Quinn C J, Hoot SB, Terrazas T, Sheahan MC, Chase AW (1996) Sapindales: Molecular delimitations ond infraordinal groups. Am J Bot 83:802-811

Gerlach D (1984) Botanische Mikrotechnik. Georg Thieme Verlag, Stuttgart

Hazel P, Winkinson FLS (1982) Leaf anatomy of Guta (L.) Ding Hou (Anacardiaceae). Bot J Linn Soc $86: 375-403$

Jadin F (1901) Contribution a` l'e'tude des Simaroubacées. Ann Sci Nat Bot 8:201-304

Johansen D (1940) Plant microtechnique. McGraw-Hill Book Inc, New York

Johansson J T (2013) and onwards. The Phylogeny of Angiosperms. Published online. http://angio.bergianska.se

Karabourniotis G (1998) Light-guiding function od foliar sclereids in the evergreen sclerophyll Phillyrea latifolia: a quantitative approach. J Exp Bot 49(321):739-746

Keeler KH, Kaul RB (1984) Distribution of defense nectaries in Ipomoea (Convolvulaceae). Am J Bot 71(10):1364-1372

Koptur S (1979) Facultative mutualism between weedy vetches bearing extrafloral nectaries and weedy ants in California. Am J Bot 66:1016-1020 
Kunth KS (1823) Simaroubea Decand. In:Humboldt FWHA, Bonpland AJA, Kunth KS. Nova Genera et Species Plantarum 4th edn,6:18,t514a-b.

Lacchia APS, Carmello-Guerreiro SM (2009) Aspectos ultra-estruturais dos canais secretores em órgãos vegetativos e reprodutivos em Anacardiaceae. Acta Bot Bras 23(2):376-388

Lusa MG, Appezzato-da-Glória B, Loeuille B, Bartoli G, Ciccarelli D (2014) Functional groups in Lychnophorinae (Asteraceae: Vernonieae) based on morphological and anatomical traits. Aust J Bot 62:150-163

Macedo EG, Potiguara RCV, Neto OR (2005) Anatomia foliar de Quassia amara L. (Simaroubaceae), uma espécie medicinal e inseticida. Bol Mus Para Emílio Goeldi sér Ciências Naturais 1(1) 9-18

Metcalfe C, Chalk L (1950) Anatomy of the dicotyledons, 2 vols, Clarendon Press, Oxford

Muntoreanu TG, Cruz RS, Melo-de-Pina GF (2011) Comparative leaf anatomy and morphology of some neotropical Rutaceae: Pilocarpus Vahl and related genera. Plant Syst Evol 296:87-99

Mori SA, Mattos Silva LA, Lisboa G, Coradin L (1989) Manual de manejo do herbário fanerogâmico, 2nd edn, Centro de Pesquisas do Cacau, Ilhéus

O'Brien TP, Feder N, McCully ME (1964) Polychromatic staining of plant cell walls by toluidine blue O. Protoplasma 59:368-373

Pirani JR Thomas WW Simaroubaceae In: Lista de Espécies da Flora do Brasil. Jardim Botânico do Rio de Janeiro. Disponível em: <http://floradobrasil.jbrj.gov.br/jabot/floradobrasil/FB1330>. Acesso em: 2 Fev. 2015

Purvis M, Collier D, Wall D (1964) Laboratory Techniques in Botany. Butterworths, London

Rachid M (1947) Transpiração e sistemas subterrâneos da vegetação de verão dos campos cerrados de Emas. FFLCH, Universidade de São Paulo 5:5-140

Radford AE, Dickison WC, Massey JR, Bell CR (1974) Vascular Plant Systematics. Harper and Row, New York

Rizzini CT, Heringer EP (1961) Undeground organs of plants from some southern brazilian savannas, with special reference to the xylopodium Phyton 17:105-124

Saraiva RCG, Barreto AS, Siani AC, Ferreira, JLP, Araujo RB, Nunomura SM, Pohlit A M (2002) Anatomia foliar e caulinar de Picrolemma sprucei Hook (Simaroubaceae). Acta Amaz 33(2):213220

Scatena VL, Giulietti AM, Borba EL, Van den Berg C (2005) Anatomy of Brazilian Eriocaulaceae: correlation with taxonomic and habitat using multivariate analyses. Plant Syst Evol 253: 1-22

Schemske DW (1980) The evolutionary significance of extrafloral nectar production by Costus woodsonii (Zingiberaceae): an experimental analysis of ant protection. Journal of Ecology 68:959-967

Silveira M (1989) Preparação de amostras biológicas para microscopia eletrônica de varredura. In: W. Souza (ed.): Manual sobre técnicas básicas em microscopia eletrônica, USP, São Paulo, pp 71-79

Simon MF, Pennington T (2012) Evidence for adaptation to fire regimes in the tropical savannas of the Brazilian Cerrado. Int J Plant Sci 173(6):711-723

Simpson MG (2010) Plant systematics. 2nd edn. Elsevier, Amsterdam

Sinha N (1999). Leaf development in angiosperms. Annu Rev Plant Physiol Mol Biol 50:419-416

Smith LG, Hake S (1992) The initiation and determination of leaves. Plant Cell 4:1017-1027 
Soiís SM, Ferrucci MS (2006) Comparative leaf morpho-anatomical studies of two South American species of Cardiospermum L. (Sapindaceae) with special reference to adaxial domatia. Blumea 51: $153-164$

Stace CA (1989) Plant taxonomy and biosystematics. 2nd edn. Cambridge University Press, Cambridge

Strittmatter CGD (1973) Nueva técnica de diafanización. Bol Soc Argent Bot 15(1):126-129

Thomas WW (1984) A new species of Simaba (Simaroubaceae) from Pará, Brazil, with a key to the species North of the Amazon River. Brittonia 36(3):244-247

Thomas WW (1985) The Simaba guianensis complex in Northern South America. Acta Amaz 15(12):71-79

Turner IM (1994) Sclerophylly: primarily protective? Funct Ecol 8:669-675

Weberling F, Leenhouts PW (1966) Systematisch-morphologische Studien an den TerebinthalesFamilien, n10, Abhandlungen der mathematische-naturwissenschaftelichen Klasse, Akademie der Wissenschaften und der Literatur Mainz, pp 1-90

Wheeler WC (2012) Systematics: a course of lectures. Wiley - Blackwell, Chichester

Ye Z (2002) Vascular tissue differentiation and pattern formation in plants. Annu Rev Plant Biol 53:183-202 
Capítulo 2

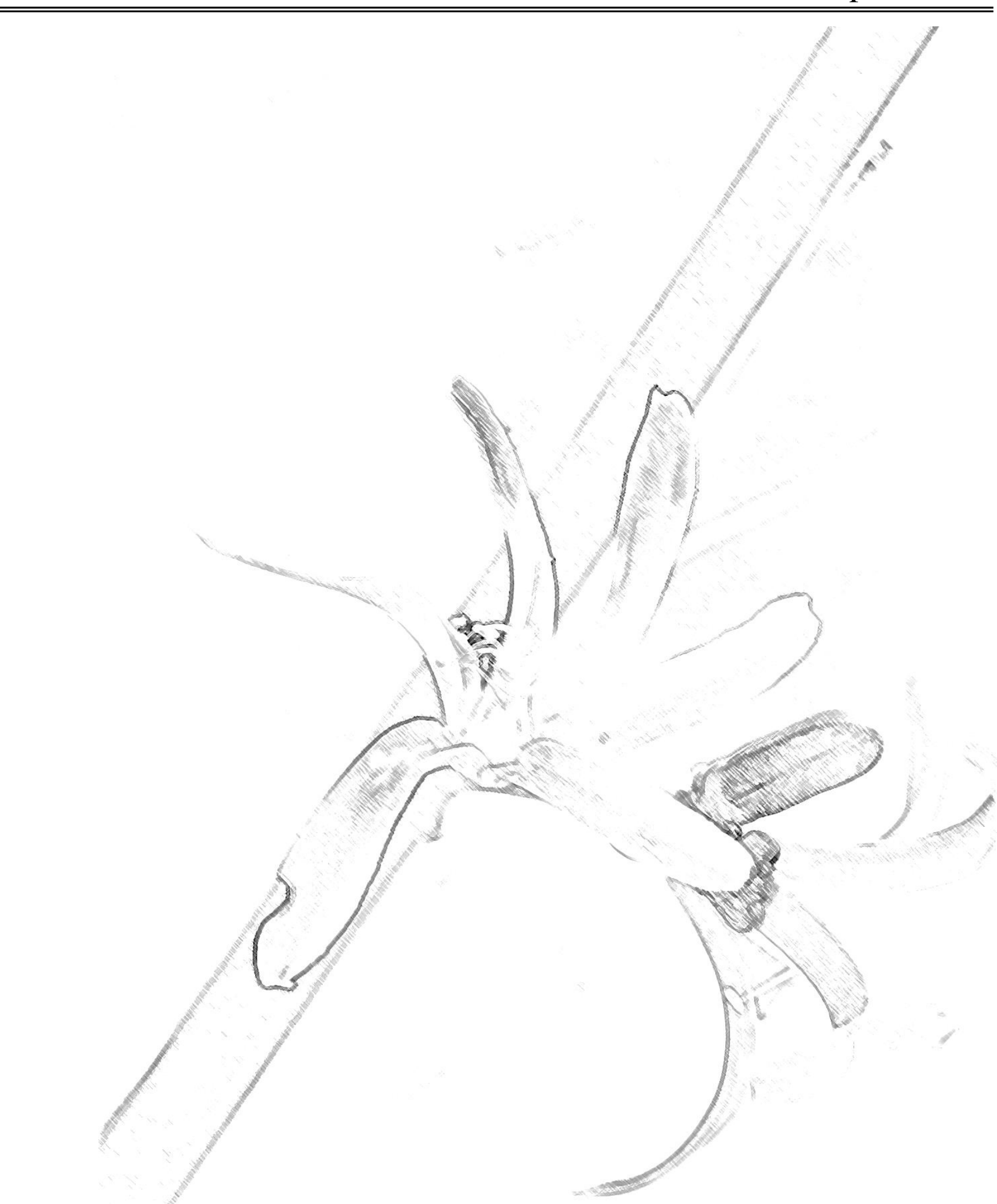




\title{
Flores de Simaba: estrutura e novidades anatômicas em espécies de $S$. sect. Floribundae e $S$. sect. Tenuiflorae (Simaroubaceae)
}

\author{
Gisele Alves ${ }^{1}$, Diego Demarco ${ }^{2} \&$ José Rubens Pirani ${ }^{1}$. \\ ${ }^{1}$ Laboratório de Sistemática Vegetal, ${ }^{2}$ Laboratório de Anatomia Vegetal, Departamento de \\ Botânica, Instituto de Biociências, Universidade de São Paulo. \\ Para correspondência: giselealves@usp.br
}

\section{Resumo}

Estudos descritivos da morfoanatomia floral foram feitos com poucas espécies de Simaroubaceae, não havendo registros de análises anatômicas das flores de representantes do gênero Simaba, o maior da família. Este é um grupo monofilético morfologicamente bem diversificado, com distribuição exclusivamente pantropical que apresenta flores com variações instigantes, suficientes para despertar grande interesse para estudos estruturais.

O presente trabalho apresenta a estrutura floral com enfoque comparativo realizado com espécies de duas das três seções de Simaba: S. sect. Floribundae e S. sect. Grandiflorae, ambas de ocorrência essencialmente extra-amazônica, e tradicionalmente distintas pelo tamanho da flor e grau de fusão do apêndice estaminal ao longo do filete. Utilizamos técnicas usuais em estudos anatômicos, com o intuito principal de prover um panorama de caracteres florais informativos para subsidiar a resolução dos problemas taxonômicos existentes no gênero e para serem usados em futura reconstrução de sua filogenia, viabilizando delinear e testar hipóteses sobre a evolução floral no grupo. Além da descrição e esquematização geral das características anatômicas florais do gênero, encontramos algumas novidades estruturais nas espécies analisadas, destacando-se a variação do merisma em diferentes flores de uma mesma inflorescência, as variações da sexualidade floral relacionadas com a esterilidade de órgãos (condição existente para outros membros da família, mas inédita em Simaroubaceae) e a conação parcial do androceu nas espécies de $S$. sect. Grandiflorae, constituindo características descritas aqui pela primeira vez em Simaba.

Palavras-chave: Anatomia floral, novidades estruturais, Sapindales. 


\title{
Simaba flowers: structure and anatomy novelties in some members of $S$. sect. Floribundae and S. sect. Tenuiflorae (Simaroubaceae)
}

\begin{abstract}
Few descriptive studies of floral morphoanatomy are available for species of Simaroubaceae species, with a complet lack of flower anatomical analyzes for the representatives of Simaba, the largest genus of the family. Simaroubaceae is a monophyletic group, though morphologically diversified, with pantropical distribution. The floral variations already described in the group stimulate a considerable interest for structural studies. This study presents the floral structure under a comparative approach, which was conducted with species of two from the three sections of Simaba: S. sect. Floribundae and S. sect. Grandiflorae, both mostly extra-Amazonian and traditionally distinct from each other by the flower size and the fusion degree of the staminal appendices along the filament. We aim to provide an overview of informative floral characters to support the resolution of taxonomic problems in the genus, and also to be used in an upcoming reconstruction of the phylogeny of Simaba, enabling to test hypotheses about its floral evolution.

Besides the description and layout of floral anatomical characters of the genus, we present some structural features that are novelties in te group, the most notable characters being: variation in merism among flowers of the same inflorescence; sexual floral variations related to the organs sterility (a condition known in several other members of Sapindales, though not yet recorded in Simaroubaceae), and the partial conation of the androecium in S. sect. Grandiflorae species.
\end{abstract}

Key words: Floral anatomy, structural novelties, Sapindales. 


\section{Introdução}

Existem poucos estudos detalhados da estrutura floral de Simaroubaceae. Os aspectos morfológicos fundamentais das flores da família foram tratados de modo detalhado nas monografias de Engler $(1874,1931)$ e a caracterização atualizada da morfologia floral da família e seus gêneros foram apresentadas por Clayton (2011). Nair \& Joshi (1958) afirmam que as flores da família exibem várias "tendências evolutivas", da dialissepalia à gamossepalia, bissexualidade à unisexualidade, diplostemonia à obdiplostemonia ou haplostemonia, apocarpia à sincarpia e redução do merisma floral. Postulam ainda que as flores unissexuadas do grupo seriam um estado derivado em relação às bissexuais. Simaroubaceae constitui uma família com alto potencial de estudo dada estas variações, que não são comuns nos grupos de Angiospermas. Tamanha variação pode indicar que a família possui uma diversificação relativamente recente.

Estudos descritivos da morfoanatomia floral foram feitos para poucas espécies da família (Saunders 1939; Nair \& Joseph 1957; Nair \& Joshi 1958, Narayan \& Sayeeduddin 1958). Dentre os estudos comparativos da estrutura floral de Simaroubaceae no contexto da sistemática evolução da ordem Sapindales, pode-se citar os estudos de Endress et al. (1983), Ramp (1988) e Bachelier \& Endress (2008). Analisando a estrutura do gineceu, Endress et al. (1983) mostraram que membros de Simaroubaceae e de outras famílias da ordem apresentam apocarpia combinada com a fusão pós gênita do ápice dos carpelos, estilete e estigma discutindo a implicação desse fenômeno na evolução da apocarpia secundária, bem como no desenvolvimento e dispersão dos frutos no grupo. Ramp (1988), também baseado na análise da estrutura do gineceu de 11 espécies e 10 gêneros da família, concluiu que Simaroubaceae representaria um grupo artificial, o que foi posteriormente corroborado por estudos anatômicos do pericarpo de 27 gêneros (Fernando \& Quinn 1992) e em seguida pela análise filogenética baseada em dados macromoleculares, que culminaram em uma recircunscrição da família, que passou a ser restrita aos membros da subfamília Simarouboideae (Fernando \& Quinn 1995). Bachelier \& Endress (2008), no estudo da estrutura floral de Kirkia (Kirkiaceae), grupo de posicionamento controvertido entre as Sapindales, concluíram que as características morfoanatômicas corroboram seu posicionamento mais próximo ao clado Anacardiaceae - Burseraceae, e não de Simaroubaceae, como evidenciado também nos estudos filogenéticos recentes.

O gênero Simaba possui flores bissexuadas reunidas em inflorescências terminais ou axilares do tipo panículas ou tirsóides com eixos glabros a pubérulos, ocasionalmente reduzidas a glomérulos axilares. São tetrâmeras ou pentâmeras, com cálice gamossépalo, pétalas livres, imbricadas, pubérulas a densamente pubescentes. O androceu é obdiplostêmone, composto de oito a dez estames com anteras dorsifixas e filetes dotados de apêndices laminares nos flancos, 
cujos tricomas podem estar entrelaçados em diferentes graus. A presença de um disco nectarífero junto ao ovário é marcante na maioria das Sapindales; contudo, em Simaba ele parece estar associado a um ginóforo geralmente bem conspícuo, cilíndrico, glabro a densamente pubescente. O gineceu é constituído por quatro ou cinco carpelos uniovulados, livres ao nível do ovário mas unidos pelos estiletes, com estigma capitado ou ligeiramente lobado. Os frutos são esquizocarpos constituídos por um a cinco mericarpos drupáceos, elipsoides a obovados, lenticulares ou fortemente alados, unisseminados (Engler 1874; Cavalcante 1983; Clayton 2011; Weberling 1989).

Não há estudos estruturais florais de representantes de Simaba disponíveis até o momento. No entanto, o fato de características florais serem a base da classificação infragenérica em três seções, vigente desde a proposta de Engler (1874), é indício da relevância que pode ter um estudo anatômico aprofundado da flor. Cronquist (1944) e Cavalcante (1983) detalharam melhor os caracteres distintivos destas seções, sobretudo o tamanho e formato do cálice e a extensão e tamanho da soldadura dos apêndices pilosos do androceu em relação ao filete. Cavalcante (1983) também destaca variações florais qualitativas e quantitativas que são úteis na delimitação de espécies do gênero. Entretanto, a circunscrição das seções pode ser complexa, uma vez que existe flagrante semelhança morfológica entre algumas espécies das duas seções extraamazônicas e por isso o limite entre elas é questionável.

Nesse contexto, analisamos a estrutura floral de quatro espécies de Simaba, pertencentes a duas das três seções do gênero: duas espécies de $S$. sect. Floribundae Engl. e duas espécies de $S$. sect. Grandiflorae Engl. (Fig. 1a - h) Estas seções se aproximam fundamentalmente pelo tamanho maior das flores e por sua distribuição extra-amazônica, enquanto $S$. sect. Tenuiflorae Engl. é composta por espécies quase exclusivamente amazônicas, com flores menores (Fig. 1x). Autores como Boas (1913) e Francheschinelli \& Yamamoto (1999) sugeriram que as espécies das seções extra-amazônicas deveriam ser unidas em uma única seção, assim como Clayton (2007), que na filogenia de Simaroubaceae apontou que os representantes de S. sect. Tenuiflorae constituem um grupo monofilético, enquanto que as espécies de $S$. sect. Floribundae e $S$. sect. Grandiflorae emergiram "misturadas" na análise.

O estudo comparativo detalhado da estrutura floral de espécies de Simaba pode fornecer subsídio adicional para aprimorar a taxonomia, seja na reavaliação das secções como na delimitação de espécies problemáticas. Pode também auxiliar em estudos de biologia floral e evolutivos no gênero, e pode ainda prover novos dados para estudos comparativos de estrutura floral de membros da família Simaroubaceae e da ordem Sapindales. 

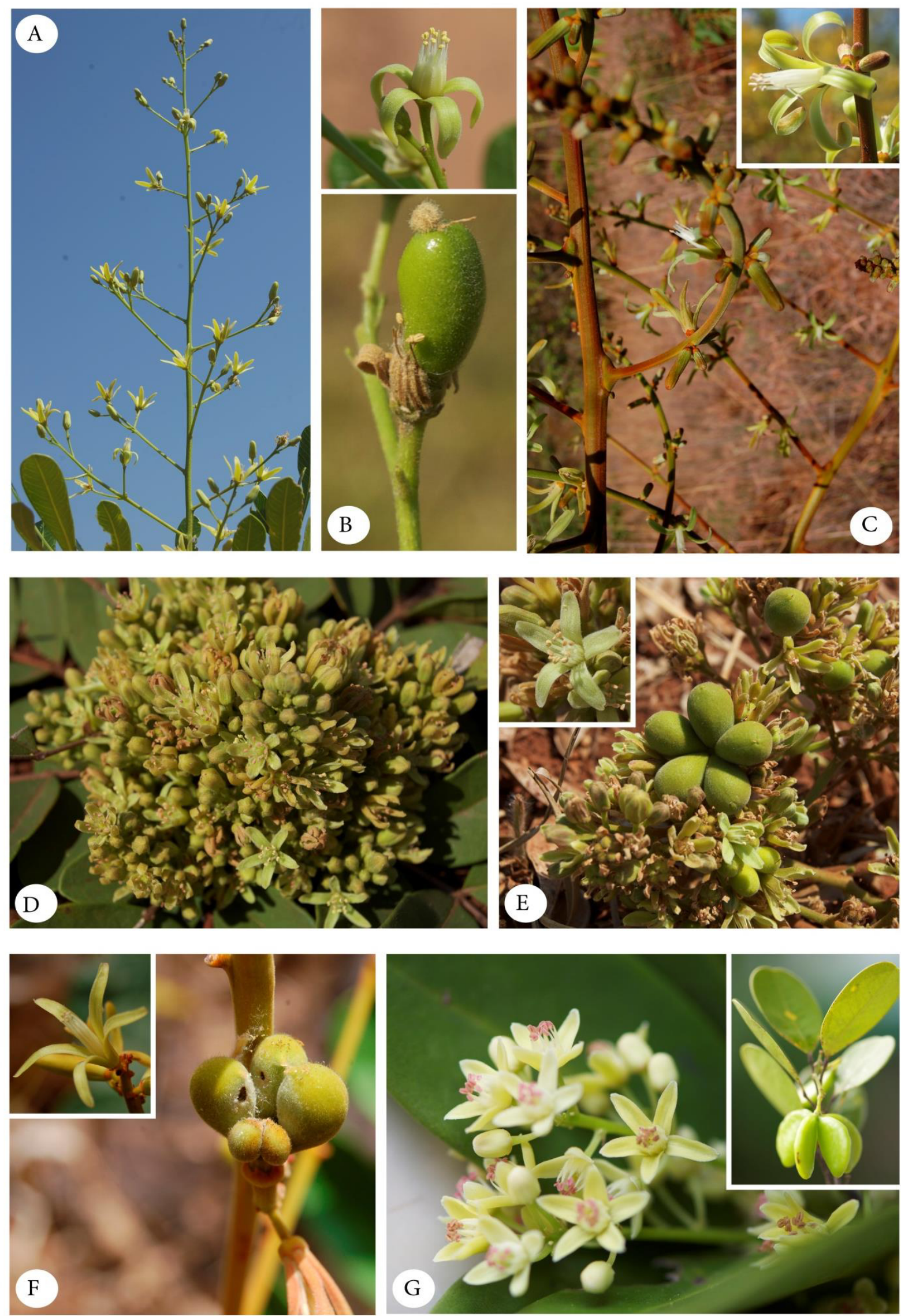
Figura 1. Morfologia geral de flor e inflorescência de Simaba: A. Inflorescência (uma panícula) de S. glabra; B. Fruto em desenvolvimento de S. glabra; flor em detalhe; C. Inflorescência (um tirsóide) de S. cedron; flor em detalhe; D. Inflorescência (cimeira densa) de S. suffruticosa; E. Flor em detalhe e frutos de S. suffruticosa; F. Flor em detalhe e fruto de S. cedron; G. Flores de S. obovata; fruto em detalhe. Fotos de M.F. Devecchi.

\section{Material e Métodos}

Para o presente estudo, foram selecionados dois representantes de Simaba sect. Floribundae (Simaba glabra Engl. e Simaba suffruticosa Engl.) e dois de S. sect. Grandiiflorae (Simaba cedron Planch. e Simaba trichilioides A. St.-Hil.). Os respectivos espécimestestemunhos (vouchers) encontram-se na tabela 1. Para obtenção do material utilizado neste estudo foram realizadas expedições de coleta por estados da região centro-oeste do Brasil, empregando-se métodos usuais de coleta e herborização de material botânico (Fidaldo \& Bononi 1989; Mori et al. 1989; Simpson 2010). Os espécimes-testemunho (vouchers) estão depositados no herbário SPF do Departamento de Botânica do IBUSP. Para complementação de algumas análises utilizamos alguns botões e flores em antese de espécimes disponíveis no acervo do herbário SPF. As observações de aspectos gerais das flores foram feitas sob estereomicroscópio Leica M125.

A análise anatômica foi baseada em secções de botões em pré-antese fixados em FAA, desidratados em série butílica ascendente e incluídos em Paralplast (Johansen 1940). Cortes seriados transversais e longitudinais foram obtidos em micrótomo rotativo LEICA RM2145 com espessura de 30 a $40 \mu \mathrm{m}$. As secções foram coradas com azul de astra e safranina (Gerlach 1984) e montadas com resina Permount. As análises realizadas em microscópio óptico Leica DM400B com câmera acoplada.

Algumas flores também em historresina (Historesin Leica), seguindo-se a técnica de Gerrits (1991), a fim de se obter secções mais finas e de melhor qualidade do gineceu. Nesse meio de inclusão, as flores foram seccionadas transversal e longitudinalmente com 10 a $14 \mu \mathrm{m}$ de espessura e as secções coradas com azul de toluidina 0,05\% (O’Brien 1964 ) em tampão acetato de sódio $0,1 \mathrm{M} \mathrm{pH} \mathrm{4,7.}$

Análises de microscopia eletrônica de varredura foram realizadas com material fixado, seco pelo método de ponto crítico, aderido ao suporte de alumínio e metalizado com ouro, conforme descrito em Silveira (1989). As imagens foram obtidas em microscópio ZEISS DSM 970. Os esquemas florais foram descritos da base do pedicelo ao ápice do botão floral. 
Tabela 1. Lista de vouchers das espécies de Simaba utilizadas nas análises.

\begin{tabular}{|c|c|c|c|c|}
\hline $\begin{array}{l}\text { Espécies agrupadas por } \\
\text { seção }\end{array}$ & Voucher & Vegetação & Estado (UF) & Herbário \\
\hline \multicolumn{5}{|c|}{ Simaba sect. Floribundae Engl. } \\
\hline S.glabra Engl. & Devecchi, M.F. 298 - III/2014 & Cerrado & MS & SPF \\
\hline S. suffruticosa Engl. & $\begin{array}{l}\text { Devecchi, M.F. } 213 \text { - XI/2013 } \\
\text { Devecchi, M.F. } 216 \text { - IX/2013 }\end{array}$ & $\begin{array}{l}\text { Cerrado } \\
\text { Cerrado pedregoso }\end{array}$ & $\begin{array}{l}\text { GO } \\
\text { GO }\end{array}$ & $\begin{array}{l}\text { SPF } \\
\text { SPF }\end{array}$ \\
\hline \multicolumn{5}{|c|}{ Simaba sect. Grandiflorae Engl. } \\
\hline S. cedron Planch. & Devecchi, M.F. 238 - IX/2013 & Cerrado alterado & GO & SPF \\
\hline S. trichilioides A.St.-Hil. & Devecchi, M.F. 226 - IX/2013 & Cerrado alterado & GO & SPF \\
\hline
\end{tabular}

\section{Resultados}

Morfologia

As flores das quatro espécies estudadas são pentâmeras (ocasionalmente tetrâmeras, em $S$. glabra e S. trichilioides), hipóginas, diclamídeas heteroclamídeas. O cálice é actinomorfo, gamossépalo, distalmente pentalobado (ocasionalmente tetralobado nas duas espécies supracitadas), de coloração creme-esverdeada e com tricomas simples e eretos em ambas as faces. A corola é actinomorfa com cinco pétalas livres de prefloração imbricada e coloração cremeesverdeada a creme-amarelada, com tricomas simples, adpressos a eretos.

O androceu é obdiplostêmone, composto por 10 estames, ou ocasionalmente oito em $S$. glabra e S. trichilioides. A obdiplostemonia é atestada pela posição antepétala dos carpelos, ou seja, o verticilo de estames alterno aos carpelos é o interno, e o externo é antepétalo. Os estames são monadelfos na base em flores de $S$. cedron e $S$. trichilioides, e totalmente livres em S. glabra e S. suffruticosa. Todas as espécies analisadas possuem filetes dotados de uma expansão laminar estreita, denominada apêndice estaminal. O grau de união entre os apêndices de filetes adjacentes varia entre as espécies, geralmente formando um tubo de extensão variada ocupando parte da metade proximal, estando livres nas demais porções (Fig. 2a). No nível em que os filetes estão bem individualizados, os apêndices mostram-se coerentes uns aos outros por um leve entrelaçamento de tricomas, principalmente em S. trichilioides (Fig. 2b).

O gineceu é pentacarpelar em todas as espécies analisadas (inclusive nas flores tetrâmeras), com ginóforo intensamente revestido por tricomas adpressos a eretos (Fig. 2f). Os carpelos são protuberantes dorsalmente acima do nível da base do estilete sendo, portanto, anacrostílicos (Fig. 2c); antepétalos, peltados e conatos uns aos outros por uma curta extensão na base dos ovários, 73 
sendo livres distalmente até a região de transição para o estilete, onde são posgenitamente unidos até a base do estigma. Este é capitado em S. cedron e S. trichilioides e ligeiramente pentalobado em S. glabra e S.suffruticosa (Fig. 2g, h). Há um único óvulo por lóculo de placentação axilar, síntropo, bitegumentado, onde o tegumento externo não recobre o interno.

\section{Anatomia}

Os esquemas elaborados das secções transversais foram apresentados de acordo com sua altura no corte longitudinal (Fig. 3a). No pedicelo o estelo é do tipo eustelo sendo formado por um cilindro central composto por múltiplos feixes fundamentais que circundam uma medula parenquimática (Fig. 3b). Na base do receptáculo observam-se os traços do cálice e a separação entre o ciclo de sépalas e os tecidos que constituem o estelo do eixo floral (Fig. 3c). Um único traço diverge do estelo e se ramifica em três traços que vascularizam cada sépala, deixando uma única lacuna no estelo do eixo floral (Fig. 3d), podendo se ramificar novamente em cinco traços na base de cada sépala em $S$. cedron e $S$. trichilioides Acima do nível de divergência dos traços do cálice, observam-se os traços das pétalas, que também deixam uma única lacuna no estelo do eixo floral e que se ramifica em três traços que vascularizam cada pétala. Cada sépala e pétala apresentam um ducto secretor na nervura central e demais nervuras de maior calibre (Fig. 4a). No nó seguinte são encontrados os traços dos dois verticilos do androceu organizados radialmente, com um traço por estame (Fig. 3e). O primeiro verticilo de estames formado é antessépalo e o segundo é antepétalo. Em flores adultas, por outro lado, os estames antepétalos assumem uma posição mais externa, tornando-se obdiplostêmones. Cada estame possui um único feixe vascular que se mantém íntegro ao longo de todo o filete até o conectivo (Fig. 4b). Os apêndices são avascularizados e formados por uma projeção adaxial e lateral do filete, que é achatado na base e filiforme após a separação do apêndice. (Fig. 4c).

As anteras são bitecas, tetrasporangiadas e lateralmente justapostas (Fig. 3j;). A parede da antera é formada por uma epiderme unisseriada e uma camada de endotécio composto por células colunares, com espessamentos de parede secundária lignificada formando trabéculas (Fig. 4d, e). Os grãos-de-pólen são aparentemente triaperturados, sendo necessária análise de microscopia eletrônica de varredura para confirmação (Fig. 4f). 
Fig. 2. Morfologia geral de flores de Simaba: A. Androceu e gineceu (sobre um ginóforo) em S. cedron; notando-se os apêndices estaminais; B Androceu e gineceu (sobre um ginóforo) de S. trichilioides, a seta aponta o tubo formado pelo leve entrelaçamento dos tricomas dos apêndices estaminais; C. Base da flora de S. cedron, com o androceu parcialmente removido para expor o acúmulo do néctar na base do ginóforo revestido de tricomas; D. Estame com filetes apicalmente bipartidos em S. glabra; E. Estame de S. suffruticosa (MEV); F. Ginóforo e ovário densamente revestidos de tricomas em S. glabra (MEV); G. Estigma pentalobado em S. suffruticosa (MEV); H. Estigma capitado em S. cedron (MEV). Fotos (A. e C.) de R. Mello-Silva.

$\mathrm{Na}$ sequência, há um alongamento do entrenó que forma o ginóforo, o qual possui vascularização típica do eixo floral, exceto em S. trichilioides cujos feixes não formam um círculo, mantendo-se arranjados em associação aos traços estaminais com uma disposição irregular (Fig. 3f; 4g, h). É possível ver a presença de tecido nectarífero composto por 10 a 20 camadas de parênquima secretor ao longo de todo o ginóforo com vascularização constituída predominantemente por floema, derivado dos traços de estames (Fig. 5a). As células da epiderme do ginóforo nectarífero apresentam conteúdo fenólico (exceto em S. suffruticosa), e o néctar é liberado através de estômatos que se encontram em depressões (Fig. 5b, c), exceto em $S$. suffruticosa, onde se encontram no mesmo nível da epiderme.

O estilete é vascularizado por cinco feixes, cada qual correspondente ao feixe dorsal de cada carpelo. Na porção central do estilete observa-se um cordão de tecido transmissor de tubos polínicos formando um cômpito (Fig 5g). Os feixes do estilete se dividem em feixes menores no estigma que possui epiderme secretora papilosa (Fig. 5h).

$\mathrm{Na}$ porção basal do ginóforo, observa-se o complexo vascular do gineceu em formato pentagonal, que se ramifica originando dois feixes dorsais e um ventral por carpelo (Fig. 3f'). Na altura dos lóculos, observa-se na parede de cada ovário um grande feixe ventral (resultante da fusão dos feixes ventrais), um dorsal e diversos feixes dorso-laterais menores (Fig. 3g; 5d). A vascularização de cada carpelo se mantém independente ao longo de todo carpelo. O óvulo é crassinucelar e a calaza possui uma ampla expansão da terminação vascular (Fig. 5e). Muitas células da epiderme externa do tegumento externo e epiderme externa do tegumento interno possuem conteúdo fenólico ocorrendo em maior quantidade na região antirrafeal. Apenas em $S$. trichilioides foi visualizado também endotélio (Fig. 5f). 

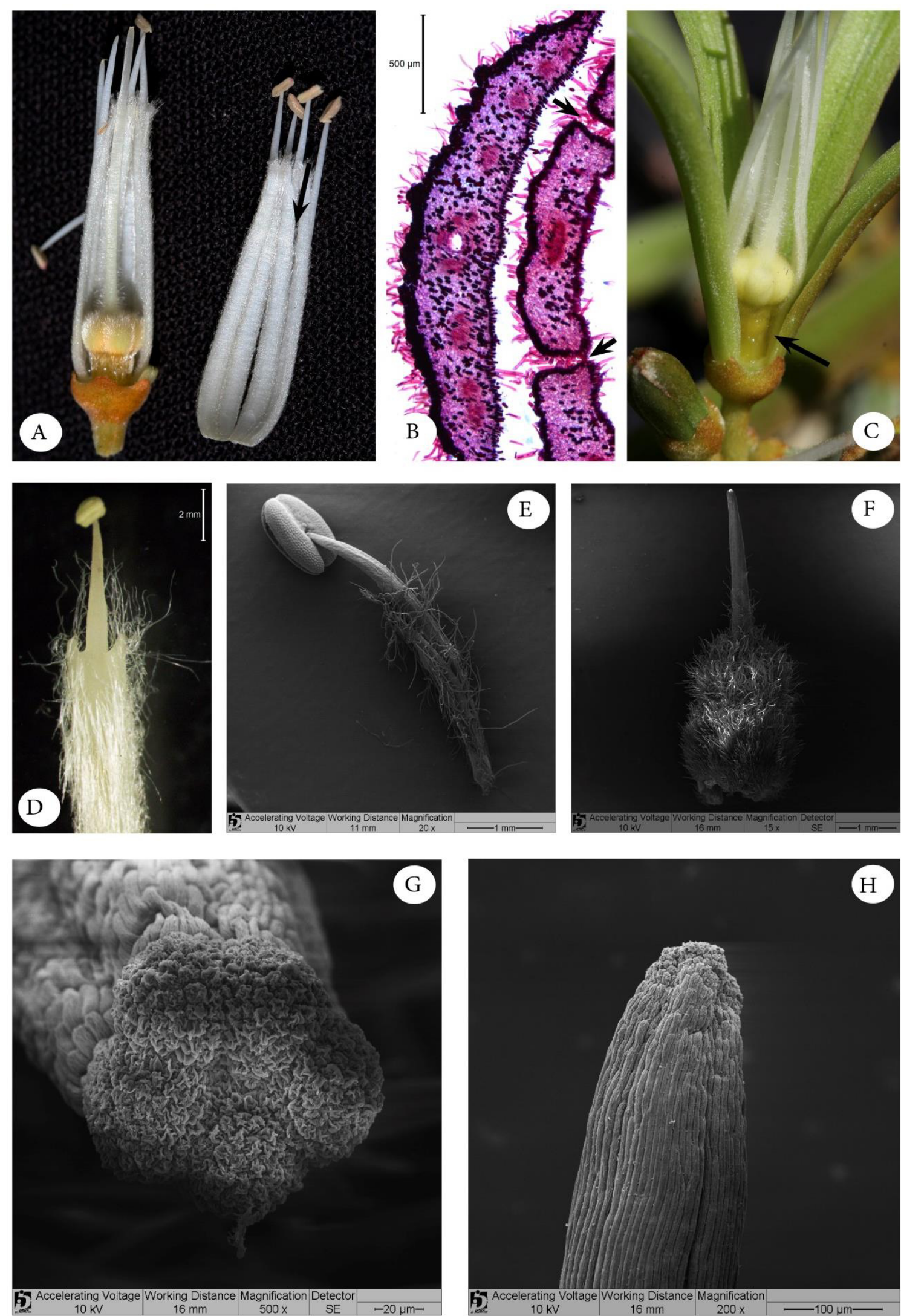


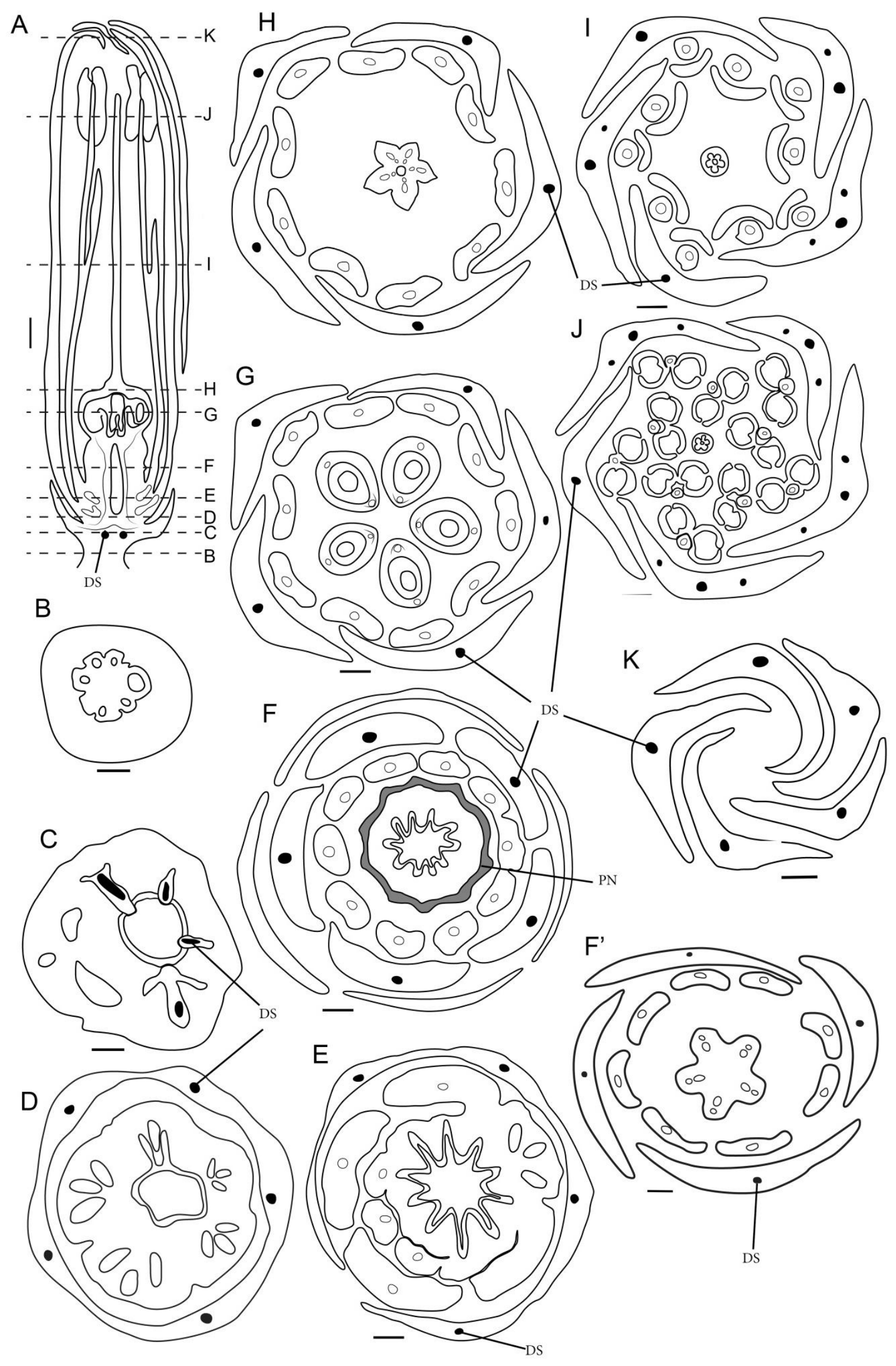


Fig. 3. Esquematização dos traços vasculares florais em Simaba cedron: A. Diagrama de secção longitudinal; B. Secção transversal evidenciando eustelo floral; C. Detalhe dos traços sepalares; D. Traços petalares; E. Traços estaminais; F. Detalhe da base do ginóforo; F'. Região basal do ovário; breve união congênita dos carpelos em $S$. trichilioides; G. Região mediana do ovário; H. Região apical do ovário; I. Região mediana do estilete; J. Região das anteras; K. Preforação imbricada. Abreviações: DS: Ducto Secretor; PN: Parênquima Nectarífero. Barras de escala: $500 \mu \mathrm{m}$.

Variação do merisma

Nas ocasionais flores tetrâmeras encontradas em algumas amostras de S. glabra e $S$. trichilioides, verificamos que uma das peças do cálice e uma da corola são constituídas de duas peças unidas, sendo o número de traços vasculares mantido como nas flores pentâmeras e incluindo o número de carpelos (cinco); com os estames ocorre a redução em número (de dez para oito), mas com os traços dos estames perdidos também mantidos (Fig. 4a).

\section{Dimorfismo sexual}

Um dos resultados mais instigantes desta análise foi encontrar evidências de ocorrência de flores unissexuadas em Simaba. Em S. suffruticosa constatamos a presença de flores exibindo estiletes de tamanhos diferentes em flores de uma mesma inflorescência. $\mathrm{Na}$ análise de microscopia eletrônica de varredura, bem como na análise anatômica, foi possível verificar que as flores cujos estiletes eram curtos possuíam todos os óvulos abortados (Fig. 6 a - d), constituindo assim um pistilódio.

\section{Discussão}

Os aspectos gerais da morfologia floral de Simaba aqui reportados são condizentes com as poucas descrições existentes na literatura do gênero (Engler 1874, 1931; Boas 1913; Cronquist 1944; Cavalcante 1983; Pirani 1987a, b). Contudo, o presente estudo estrutural provê algumas correções e grande aprimoramento. Embora não tenhamos dado aqui ênfase detalhada na vascularização floral, podemos elucidar que grande parte dos padrões observados em Simaba diverge pouco dos registrados em famílias próximas, como Rutaceae, Anacardiaceae, Kirkiaceae e gêneros próximos (Ramp 1988; El Ottra et al. 2013, Pirani et al. 2010; Bachelier \& Endress 2008; Endress \& Matthews 2006). Os pontos divergentes mais notáveis se referem ao merisma e sexualidade florais. Em Simaba se mantêm os traços condizentes à pentameria mesmo nas flores ocasionais com redução do número de peças nos verticilos corolino e estaminal. 
Fig. 4. Flores de Simaba: secções histológicas. A. Secção na altura da base do androceu e do ginóforo de $S$. glabra; a seta mostra ductos secretores na nervura das sépalas e pétalas; B. Filete de S. glabra, mostrando o feixe vascular; C. Secção numa porção distal da flor de S. glabra; notar quatro pétalas (uma delas resultante da união de duas) e oito filetes com apêndices avascularizados na forma de projeções laterais laminares que se separam na região distal dos filetes; no centro o estilete pentalobado, cm cinco feixes vasculares; D, E. Anteras de S. cedron e S. glabra; em D. notar células com conteúdo fenólico e em E. o endotécio com espessamentos evidentes na parede; F. Grãos-de-pólen em S. suffruticosa; G, H. Feixes arranjados em associação aos traços estaminais com disposição irregular em $S$. trichilioides.

Observamos em espécies de Simaba a ocorrência ocasional de flores tetrâmeras e até mesmo hexâmeras (S. salubris). A condição tetrâmera já havia sido reportada anteriormente no gênero (e.g. Engler 1874; Cronquist 1944) e, juntamente com a hexameria, tem sido reportada também para diversos grupos em Sapindales e outras Angiospermas (Pirani 2004; Pirani et al. 2010). Neste trabalho verificamos que a tetrameria encontrada em S. glabra e S. trichilioides não é completa: diferente do que ocorre em flores de outros gêneros da família, como Brucea, Castela e Soulameae (Nair \& Joshi, 1958; Ramp 1988). Estas espécies apresentam cinco sépalas ou a união parcial de duas sépalas e cinco carpelos, sendo estruturalmente flores pentâmeras com fusão de duas pétalas e a supressão na formação de estames.

Estas modificações podem estar relacionadas às variações da expressão dos genes, como analisado no modelo ABC (Coen \& Meyerowitz 1991), um dos principais avanços para o entendimento da evolução com estudos genéticos em Arabidopsis e Anthirrium. Segundo os autores, a expressão dos genes da classe A é relacionada com a formação de sépalas, enquanto os da classe B, em conjunto com os da classe A, expressam a formação das pétalas. Os genes da classe $\mathrm{C}$ em conjunto com os da classe $\mathrm{B}$ formam os estames e finalmente o gene $\mathrm{C}$ expressa isoladamente a formação dos carpelos. Posteriormente maiores estudos foram realizados e outras classes gênicas adicionadas (classe D determina formação de óvulos e classe E com genes atuando na expressão dos demais, sendo os genes SEP cofatores de ABC) (Cronk 2009). Nas flores de Simaba, a supressão ou adição dos verticilos petalares e estaminais precisam de maior investigação para averiguar qual gene está relacionado a estas variações nos verticilos florais. 


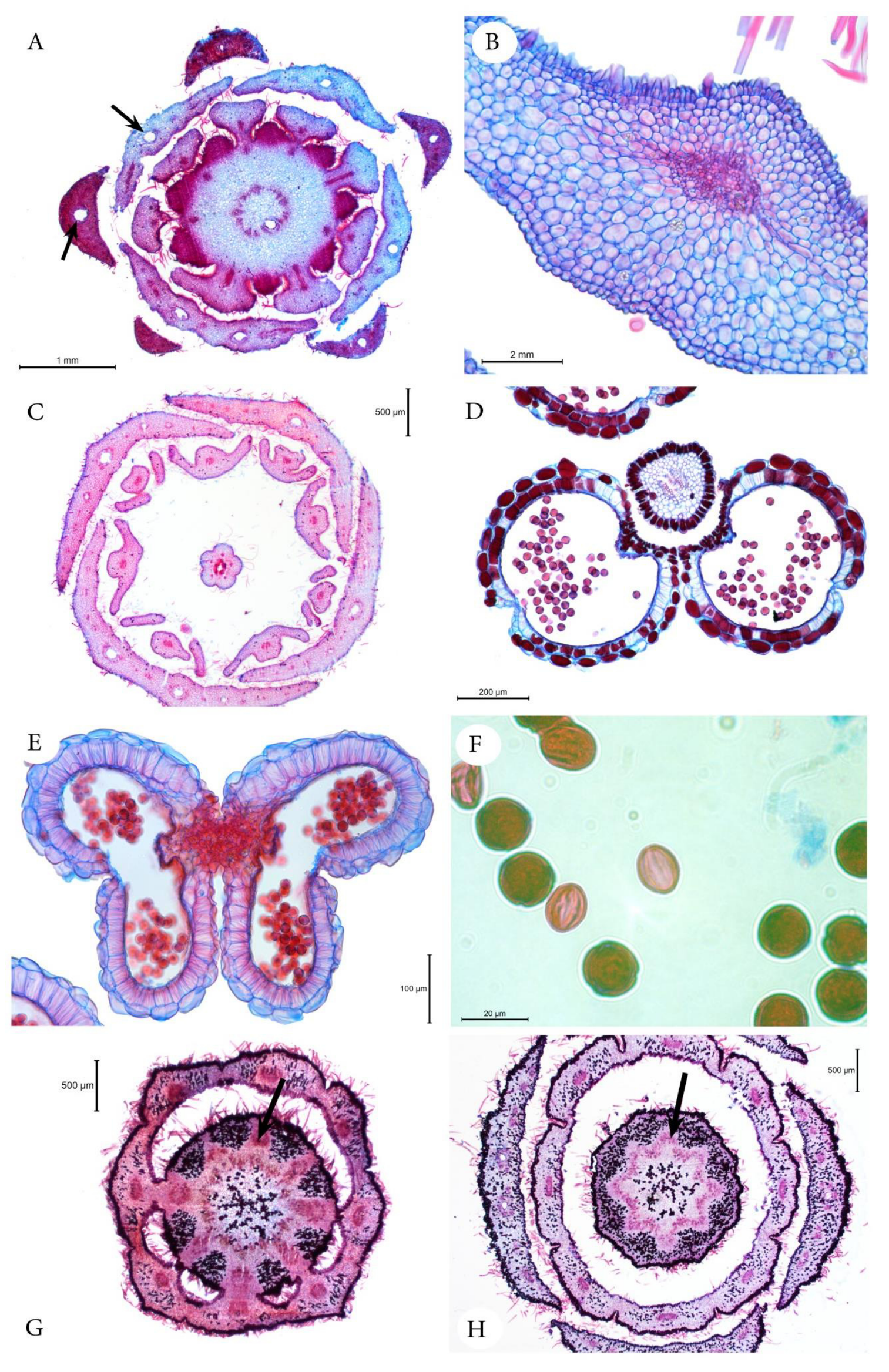


Fig. 5. Flores de Simaba: secções histológicas. A. Ginóforo de S. cedron, com o tecido nectarífero e vascularização por floema evidenciados; B, C. Estômatos localizados em depressões na epiderme do ginóforo de S. cedron; D. Cinco carpelos unidos mostrando feixes dorsal e ventral na porção basal do ovário, abaixo dos lóculos em $S$. trichilioides; E. Carpelo em secção longitudinal de S. cedron, mostrando óvulo crassinucelar com ampla expansão da terminação vascular calazal; F. Células com conteúdo fenólico e endotélio (seta) em S. trichilioides; G. Estilete de S. cedron, com feixes vasculares e cordão de tecido transmissor de tubos polínicos formando cômpito evidenciados; H. Estigma com epiderme secretora papilosa em S.cedron. Abreviações: TN : Tecido Nectarífero; CCF: Células com Compostos Fenólicos.

A obdiplostemonia é tida como um fenômeno "excepcional” (Weberling 1989) e este padrão é comumente reportado para as Sapindales (Eckert 1966), embora raro na vasta maioria das demais angiospermas (e.g. Weberling 1989). Nas flores estudadas de Simaba, o verticilo de estames antessépalos se desenvolve antes dos antepétalos. Entretanto, durante o desenvolvimento estes verticilos parecem trocar de posição, e os estames antepétalos ficam morfologicamente mais externos. Ronse Decreane \& Smets (1995) definiram este modo de desenvolvimento como obdiplostemonia secundária. Estes mesmos autores reportam este tipo de obdiplostemonia para representantes de Francoaceae e Greyiaceae, descrevendo o androceu como obdiplostêmone após o desenvolvimento da flor.

Existem controvérsias entre autores sobre como classificar o desenvolvimento e posicionamento dos verticilos do androceu. Endress (2010) afirma que a obdiplostemonia é sempre secundária, uma vez que os estames antessépalos sempre se desenvolvem primeiro, ou seja, não há inversão em relação às flores diplostêmones. Segundo o autor, nestes casos os estames antepétalos sofrem um retardo no desenvolvimento e o espaço para o desenvolvimento nos carpelos é maior nesta região. Contudo, ele conclui que a única forma de classificar a flor como obdiplostêmone é pela posição dos carpelos. Já Webberling (1989) afirma que flores obdiplostêmones apresentam carpelos antessépalos ou antepétalos, dependendo do desenvolvimento do segundo verticilo de estames (mais interno), ou seja, se os estames mais internos desenvolvem-se mais rápido ou mais lentamente haverá mais ou menos espaço para o desenvolvimento dos primórdios carpelares naquela disposição. Autores como Eckert (1966), Gelius (1967) e Klopfer (1973) afirmam que a diferença entre obdiplostemonia e diplostemonia seria o resultado de uma mudança na expressão dos estágios primordiais durante o desenvolvimento do androceu, e que a obdiplostemonia poderia ser vista como a expressão de uma tendência para os estames antepétalos tornarem-se reduzidos. 

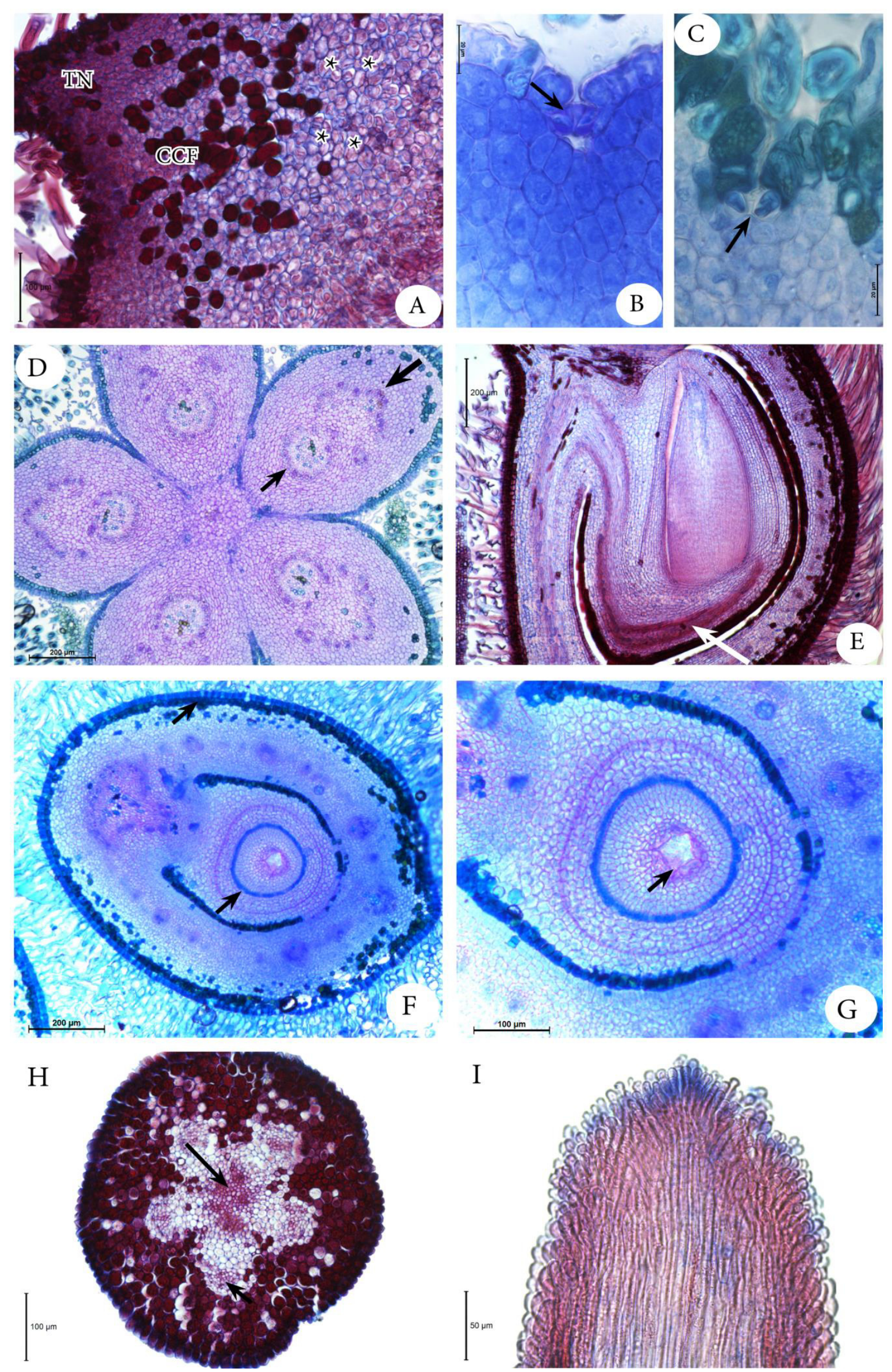

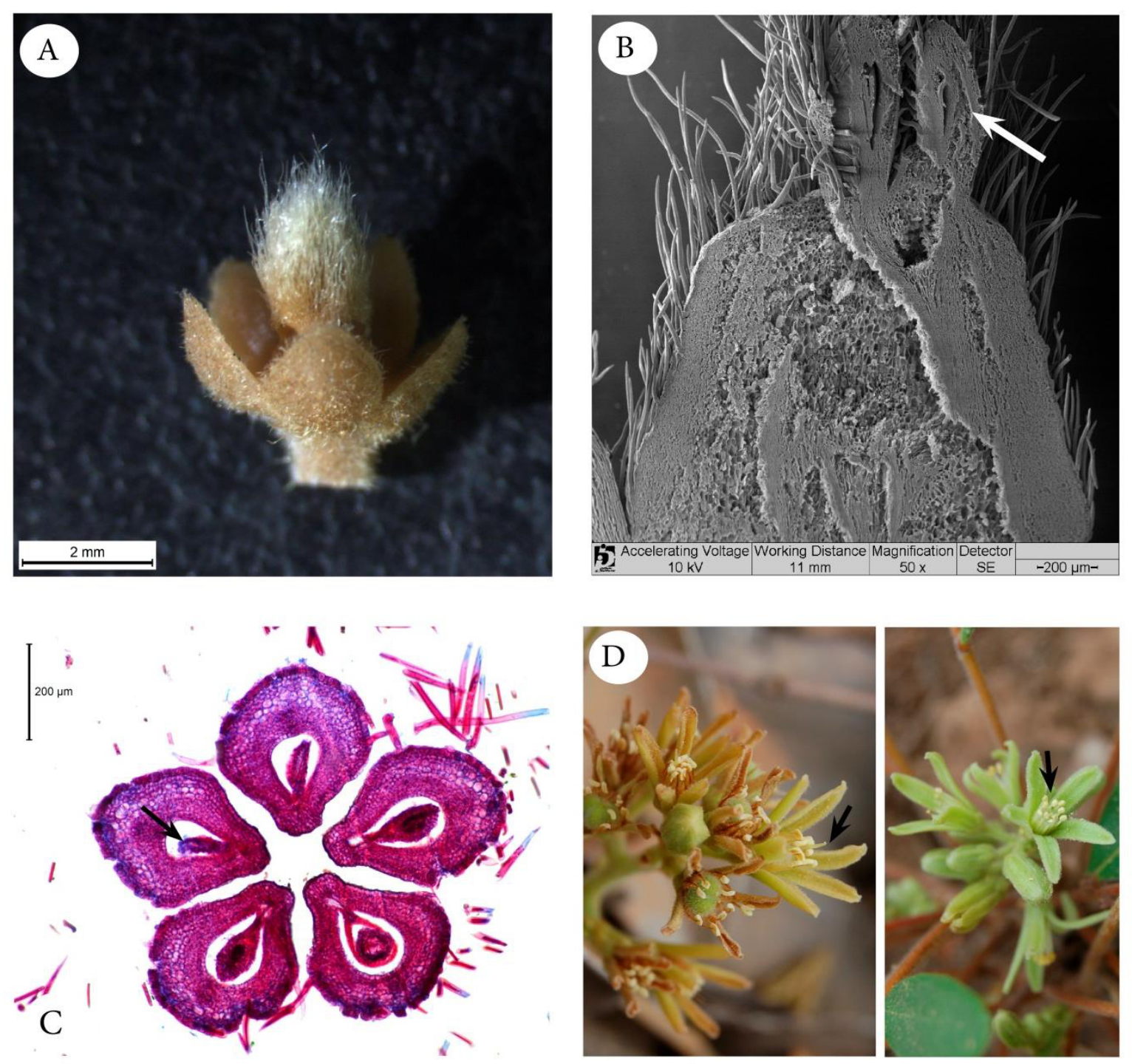

Fig. 6. Dimorfismo sexual em flores de Simaba suffruticosa. A. Flor com pistilódio; B. Ginóforo e pistilódio em secção longitudinal evidenciando óvulos abortados (MEV); C. Secção transversal de pistilódios evidenciando um óvulo abortado no interior de cada carpelo (microscopia óptica); D. Flores; Seta indica a presença de estilete acima do nível das anteras em uma flor e pistilódio em outra flor da mesma população. 
As espécies de Simaba apresentam androceu com obdiplostemonia secundária e carpelos antepétalos. Em membros da ordem Sapindales, a obdiplostemonia é comumente referenciada por ser tradicional na literatura dos grupos, mas em alguns estudos como o da tribo Ruteae de Rutaceae (Wei et al.2011), onde mesmo sendo visível o desenvolvimento inicial dos estames antessépalos no verticilo mais externo, o androceu é classificado como obdiplostêmone. Estudos envolvendo a análise do desenvolvimento floral forneceriam uma maior complementação para uma averiguação mais aprofundada sobre os padrões encontrados no androceu dos representantes deste grupo.

As flores de Simaba são registradas como bissexuadas em toda a literatura do gênero (e.g. Engler 1874, 1931; Cronquist 1944; Cavalcante 1983; Pirani 1987a,b). Entretanto, observamos que, assim como os representantes de Kirkia (Kirkiaceae; grupo anteriormente posicionado em Simaroubaceae e atualmente constituindo família à parte posicionada próximamente ao clado Anacardiaceae - Burseraceae), as flores analisadas de Simaba podem ser apenas morfologicamente bissexuadas e funcionalmente, unissexuadas. Atesta essa afirmação nossa observação de algumas flores com pistilos menores contendo apenas óvulos abortados em $S$. suffruticosa (Fig. 4a - c). O dimorfismo sexual em plantas hermafroditas deve estar relacionado à evolução da fertilização cruzada a partir de ancestrais autogâmicos, transições estas que surgiram de forma independente em diferentes números de linhagens, provendo oportunidades para busca de explicações da origem destes dois sistemas sexuais. Nosso achado em Simaba descortina agora a necessidade de investigação mais acurada da estrutura e biologia florais, para verificação de possível ocorrência de dicogamia, monoicia, dioicia ou poligamia (andromonoicia, androdioicia ou ginodioicia, por exemplo, Bawa \& Beach 1981; Barret 2002), neste gênero tradicionalmente reportado como hermafrodita. Será importante desenvolver pesquisas com plantas vivas, cultivadas ou em populações naturais, para detectar se ocorrem morfotipos que sejam estritamente unissexuais, ou seja, funcionalmente dioicos, ou um hermafrodita e outro feminino (ginodioicia) ou masculino (androdioicia). Em campo, foi verificado que em algumas populações floridas, é possível encontrar inflorescências quase inteiras com flores portando estiletes reduzidos (M.F. Devecchi com.pess) como observado em S. suffuticosa (Fig. 4d).

Essa evolução do conhecimento acerca da natureza sexual das flores tem ocorrido progressivamente em vários grupos de Sapindales nas últimas décadas. Muitas espécies inicialmente consideradas hermafroditas no grupo revelaram possuir flores unissexuadas, ao menos em parte. Em Meliaceae, por exemplo, após o estudo de Styles (1972), os gêneros da subfamília Swietenoideae e parte dos de Melioideae passaram a ser caracterizados como tendo exclusivamente flores unissexuadas, sendo as plantas monoicas ou dioicas; por outro lado, dois 
gêneros de Melioideae (Azadirachta e Melia) possuem flores uni e bissexuadas numa mesma inflorescência, tratando-se de espécies poligâmicas (Pennington \& Styles 1975).

Essa demora e dificuldade em interpretar adequadamente a sexualidade floral em Sapindales é reflexo da pequena diferença morfológica entre os tipos de flor. Por exemplo, em muitos casos a redução do androceu nas flores funcionalmente femininas é muito sutil, de modo que sem exame acurado elas parecem flores bissexuadas; no entanto suas anteras podem ser estéreis, seja por nunca se abrirem tornando o pólen indisponível (e.g. Cupania, Sapindaceae, Bawa 1977), seja por produzirem pólen inviável (e.g. vários gêneros de Meliaceae, Styles 1972), seja por não produzirem pólen algum (e.g. Anacardium, Mitchell \& Mori 1987; Schinus e Lithraea, Anacardiaceae, Barkley 1957, 1962). A andromonoicia de Anacardium é bem conhecida, sendo o pistilódio extremamente reduzido e sem lóculo diferenciado nas flores funcionalmente masculinas, distribuídas em meio às flores bissexuadas na mesma inflorescência (Mitchell \& Mori 1987). Judd et al. (2008) já caracterizam as flores de Simaroubaceae como unissexuais (em plantas monoicas ou raramente dioicas), mas com estaminódios e pistilódios frequentemente bem desenvolvidos. As distinções mais sutis entre flores de diferentes sexualidades numa espécie de Sapindales parecem ocorrer em Meliaceae, onde um pistilódio pode ser praticamente indistinguível do ovário funcional, e os estaminódios apenas levemente menores que os estames (Styles 1972). A situação em que as flores unissexuadas possuem órgãos com aparência idêntica aos de flores perfeitas pode ser denominada "dioicia críptica" (e.g. Eckhart 1999).

A distribuição topológica dos diferentes tipos florais também tem sido revelada: em certos gêneros, como Cedrela, as flores terminais de cada címula lateral e a flor do ápice do tirsóide são femininas, enquanto as flores laterais de cada címula são masculinas (Styles 1972; Gouvêa et al. 2008); em Melia a situação é similar porém as flores terminais são bissexuadas (Styles 1972). Cabe investigar se situação semelhante ocorre nos tirsos de Simaba e outras Simaroubaceae.

A dioicia funcional parece ser comum em muitos membros de Sapindales. Na floração de Dictyoloma (Rutaceae, Pirani 1989) e uma espécie de Cupania (Sapindaceae, Bawa 1977) ocorrem duas fases de flores masculinas intercaladas por uma de flores femininas, o que torna essas espécies xenógamas obrigatórias (dioicia funcional), embora morfologicamente monoicas. Em Kirkia wilmsii Engl .a dioicia funcional se expressa arquiteturalmente pela disposição das flores femininas nos ramos de ordem inferior nas cimeiras e tirsos, enquanto que as masculinas estão presentes nos ramos de ordem superior, com abertura sequencial na ordem de ramificação sucessiva nas inflorescências (Bachelier \& Endress 2008). Esta separação temporal da função feminina e masculina da inflorescência é caracterizada como heterodicogamia, fenômeno 
presente em 14 famílias de Angiospermas não relacionadas filogeneticamente. A maioria destas espécies documentadas é economicamente visada ou amplamente cultivada, cenário este que facilita a detecção desta forma de dimorfismo. A dificuldade no estudo para verificar a mudança sexual em populações de plantas dimórficas, que requerem monitoramento em longo prazo, além da mudança de sexo poder variar muito em tempo ocorrendo do dia para a noite ou uma única vez durante todo o período de floração, evidencia a necessidade de mais estudos sobre os sistemas sexuais de populações que apresentam variações funcionais nos sistemas reprodutivos (Renner 2001; Renner et al. 2007; Wang et al. 2012; Fukuhara \& Tokumaru 2013). Estudos com essas abordagens devem ser realizados com espécies de Simaba.

Cronquist (1981) afirmou que o disco em algumas Sapindales apresenta-se "modificado em ginóforo". Com efeito, agora demonstramos que o ginóforo de Simaba é nectarífero em toda extensão periférica, o que está em conformidade com a presença de nectário junto ao gineceu observada na vasta maioria das Sapindales e tida como provável sinapomorfia morfológica do grupo (Gadek et al. 1996). O nectário na ordem aparece geralmente como um disco anular ou ciatiforme, ocupando posição intraestaminal (extraestaminal em Sapindaceae, e.g. Cronquist 1981). Ginóforos são bem conhecidos em flores de outras famílias da ordem, como Rutaceae (e.g. El Ottra et al. 2013) e Meliaceae (Pennington \& Styles 1975), e sua ocorrência mais rara e esparsa no grupo parece indicar que se trata de um estado derivado que evoluiu independentemente nesses gêneros de famílias distintas.

A função nectarífera dos discos e ginóforos encontrados na flor da maioria das Sapindales tem sido aventada por muitos autores e comprovada em alguns gêneros. Gut (1966) defende essa função em Rutaceae com base na vascularização do disco predominantemente por feixes floemáticos. O disco de Pilocarpus pennatifolius Lem. (Rutaceae) foi descrito por Souza et al. (2005) como nectário de epiderme papilosa, com estômatos e tecido secretor de células diminutas, compartilhando poucas características com o observado em Simaba. A peculiaridade mais marcante do ginóforo deste gênero parece ser seu denso indumento, revestimento pouco comum em estruturas secretoras (Fig. 4a; $5 \mathrm{a}$ - c). A presença de tricomas longos concentrada em certas áreas de flores pode ser uma indicação de espaços irregulares nos botões florais, uma vez que os tricomas podem ser utilizados como materiais flexíveis de preenchimento, podendo ter função protetora contra herbívoros ou fatores físicos (por exemplo, a seca ou geada). Esses tricomas ocorrem de preferência na base ou ao redor dos carpelos, podendo desempenhar também um papel no desenvolvimento do fruto (Endress, 2008). Embora documentado para algumas famílias, como Hamamelidaceae, Cunoniaceae (Matthews \& Endress, 2002), Monimiaceae (Endress, 1980), Araliaceae (Endress, 2006), Moraceae (Berg, 1990) e também em 
Rutaceae (Zanthoxylum, Beurton 1994), a quantidade de indumento no ginóforo e ovário encontrados nas espécies de Simaba é muito grande. É possível supor que ele auxilie na redução da perda d'água, mantendo o volume de néctar presente na flor por um maior período.

O ovário das Simaroubaceae é tradicionalmente descrito como apocárpico ou sincárpico (Ramp, 1988). Na literatura de Simaba, a apocarpia tem sido apontada como secundária, dada a fusão pós-gênita dos carpelos no ápice dos ovários (Endress et al. 1983), estrutura que facilitaria a formação de cômpito. Neste trabalho observamos a presença de uma região congenitamente conata na base do ovário de todas as espécies analisadas, que embora curta, exclui a caracterização do gineceu do tipo apocárpico (Fig. 3f'). Este tipo de sincarpia de origem mista é denominado hemissincarpia, termo utilizado por Markgraf (1979) para descrever os frutos que se formam unidos apenas na base, como em espécies de Ochrosia Juss. (Apocynaceae s.s.). Ehrendorfer (1985) usou-o para descrever o gineceu de Apocynaceae s.s. e Asclepiadaceae (= Apocynaceae s.l.) e mais recentemente na descrição do gineceu de Mandevilla (Apocynaceae) por Gomes et al. (2008). Esta interpretação difere da empregada por Endress et al. (1983) que, mesmo reconhecendo regiões conatas na base dos carpelos de representantes da ordem Sapindales, a denomina como claramente apocárpica. No mesmo trabalho, Endress et al. (1983) apontam que este tipo de gineceu reúne as vantagens da apocarpia e da sincarpia. Endress (1982) discutiu como a condição "primitiva" apocárpica tem sido ultrapassada pela sincarpia nas Angiospermas, que proporciona vantagens como a distribuição mais regular dos tubos polínicos, intensificação da distribuição do pólen e aumento da diversidade de tipos de frutos dispersão na fase de frutificação. $\mathrm{O}$ mesmo autor afirma que nas Angiospermas existem tendências evolutivas alternativas, exibindo modificações da apocarpia ou sincarpia com diferenciações como o cômpito ou hiperestigma, constituindo métodos alternativos que compartilham algumas vantagens da habitual sincarpia. Assim como nas Apocynaceae hemissincárpicas, o gineceu das espécies de Simaba aparentemente apresenta as vantagens da apocarpia e sincarpia no misto arranjo de seu gineceu; entretanto, maiores estudos de ontogenia são necessários para corroborar este estado. Embora não haja referências deste tipo de gineceu misto em Sapindales, acreditamos que a hemissincarpia seria o termo que melhor descreve a condição de união e separação dos carpelos nos representantes analisados de Simaba.

Finalmente, a disposição dos estames apendiculados em torno do gineceu das espécies estudadas de Simaba, aliada à nossa constatação de que seu ginóforo é inteiramente nectarífero em sua região periférica permite elaborar hipóteses sobre a polinização. Uma vez que a epiderme do ginóforo é rica em substâncias fenólicas e o néctar secretado por estômatos, é possível assumir que a estrutura resultante da coerência dos filetes provida pelos apêndices formando um 
tubo estrito provavelmente atua restringindo o acesso ao néctar depositado no fundo do tubo, cujo acesso seria dificultado pela grande quantidade de tricomas no ginóforo. Desse modo, podese supor que a polinização seja realizada por insetos com longas probóscides por dentro do tubo estaminal para acessar o néctar. Os escassos dados sobre biologia da polinização em Sapindales ressaltam a necessidade de mais estudos nesta área para suportar este tipo de hipótese. 
Referências

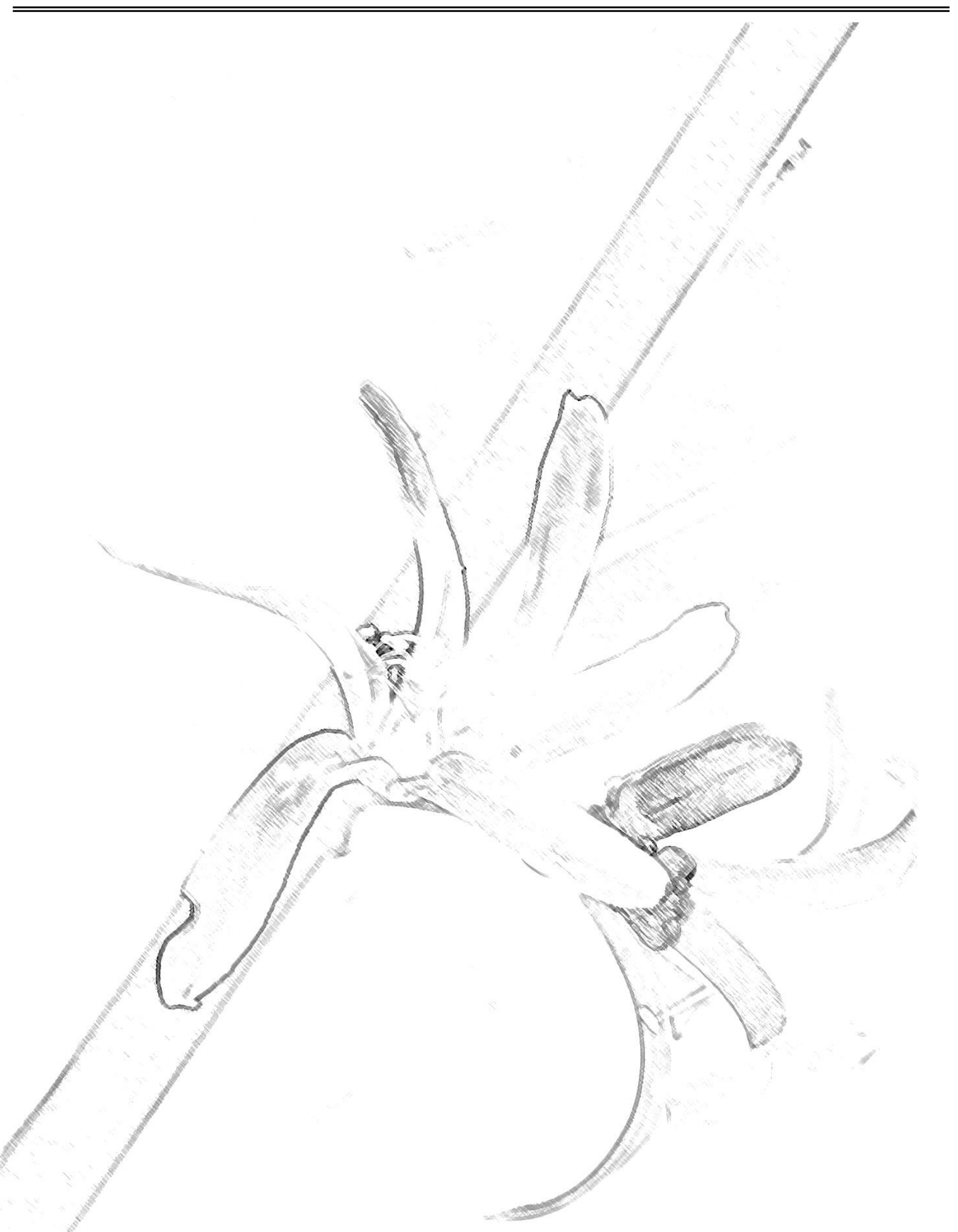


Bachelier, J.B. \& Endress, P.K. 2008. Floral structure of Kirkia (Kirkiaceae) and its position in Sapindales. Annals of Botany 102: 539-550.

Barret, S C H. 2002. The evolution of plant sexual diversity. Nature Reviews Genetics. 3: 274-284.

Bawa, K.S., 1977. The reproductive biology of Cupania guatemalensis Radlk. (Sapindaceae). Evolution. (31):52-63.

Bawa, K.S. \& Beach, J.H. 1981. Evolution of Sexual Systems in Flowering Plants. Annals of the Missouri Botanical Garden. 68(2):254-274.

Berg, C.C. 1990. Differentiation of flowers and inflorescences of Urticales in relation to their protection against breeding insects and to pollination.Sommerfeltia 11:13-24.

Beurton, C. 1994. Gynoecium and perianth in Zanthoxylum s. 1. (Rutaceae). Plant Systematics and Evolution. 189:165-191.

Boas, F. 1913. Beiträge zur Anatomie und Systematik der Simarubaceen. Beiträge zur Botanische Centralblätter 29:303-356.

Cavalcante, P.B. 1983. Revisão taxonômica do gênero Simaba Aubl. (Simaroubaceae) na América do Sul. Publicações Avulsas do Museu Paraense Emílio Goeldi 37:1- 85.

Clayton, J.W., Fernando, E.S., Soltis, P.S., Soltis, D.E. 2007. Molecular phylogeny of the Tree-ofHeaven family (Simaroubaceae) based on chloroplast and nuclear markers. International Journal of Plant Sciences 168(9): 1325-1339.

Clayton, J.W. 2008. Evolutionary history of Simaroubaceae (Sapindales): Systematics Biogeography and Diversification. Tese de doutorado. Universidade da Flórida.

Clayton, J.W. 2011. Simaroubaceae. In: Kubitzki, K. (ed.) The families and genera of vascular plants. Vol. X. Flowering plants. Eudicots: Sapindales, Cucurbitales, Myrtaceae. Springer. Berlin. p. 408423.

Coen, E.S. \& Meyerowitz, E.M. 1991.The war of the whorls: genetic interactions controlling flower development. Nature. (353):31-37.

Cronk, Q.C.B. 2009. The Molecular Organography of plants. 1ed. Oxford University. New York.

Cronquist, A. 1944. Studies in the Simaroubaceae. III. The Genus Simaba. Lloydia 7(1):81-92.

Cronquist, A. 1981. The evolution and classification of flowering plants. The New York Botanical Garden. New York.

Eckhart, V.M. 1999. Sexual dimorphism in flowers and inflorescences. In: Gender and Sexual Dimorphism in Flowering Plants. Geber, M.A., Dawson, T.E \& Delph, L.F. (eds), Springer-Verlag, Berlin. pp. 123-148.

Eckert, G. 1966. Entwicklungsgeschichtliche und blu"tenanatomische Untersuchungen zum Problem der Obdiplostemonie. Botanische Jahrbu"cher für Systematik 85:523-604.

Ehrendorfer, F. 1985. Sinopsis del reino vegetal: espermatófitos. In: Tratado de Botânica. Strasburger E. Ediciones Omeg., Barcelona. p.757-914.

El Ottra, J.H.L., Pirani, J.R. Endress, P.K. 2013. Fusion within and between whorls of floral organs in Galipeinae (Rutaceae): structural features and evolutionary implications. Annals of Botany 111: 821-837.

Endress, P.K. 1980. Ontogeny, function and evolution of extreme floral construction in Monimiaceae. Plant Systematics and Evolution. 134:79-120. 
Endress, P.K. 1982. Syncarpy and Alternative Modes of Escaping Disvantages of Apocarpy in Primitive Angiosperms. Taxon. 31(1):48-52.

Endress, P. K. 2006. Angiosperm floral evolution: morphological developmental framework. Advances in Botanical Research. 44:1-61.

Endress, P.K. 2008. The Whole and the Parts: Relationships Between Floral Architecture and Floral Organs Shape, and Their Repercussions on the Interpretation of Fragmentary Floral Fossils. Annals of the Missouri Botanical Garden. 95(1):101-120.

Endress, P.K. 2010. Synorganization without organ fusion in the flowers of Geranium robertianum (Geraniaceae) and its not so trivial obdiplostemony. Annals of Botany. 106:678-695.

Endress P.K., Jenny M. \& Fallen M.E. 1983. Convergent elaboration of apocarpous gynoecia in higher advanced angiosperms (Sapindales, Malvales, Gentianales). Nordic Journal of Botany 3: 293-300.

Endress, P.K. \& Mattews, M.L. 2006. First steps towards a floral structural characterization of the major rosid subclades. Plant Systematics and Evolution. 260:223-251.

Engler, A. 1874. Simarubaceae. In: Martius, C.P.F. \& Eichler, A.G. (eds.) Vol. 12. Flora brasiliensis. Frid. Fleischer. Leipzig. p. 197-248.

Engler, A. 1931. Simaroubaceae. In: Engler, A. \& Prantl, K. (eds.) ed. 2. 19a. Die natürlichen Pflanzenfamilien. Engelmann Leipzig. p. 359-405.

Fidalgo, O. \& Bononi, V.L.R. (coord.) 1989. Técnicas de coleta, preservação e herborização de material botânico. Instituto de Botânica, São Paulo.

Fernando, E.S. \& Quinn, C.J. 1992. Pericarp anatomy and systematic of the Simaroubaceae sensu lato. Australian Journal of Botany. 40:263-289.

Fernando, E.S., Gadek, P.A. \& Quinn, C.J. 1995. Simaroubaceae, an artificial construct: evidence from $r b c \mathrm{~L}$ sequence variation. American Journal of Botany 82:92-103.

Franceschinelli, E.V. \& Yamamoto, K. 1999. Simaba docencis, a new Brazilian species of Simaroubaceae. Novon. 9(3): 345-348.

Fukuhara, T. \& Tokumaru, S. 2013. Inflorescence dimorphism, heterodichogamy and thrips pollination in Platycarya strobilacea (Juglandaceae). Annals of Botany. 113(3):467-476.

Gelius, L. 1967. Studien zur Entwicklungsgeschichte an Blu"ten der Saxifragales sensu lato mit besonderer Beru"cksichtigung desAndroeceums. Botanische Jahrbu"cher für Systematik 87: 253303.

Gerlach, D. 1984. Botanische Mikrotechnik. Stuttgart, Georg Thieme Verlag.

Gerrits, P.O. 1991. The application of glycol methacrylate in histotechnology; some fundamental principles. Netherlands: Departament of Anatomy and Embryology State University Groningen.

Gomes, S.M., Kinoshita, L.S. \& Castro, M.M. 2008. Hemisincarpia e nectário apendicular enfocados através de ontogênese floral em Mandevilla velame (A. St.-Hil.) Pichon, Apocynoideae. Revista Brasileira de Botânica. 31(81-93).

Gouvêa, C.F., Dornelas, M.C., Rodriguez, A.P.M. 2008. Floral development in the tribe Cedreleae (Meliaceae, sub-family Swietenioideae): Cedrela and Toona. Annals of Botany. 101:39-48.

Gut, B.J. 1966. Beiträge zur Morphologie des Gynoeciums und der Blütenachse einiger Rutaceen. Botanisches Jarhbücher Systematische 85:151-247.

Johansen, D. 1940. Plant microtechnique. McGraw-Hill Book Inc. New York. 
Judd, W.S.; Campbell, C.S.; Kellog, E.A.; Stevens, P.F.; Donogue, M. J. 2008. Plant Systematics. A Phylogenetic Approach. Ed. 3. Sinauer Associates. Sunderlan.

Klopfer, K. 1973. Floral Morphogenese und Taxonomie der Saxifragaceae sensu lato. Feddes Repertorium 84:475-516.

Markgraf, F. 1979. Flora malesianae praecursores LIX. Apocynaceae V. Ochrosia, Neisosperma. Blumea. 25:233-247.

Matthews, M.L. \& Endress, P.K. 2002. Comparative floral structure and systematics in Oxalidales (Oxalidaceae, Connaraceae, Brunelliaceae, Cephalotaceae, Cunnoniaceae, Elaeocarpaceae, Tremandraceae). Botanical Journal of the Linnean Society. 140:321-381.

Mitchell, J.D. \& Mori, S.A. 1977. The cashew and its relatives (Anacardium: Anacardiaceae). Memories on the New York botanical garden (42):1-76.

Mori, S.A., Mattos Silva, L.A., Lisboa, G. \& Coradin, L. 1989. Manual de manejo do herbário fanerogâmico. Ed. 2. Centro de Pesquisas do Cacau, Ilhéus.

Nair, N.C., Joseph, T.C. 1957. Floral morphology and embryology of Samadera indica. Botanical Gazette 119: 104-115.

Nair, N.C. \& Joshi, R.K. 1958. Floral morphology of some members of the Simaroubaceae. Botanical Gazette 120: 88-99.

Narayan, L.L.\& Sayeeduddin, M. 1958. Floral anatomy of Simaroubaceae. I. J. Indian Bot. Soc. 37: 517-522.

O’Brien, T.P., Feder, N. \& McCully, M.E. 1964. Polychromatic staining of plant cell walls by toluidine blue O. Protoplasma 59:368-373.

Pennington,T.D. \& Styles, B.T. 1975. A generic monograph of the Meliaceae. Blumea.1975;22:419540.

Pirani, J.R. 1987a. Simaroubaceae. In: Spichiger, R. (ed.) Flora del Paraguay. Conservatoire et Jardin botaniques de la Ville Genève. Saint Louis, Missouri Botanical Garden.

Pirani, J.R. 1987b. Flora da Serra do Cipó, Minas Gerais: Simaroubaceae. Boletim de Botânica da USP 9: 219-226.

Pirani, J.R. 1989. Revisão taxonômica de Picramnia Sw. (Simaroubaceae) no Brasil. Tese (Doutorado). Universidade de São Paulo.

Pirani, J.R. 2004. Three new species of Galipea (Rutaceae, Galipeinae) from Brazil. Botanical Journal of the Linnean Society 144: 365-373.

Pirani, J.R., El Ottra, J.H. \& Menezes, N.L. 2010. Morfoanatomia da flor de cinco espécies de Galipea Aubl. e seu significado na evolução das flores tubulosas entre as Rutaceae neotropicais. Revista Brasileira de Botânica 32 (2): 301-318.

Ramp E. 1988. Struktur, Funktion und systematische Bedeutung des Gynoeciums bei den Rutaceae und Simaroubaceae. Doctoral Dissertation, University of Zurich.

Renner, S.S. 2001. How common is heterodichogamy? Trends in Ecology \& Evolution. 16(11):595597.

Renner, S.S., Beeken, L., Grimm, G.W., Kocyan, A. \& Ricklefs, R.E. 2007. The evolution of dioecy, heterodichogami, and labile sex expression in Acer. Evolution. 61(11)2701-2719.

Ronse-Decreane, L.P. \& Smets, E. I995. The distribution and systematic relevance of the androecial character oligomery. Botanical Journal of Linnean Society. (118):193-247.

Saunders, E.R. 1939. Floral Morphology: A New Outlook with Special Reference to the Interpretation of the Gynoecium, Vol. 2. Cambridge. Heffer \& Sons 
Sidman, R.L.; Mottla, P.A. \& Feder, N. 1961. Improved polyester wax embedding for histology. Stain Technology. 36:279-284.

Silveira, M. 1989. Preparação de amostras biológicas para microscopia eletrônica de varredura. In: W. Souza (ed.): Manual sobre técnicas básicas em microscopia eletrônica, USP. São Paulo. pp 71-79.

Simpson, M.G. 2010. Plant systematics. Ed. 2. Elsevier. Amsterdam.

Souza, A.; Mourão, K.S.M. \& Souza, L.A. 2005. Morfologia e anatomia do fruto e da semente em desenvolvimento de Pilocarpus pennatifolius Lem. (Rutaceae). Revista Brasileira de Botânica. 28(4):745-754.

Styles, B.T. 1971. The flower Biology of the Meliaceae and its Bearing on Tree Breeding. Silvae Genetica. Silvae Genetica. 21(5):175-182.

Wang, Z. 2012. Zang, P., Du, Q., He, H., Zhao, L., Ren, Y \& Endress, P.K. 2012.Heterodichogamy in Kingdonia (Circaeasteraceae, Ranunculales). Annals of Botany. (109):1125-1132.

Wei, L., Wang, Y.Z. \& Li, Z.Y. Floral ontogeny of Ruteae (Rutaceae) and its systematic implications. Plant Biology. (14):190-197.

Weberling, F. \& Leenhouts P.W. 1966. Systematisch-morphologische Studien an den TerebinthalesFamilien. Abhandlungen der mathematische-naturwissenschaftelichen Klasse, Akademie der Wissenschaften und der Literatur Mainz 10: 1-90.

Weberling, F. 1989. Morphology of flowers and inflorescences. Cambridge University Press. London. 
Considerações finais

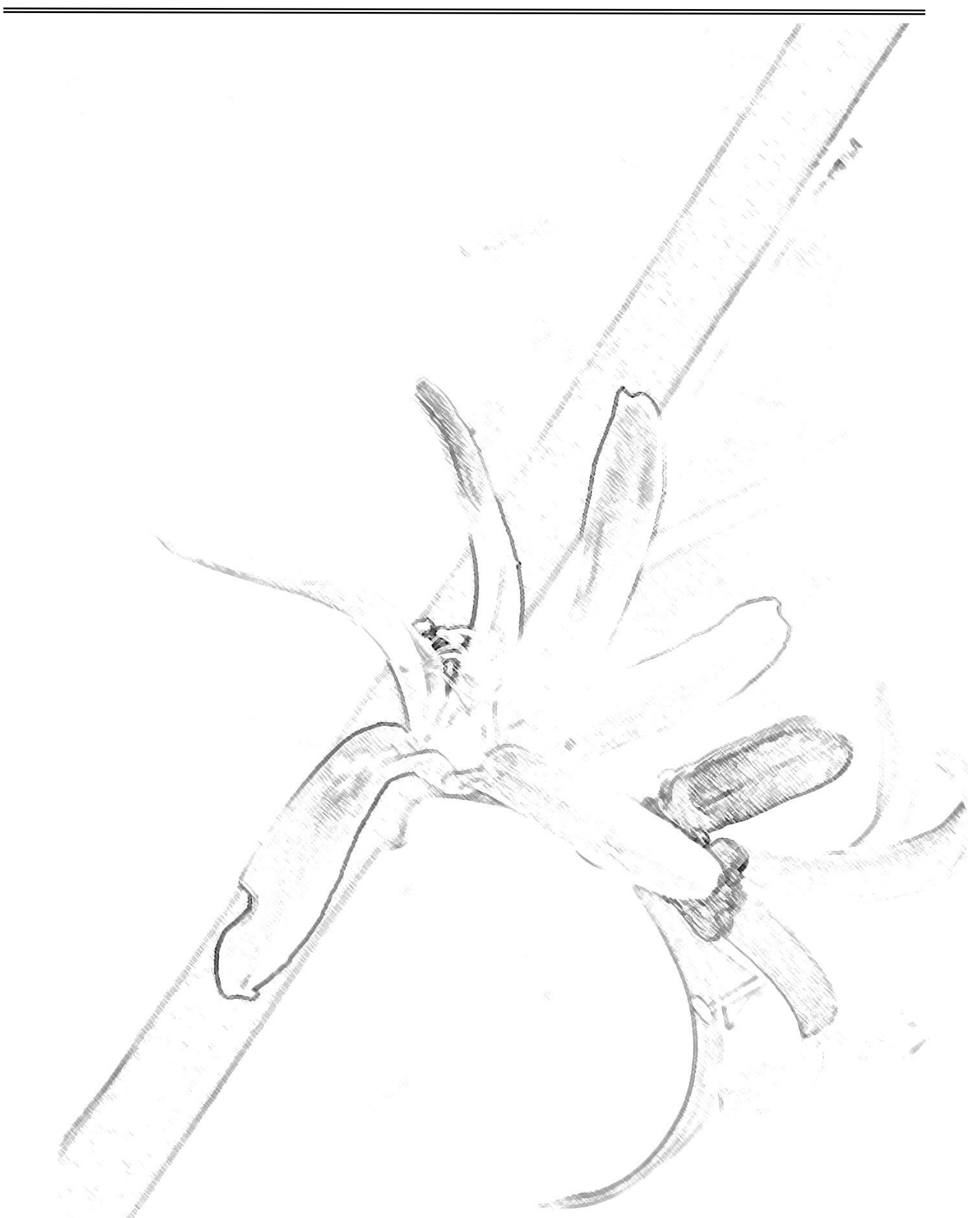


Neste trabalho realizamos análise estrutural foliar e floral de alguns membros do gênero Simaba (Simaroubaceae), buscando levantar dados para subsidiar a taxonomia e possibilitar análises evolutivas para o grupo. Visamos contribuir para o entendimento mais abrangente e características foliares e florais do gênero. Com a análise dos dados já disponíveis para o gênero e documentação da anatomia foliolar de mais da metade das espécies, troxemos características inéditas, como o padrão de venação dos folíolos que, embora não tenha apresentado variações infragenéricas, ainda não havia sido estudado; a caracterização dos nectários extraflorais presentes nos ápices dos folíolos e a descoberta de nectários extraflorais nas margens laminares e base foliolares; a congruência do tipo de esclereides presentes nas seções e a ausência de feixes vasculares acessórios na nervura central de todos os membros estudados da $S$. sect. Tenuiflorae. A análise da estrutura foliolar dos representantes de Simaba evidenciou caracteres que podem ser muito significativos para a taxonomia.

Os resultados obtidos na análise da morfologia e anatomia floral de duas espécies de $S$. sect. Floribundae e $S$. sect. Grandiflorae, seções cuja circunscrição é mais controvertida, mostraram alguns dados estruturais inéditos, uma vez que existem poucos sobre os representantes de Simaroubaceae e nenhum registro sobre espécies de Simaba. As flores de Simaroubaceae são relatadas na literatura como portadoras de uma considerável diversidade morfológica, podendo ser reflexo de um grupo de evolução recente. Neste trabalho, descrevemos e esquematizamos as secções longitudinais e transversais das flores de quatro espécies do gênero, encontrando como resultados principais: variação do merisma em diferentes flores de uma mesma inflorescência; variações da sexualidade floral relacionadas com a esterilidade de órgãos (condição existente para outros membros da família, mas inédita em Simaroubaceae) e a conação do androceu nas espécies de $S$. sect. Grandiflorae, que constituem características descritas aqui pela primeira vez no gênero, algumas delas controversas com o pouco existente na literatura. Estes resultados abrem muitas possibilidades de estudos futuros, que são necessários para investigação mais aprofundada destes caracteres visando ao entendimento da biologia e evolução do grupo. 